\title{
DESIGN INFORMATION QUESTIONNAIRE FOR A MODEL MIXED OXIDE FUEL FABRICATION FACILITY
} \\ P.O. Box 2351, 1200 Prospect Street, La Jolla, California 92038
}

May 1976

PREPARED FOR

ENERGY RESEARCH AND DEVELOPMENT AGENCY DIVISION OF SAFEGUARDS AND SECURITY

BROOKHAVEN NATIONAL LABORATORY UPTON, NEW YORK 11973 
INTRODUCTION

The model fuel plant described in this questionnaire is based on the proposed Westinghouse Anderson, S.C., plant and is typical of plants that will be constructed and operated in 1980-1990. A number of plant systems and procedures are uncertain. In these cases SAI judgment was used in describing relevant parameters in order to provide a complete model on which to design an inspection plan. The model plant does not, therefore, strictly represent any planned facility nor does it strictly represent the ideas of Westinghouse on plant design and material accountability.

This report is divided into two sections. The first section is the IAEA Design Information Questionnaire form that contains an outline of all information requested. Information is included on the form where space permits, otherwise a reference to Section II is given. Section II is a complete listing of design information organized according to the IAEA DIQ format. 


\section{SECTION I}




\section{INTERNATIONAL ATOMIC ENERGY AGENCY DEPARTMENT OF SAFEGUARDS AND INSPECTION}

\section{DESIGN INFORMATION QUESTIONNAIRE}

The purpose of this doeument is to oblain the lacility design information required by the Ageney in order to ofischaros its salcguarcs responsibilities. It will also wrve as o chcek list for examination of design infor. mation by Agency inspectorist. It, in any area, in. erffizient space is evailable odd turthar sheets to the extent neccosiary.

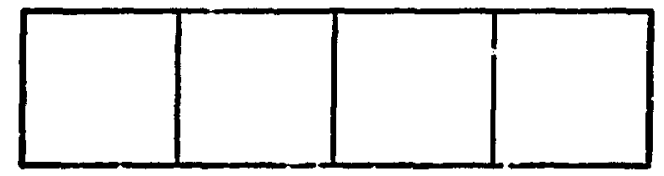

\begin{tabular}{|l|l|}
\hline \multicolumn{2}{|c|}{ IAEA USE ONLY } \\
\hline COUNTRY & \\
\hline COUNTRY OFFICER & \\
\hline TYPE & \\
\hline DATE & \\
OF INITLL DATA & \\
\hline VERIFICATION & \\
\hline LAST REVIEW & \\
AND UPDATING & \\
\hline & \\
& \\
& \\
\end{tabular}


ALL FACILITIES

\begin{tabular}{|c|c|}
\hline \multicolumn{2}{|c|}{ GENERAL INFONMATION } \\
\hline 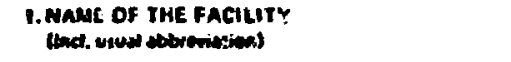 & A Mixed Oxide Recycle Fuels Plant (RFP) \\
\hline 2. LOCATION AND NOSTAL AODMESS & Southeast USA \\
\hline 5. CWNLA (legally eteonsitul & Company !! \\
\hline 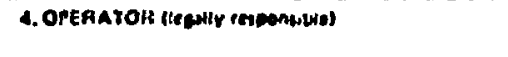 & Conpany U \\
\hline 5. OESCFir TIO:d (man frezuras enly) & $\begin{array}{l}\text { A fabrication facility utilizing a mixture } \\
\text { of urarium and plutonium oxide powders to } \\
\text { hanufacture fuel pellets and fuel rods for } \\
\text { higit water mocierated nuclear power reactors }\end{array}$ \\
\hline 6. ruRrose & Commercial Aanufacture \\
\hline 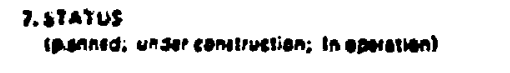 & Planned \\
\hline 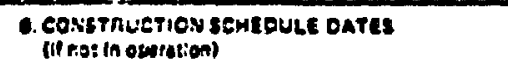 & \begin{tabular}{|l|l|l|} 
elconfleuslien & Commistioning \\
\end{tabular} \\
\hline & bincertain \\
\hline 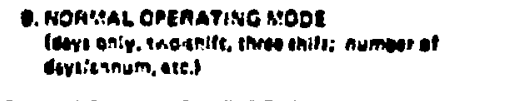 & $\begin{array}{l}\text { Three shifts per day, seven days per week } \\
\text { ?í days ner year minus scheduled shutdown }\end{array}$ \\
\hline 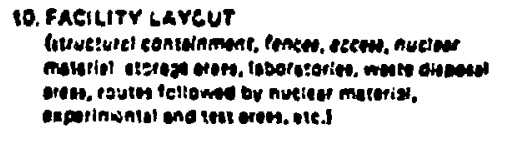 & onaminots attackto unoen aef. men. Figure 10.1 \\
\hline 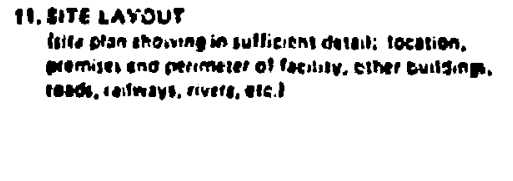 & 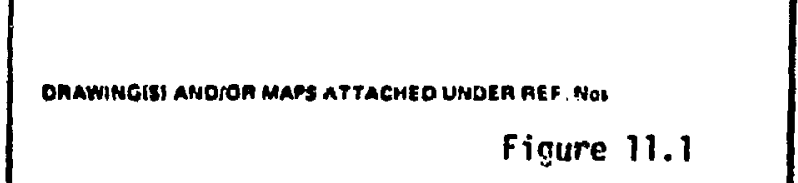 \\
\hline 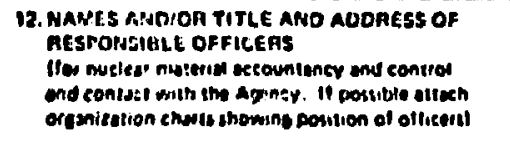 & $\begin{array}{l}\text { iuclear ibterials :ianager reporting to } \\
\text { ian: lianager }\end{array}$ \\
\hline
\end{tabular}


CONVERSION ANDIOH FUEL FABKICAIIUN PLANTS

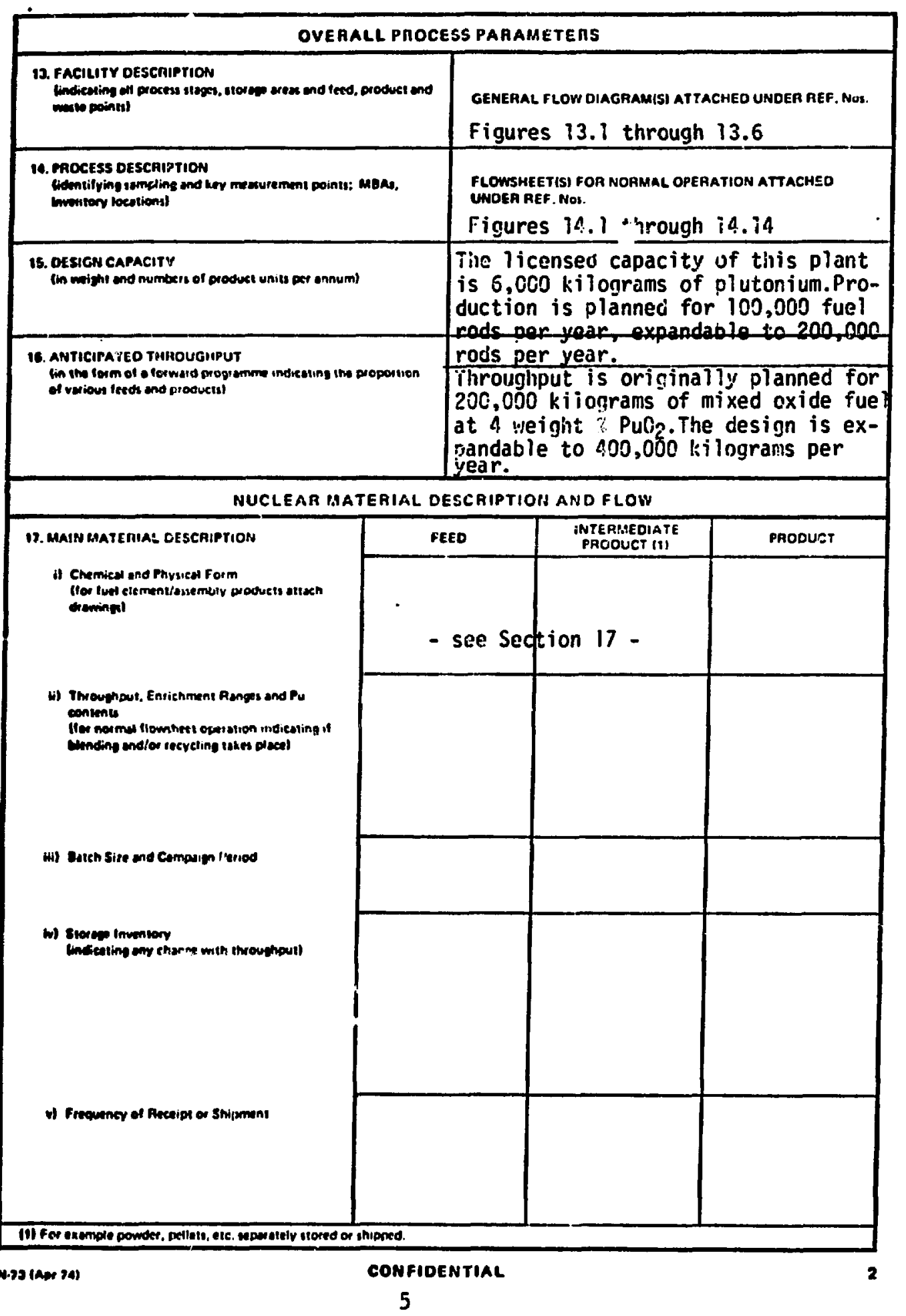




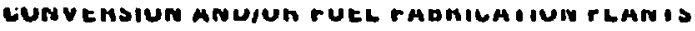

NUCLEAR MATE RIAL DESCAIPTION AND FLOW

19. WASTE MATERIAL (indicating major contributors; liquid or solid; range of constituents: entiehment reneand Pu content, include contaminated citulporment)

D) Storage Inventory Rang, Method and Frequency of Recovery/Disposd

19. container RS. packaging and storage AREA DESCRIPTIONS
1) source and form

See attachments, Figures 20.2 and 20.3 and Table 18.1.

SEPARATE NOTE TO BE ATTACHE O

describing for feeds, products and wat tet the type and sure of containers and pekeging used; method of stage; any special identification features.

See attachment, Table 19.1.

20. ReCYCle pRocesses

Ibrialiy describe any such processes giving source ans form of material. method of stor age, norms imintory. frequency of processing)

28. MEASUAEO DISCARDS ANO RETAINED WASTE

1) A st of input
See Section 20.

See Section 21.

CONFIDENTIAL

3

6. 
CONVERSIUN ANUIUK PUEL RAGHICAIIUN PLANIS

NUCLEAR MATERIAL DESCRIPTION AND FLOW

22. INVENTOAY

I) in-Process

fwithin plent end equipment during norme

cporstion: indicete quentity. form and main

becotiom and eny significent chengs with

time of throuchpell

v) Dther locations

fouentity. folm end focation of inventory not

clready apecilied)

See $i t \in m$ 17(iv) of this DIQ.

PLANT MaINTENANCE LECONTAMINATION, CLEAN.OUT
23. MAINTENANCE.

separate note to de attached

dercrituing plans and precedures and defining all aumpling ans key mesurement posints msocisted with:

i) notmal nient maintenance

ii) plont and equipment detontomingtion snd vibuequent nueles matetsal neovery:

(ii) plent and equipment clesn-out.

-

See Section 23.

PROTECTION AND SAFETY MEASURES

24. EASIC MEASURES FOR PHYSICAL PAOTECTION OF NUGLEAR Mitenial

See Section 24.

26. SPECIFIC HEALTH AND SAFETY RULES FOR INSPECTOA COMPLIANCE

(if extmive, attech seperataly)

See Section 25. 


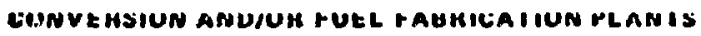

NUCLEAR MATERIAL ACCOUNTANCY

26. SYSTEM DCSCNIPTION

Girte description of the nuster moterid eccountency ivstem. the mothou of tecrthng and ieporting tecouniancy ojla ond eltiblithing moterial balances, Irecuency of moterial bevences, procectures tor eccount edjustment alter plent unventory. mistakes, elc., undar the following mading:

1) Comed
SPECIMEN FOIMS USED IN ALL PROCEOURES ATTACHED UNDER REF. NO.

See Section 26.

CONFIOENTIAL

5

8 


$$
[
$$




$$
E
$$


CONVERSION ANDIOA FUEL FABRICATION PLANTS

NUCLEAR MATERIAL ACCOUNTANCY

27. FOR EACH KEY MFASUAERENT POINT IDENTIFICD UNDER O'S 14,23 GIVE THE FOLLOWING:

See Section 27.

1) Idontification

4i) Chenied end Physiced Form of Materiel

W) Ssmpling Protedureliand Equipment Used

tw) Arssurementianslytucal Mathod und Equigument Vied

v) Source and levet of Randsin and Svetamutie Erron

(momighing, volum, sampling, enalytieni)

v) Muthos of Converting Source Dots to Esich Date

Itendard catculative proceduret, comstonn

used, empiriest rolotionshiph, ste.l 


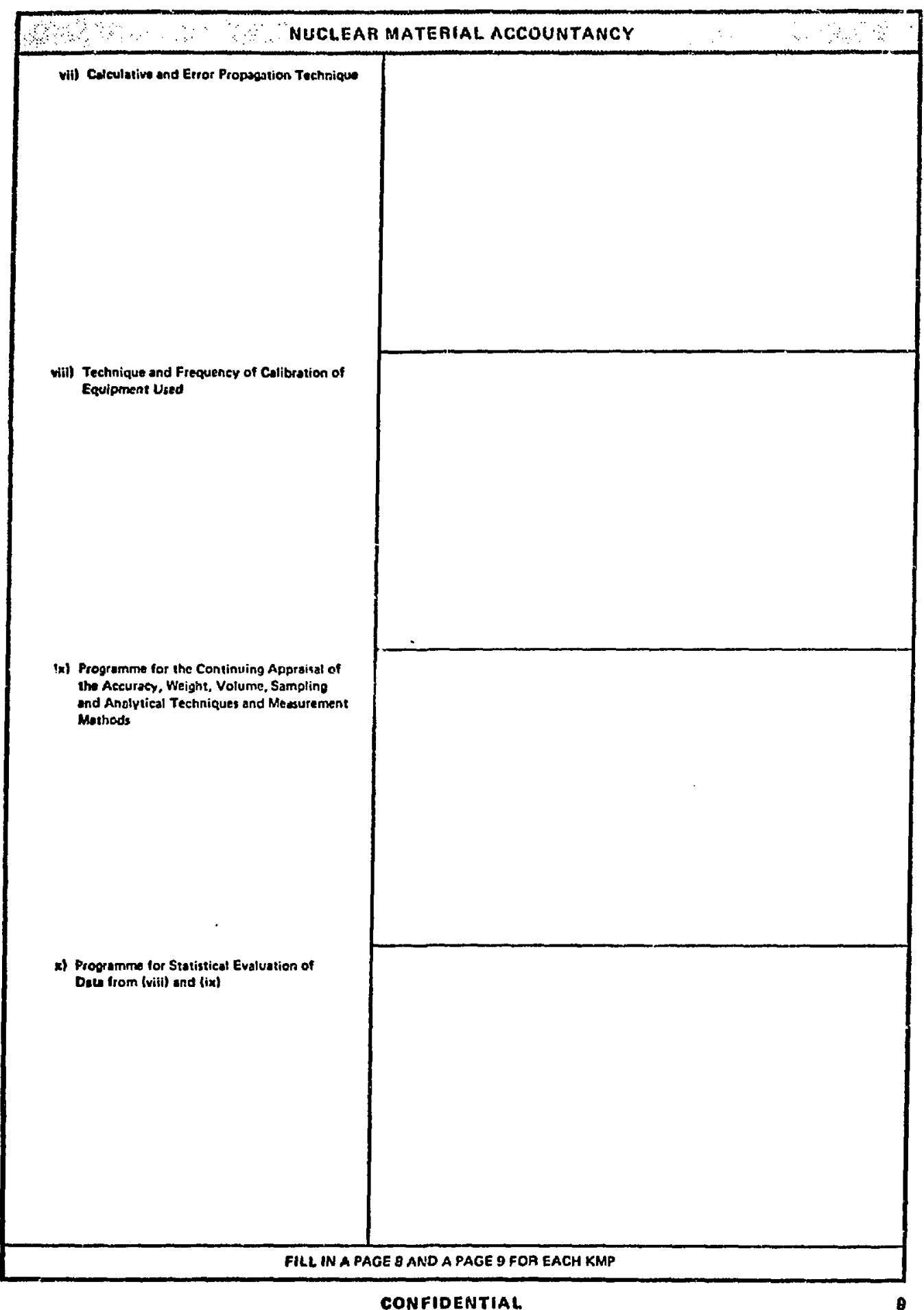


GONVERSION ANDIOR FUEL FABRICATION PLANTS

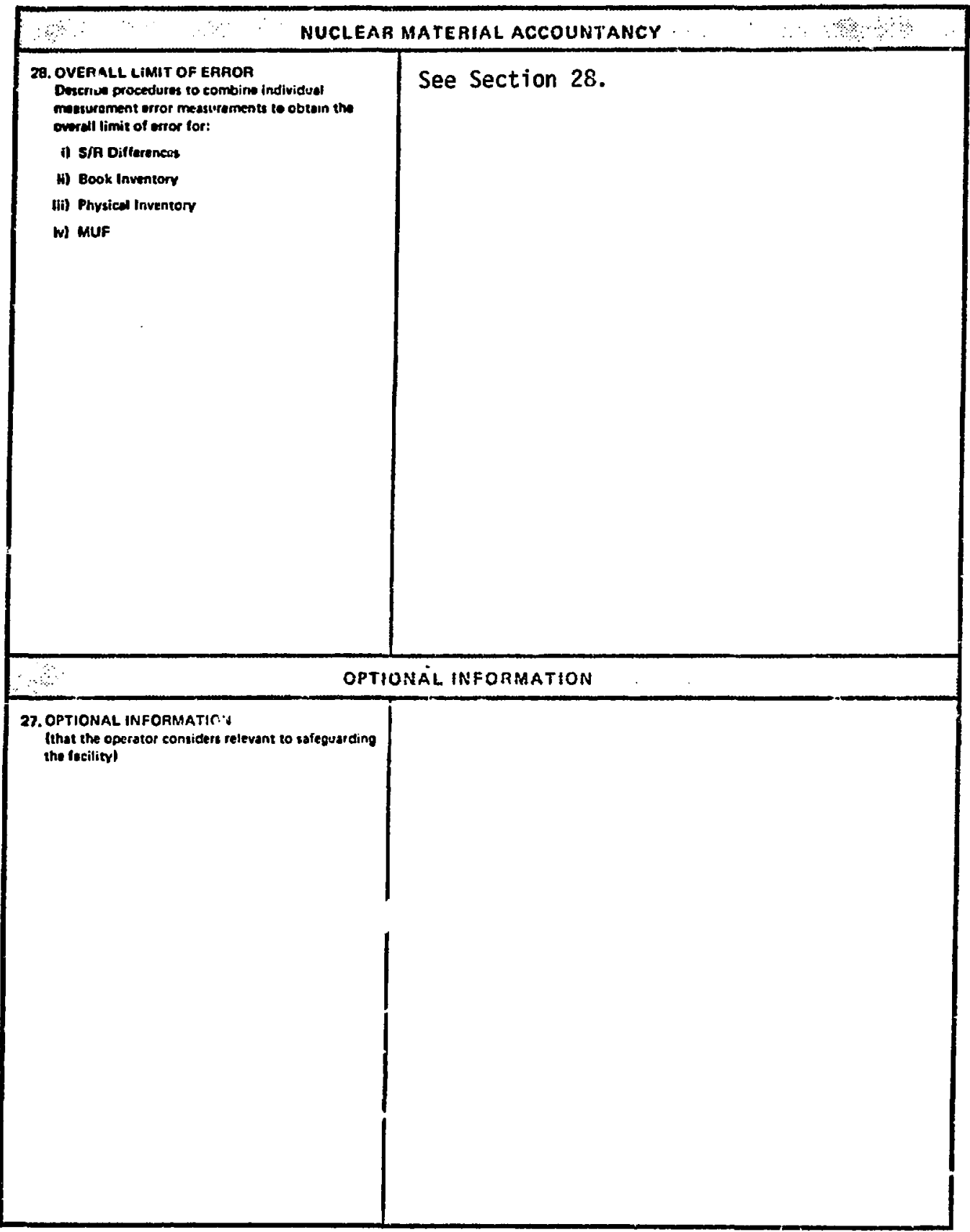

Gienature of

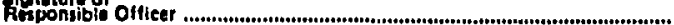

Dote 
SECTION II 
DESIGN INFORMATION QUESTIONNAIRE

(DIQ)

GENERAL INFORMATION

1. Name of Facility

A Mixed Oxide Recycle Fuels Plant (RFP)

2. Location and Postal Address

Southeast USA

3. Owner

Company $\mathrm{W}$

4. Operator

Company $W$

5. Description

A fabrication facility utilizing a mixture of uranium and plutonium oxide powders to manufacture fuel pellets and fuel rods for light water moderated nuclear power reactors.

6. Purpose

Commerical Manufacture

7. Status

Planned

8. Construction Schedule Dates

Uncertain 
9. Normal Operating Mode

Three shifts per day, seven days per week, 365 days per year minus scheduled shutdown for maintenance

10. Facility Layout

See attachment, Fig. 10-1

11. Site Layout

See attachment, Fig. 11-1

12. Names and/or Titles of Responsible Officers

Nuclear Materials Manager Reporting to Plant Manager

OVERALL PROCESS PARAMETERS

13. Eacility Description

See attachments 13-1 through 13-6

14. Process Description

The overall process is described by the block diagrams on attachments, Fig. 14-1 and 14-2. Each of the individual process steps identifid on Fig. 14-1 is further described in attachments, Figs. 14-3 through 14-10. The process is divided into six MBA's and five ICA's (item control areas) as shown on Figs. 14-1 and 14-2. MBA-2, the mixed oxide pellet processing area, is composed of seven subMBA's. Material is controlled within each sub-MBA and transfers between sub-MBA's are recorded. Material transfered between sub-MBA's is measured, but generally only before transfer or after receipt, not both. The physical boundaries of these MBA's and ICA's are shown in attachments, Figs 14-11 and 14-12. The key measurement points (KMP) are identified in Figs. 14-13 and 14-14 and are described 


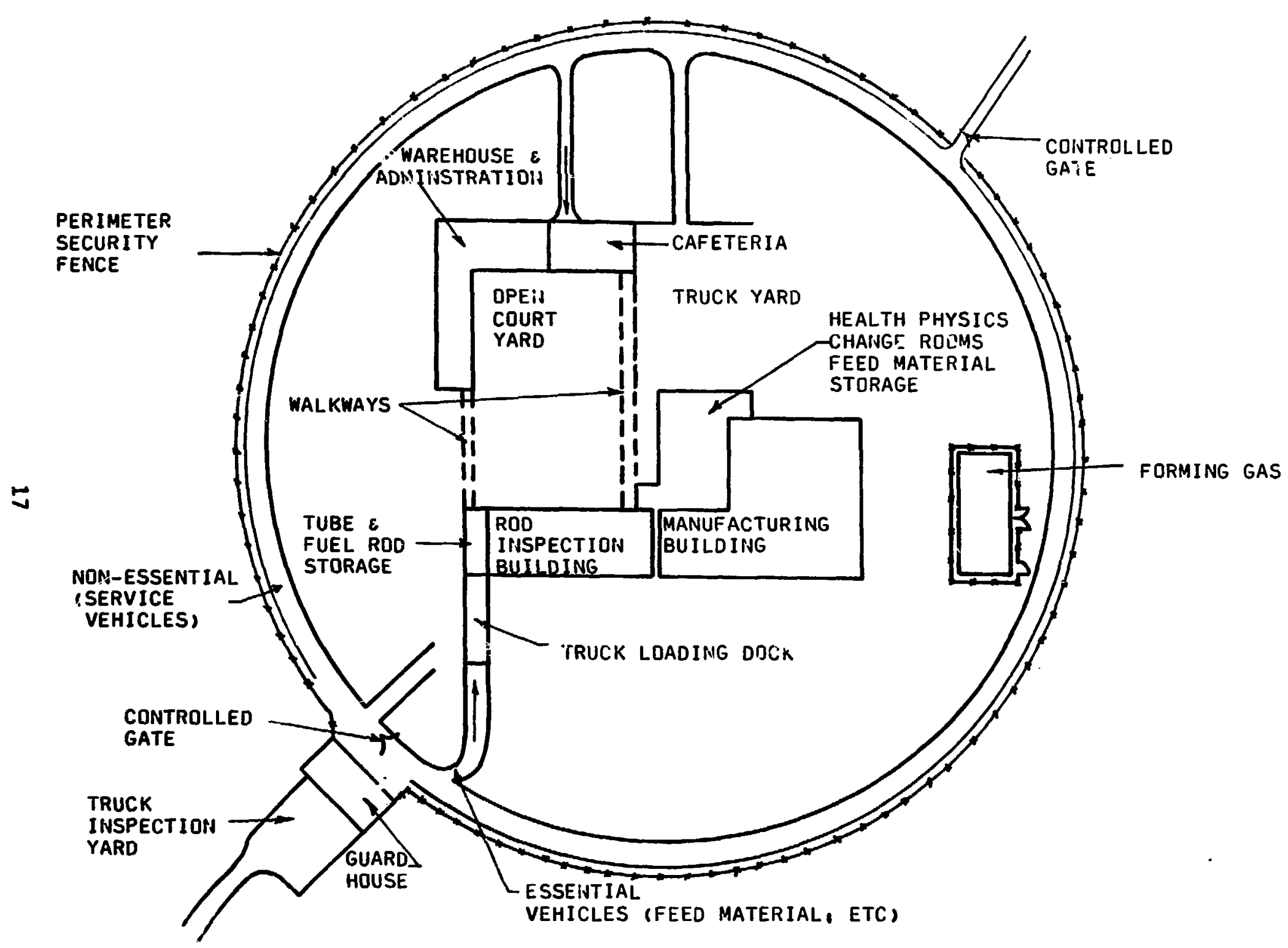

Figure 10-1. Faciiity Layout Recycle Fuel Plant (RFP) 


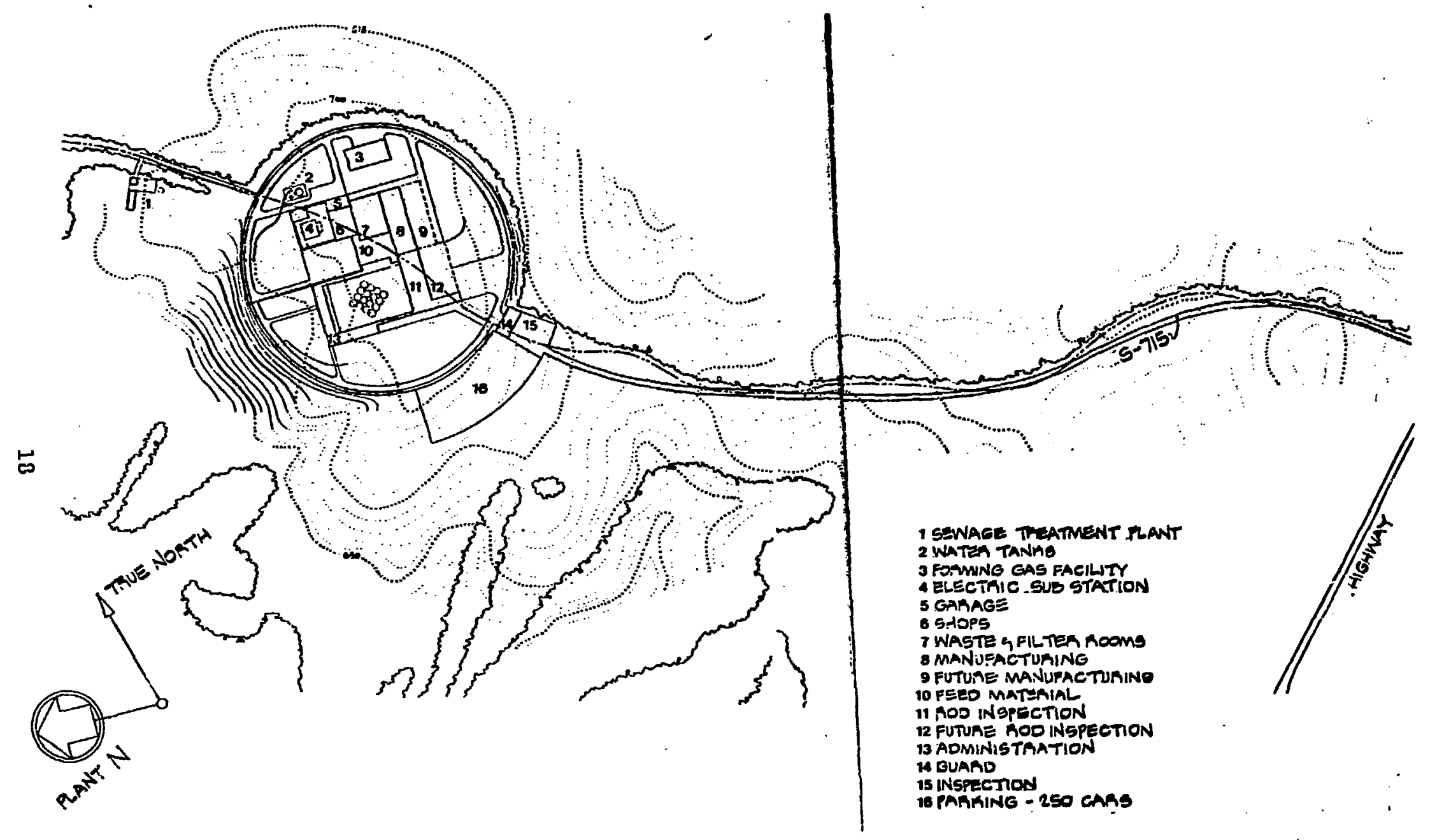

Figure 11-1. Site Plan for Recycle Fuel Plant (RFP) 


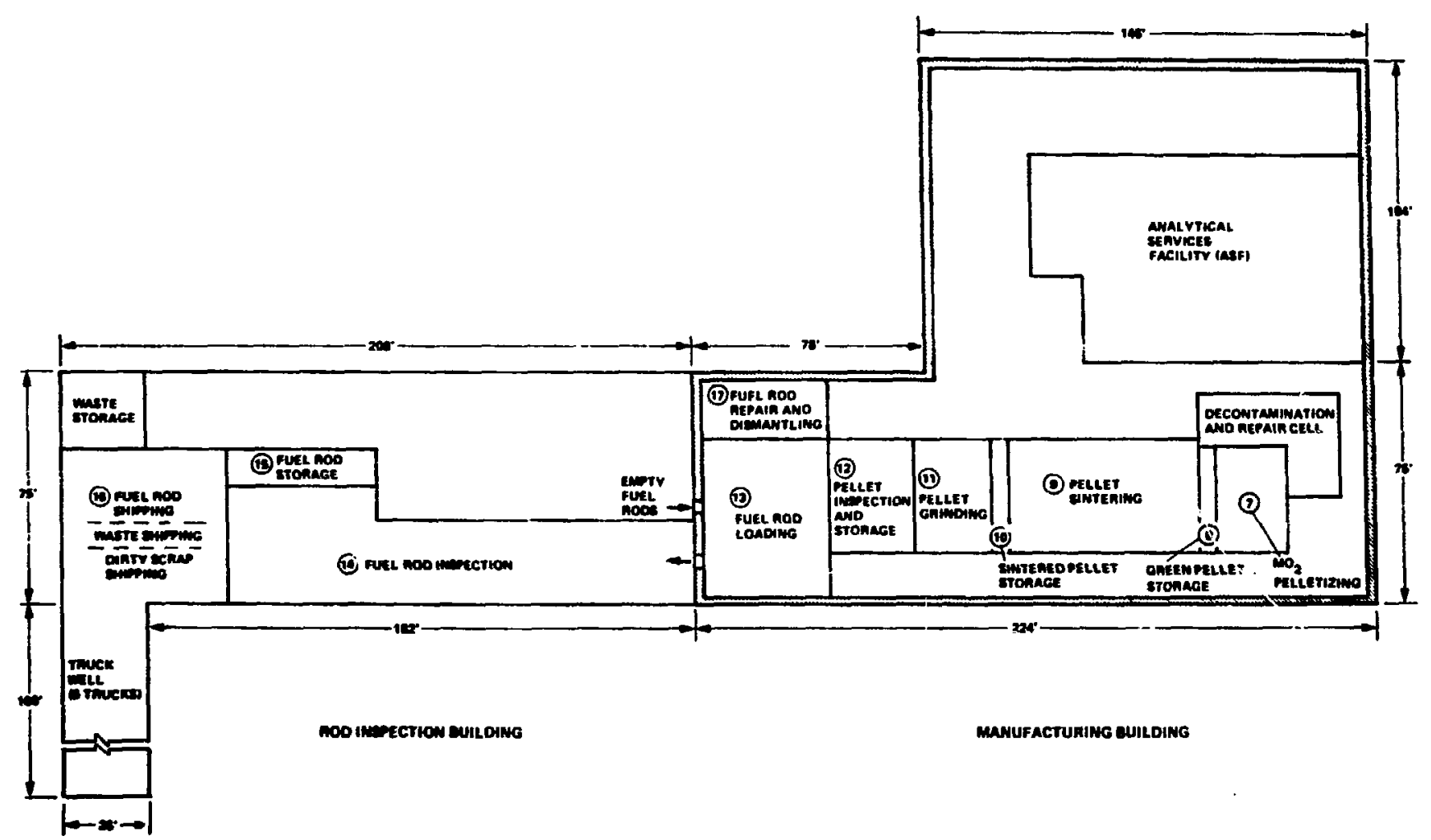

Figure 13.1. First Floor Level of $\mathrm{MO}_{2}$ Fuel Plant 


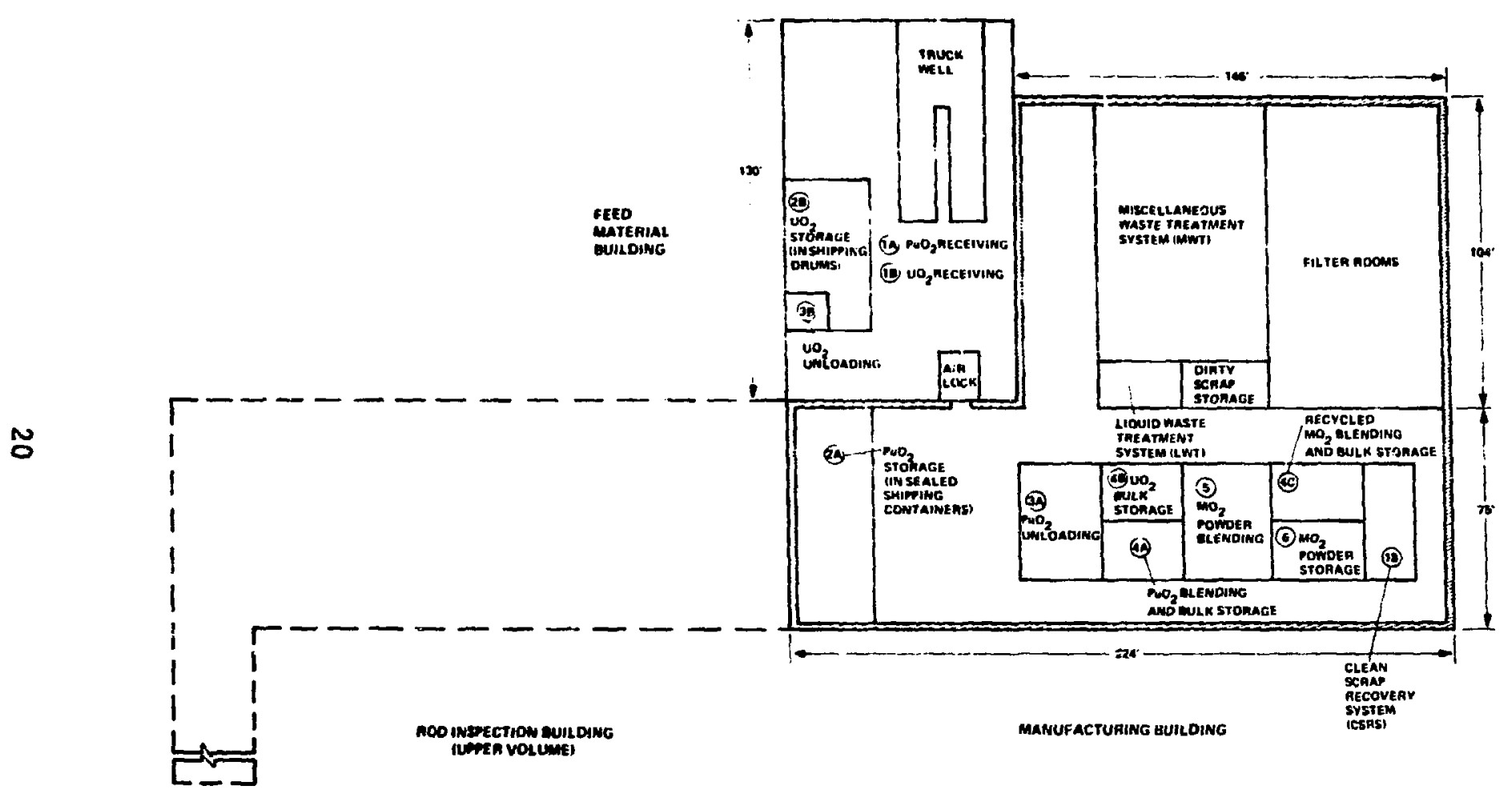

Figure 13.2. Second Floor Level of $\mathrm{MO}_{2}$ Fuel Plant 


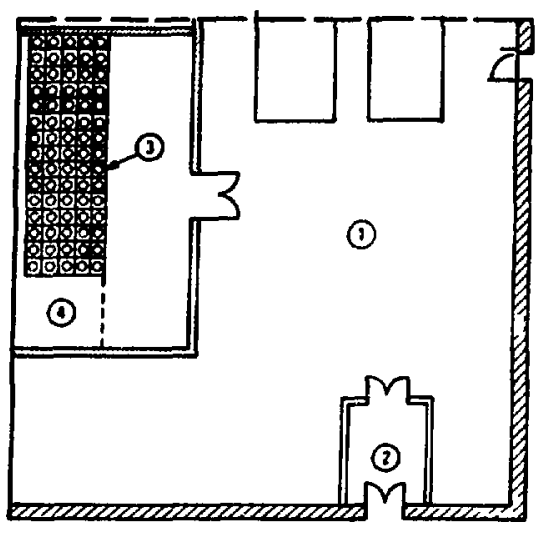

1. RECEIVING DOCK

2. EQUIPMENT AIR LOCK

3. $\mathrm{UO}_{2}$ STORAGE IN DRUMS

4. $\mathrm{UO}_{2}$ UNLOADING AREA

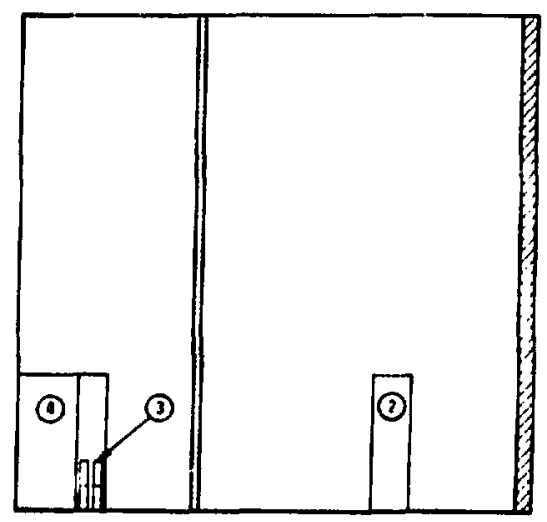

Figure 13.3. Top and Side Views of Feed Material Building for $\mathrm{MO}_{2}$ Fuel Plant 


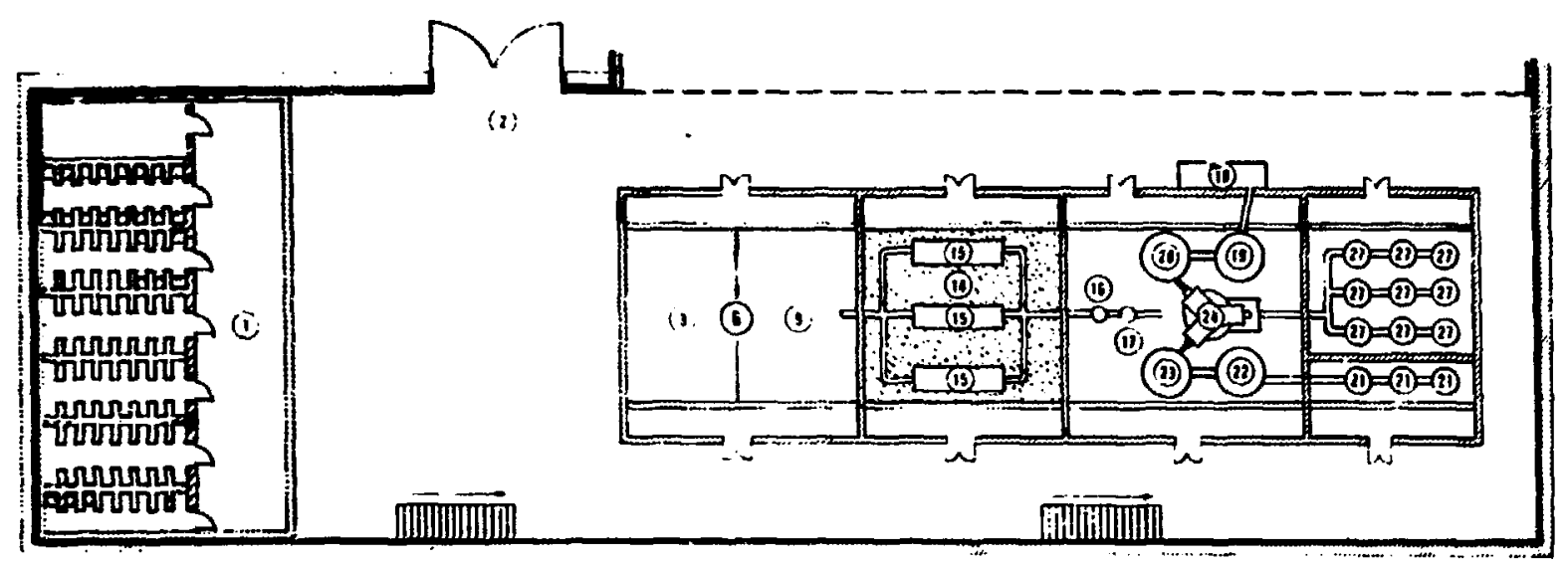

N

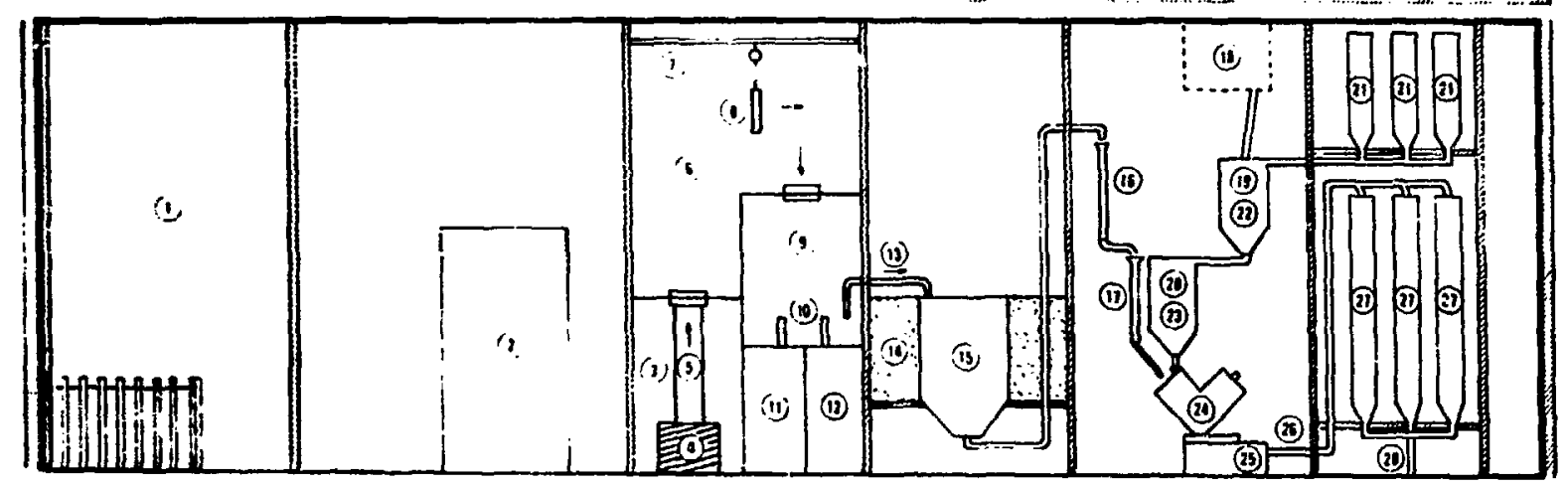

1. Mo, L.10 stonage

2. EOUIHEENT AIA LOCK

3. L.10 OFEHING COMARTMENT

4. DLLLY \& SCREWIACK

5. L 10 in UNLLADING POSITION

c. TRAMSFER COMMARTMENT

7. monorasll
8. SEALEO OUTER CAN

9. CONTAIHER OPENING COMPARTMENT

10. SEALED INMER CAN

11. SCRAP \& RECOVEAY

12. CAN COMPACTING

13. PNEUMATIC FOMDER TRANSFER

14. SHIELDING E POISON
15. PuO ${ }_{2}$ STORAGE

16. PUO 2 FEED HOPPER

17. PuO 2 HEIGH HOPPER

18. UO, STORAGE

19. $V O_{2}$ FEED HOPPER

20. $\mathrm{VO}_{2}$ WEIGH HOPPER

21. RECYCLED $\mathrm{MO}_{2}$ STORAGE
22. $\mathrm{MO}_{2}$ FEED HOPPER

23. $\mathrm{MO}_{2}$ WEIGH HOPPER

24. BLENDER

25. AEDUCTION MILL

26. TO $\mathrm{MO}_{2}$ STOAAGE

27. $\mathrm{MO}_{2}$ STORAGE SILO

28. TO SLUG PRESS HOPPER

Figure 13.4. Top and Side Views of 2nd Floor Manufacturing Building for $\mathrm{MO}_{2}$ Fuel Plant 

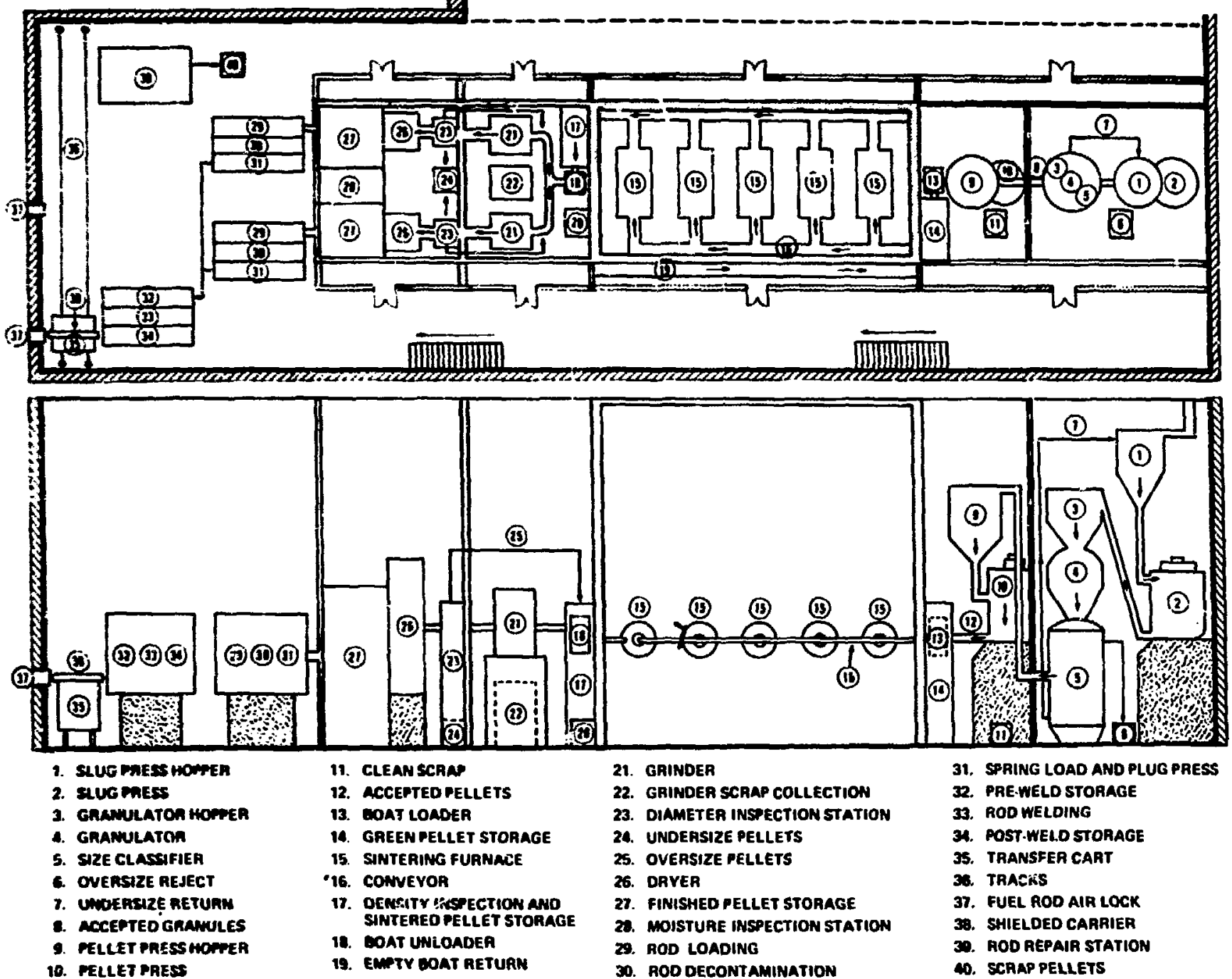

11. CLEAN SCAN"

12. ACCEPTED PELLETS

13. DOAT LOADER

21. GAINDER

14. Gaeen pellet storage

15. SINTERING FURNACE

16. Conveyon

DEMSITY LASPECTION ANO SINTEREO PELLET STORAGE

18. DoAT uniondef

19. EMTY EOAT RETURM

20. AEJECTED PELLETS
22. GRINDER SCRAP COLLECTION

23. DIAMETER INSPECTION STATION

24. UNDERSIZE PELLETS

25. OVERSIZE PELLETS

26. DRYER

27. FINISHED PELLET STORAGE

22. MOISTUAE INSPECTION STATION

29. ROD LOADING

30. ROD DECONTAMINATION
31. SPRING LOAD AND PLUG PRESS

32. PAE-weld Storage

33. ROD WELOING

34. POST.WELL STORAGE

35. TRANSFER CART

33. TRACKS

37. FUEL AOD AIR LOCK

38. SHIELDED CARRIER

30. MOD REPAIR STATION

40. SCAAP PELLETS

Figure 13.5. Top and Side Views of 1st Floor Manufacturing Building for $\mathrm{MO}_{2}$ Fuel Plant 

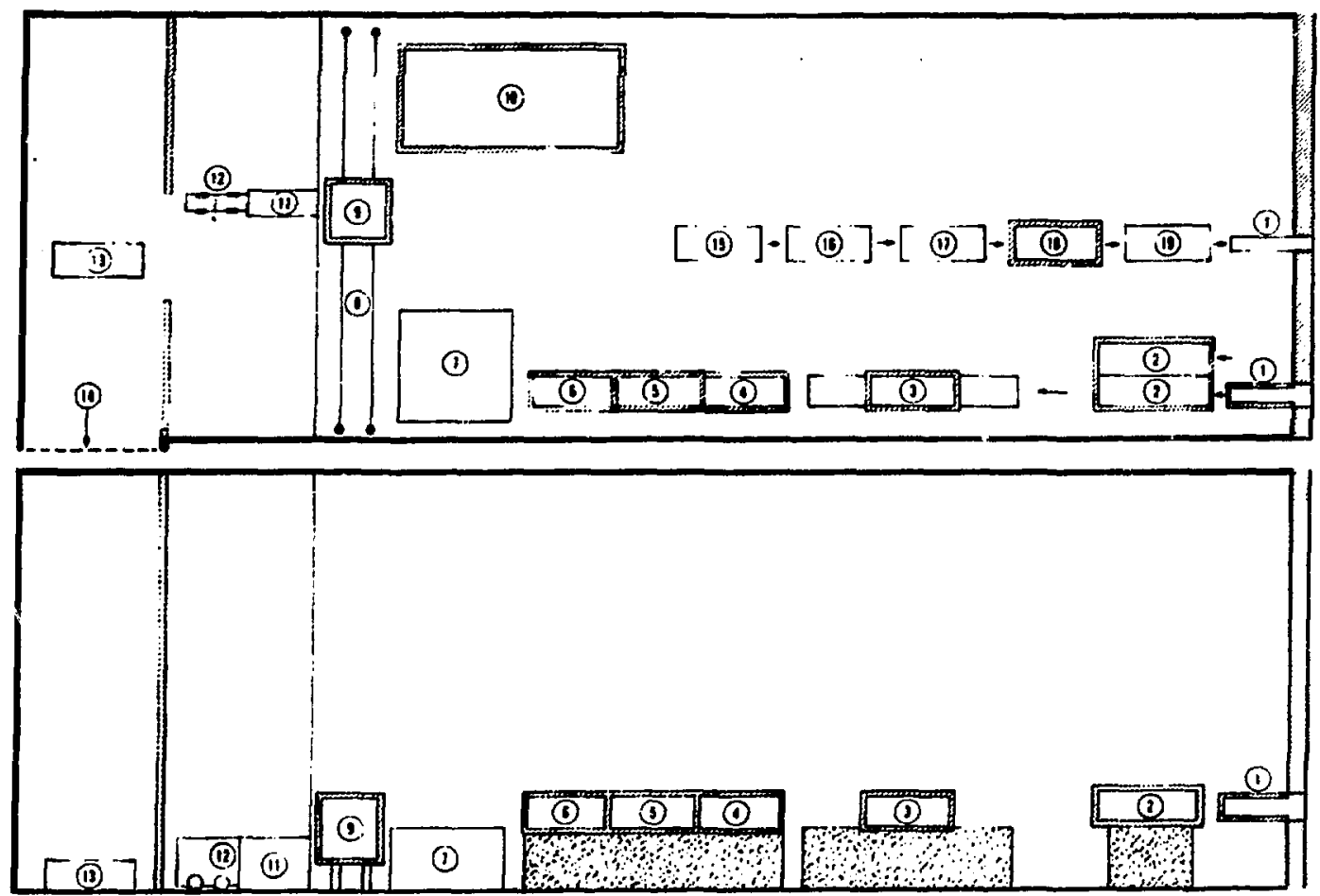

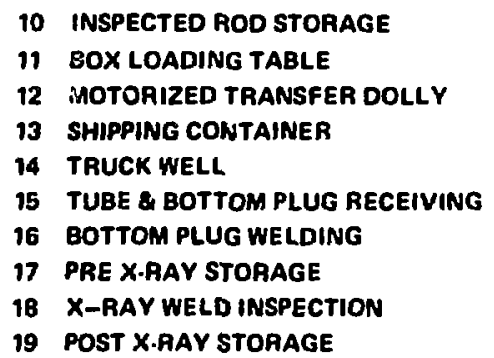

FIgure 13.6. Top and Side Views of 1st Floor Fuel Rod Inspection Building for $\mathrm{MO}_{2}$ Fuel Plant 


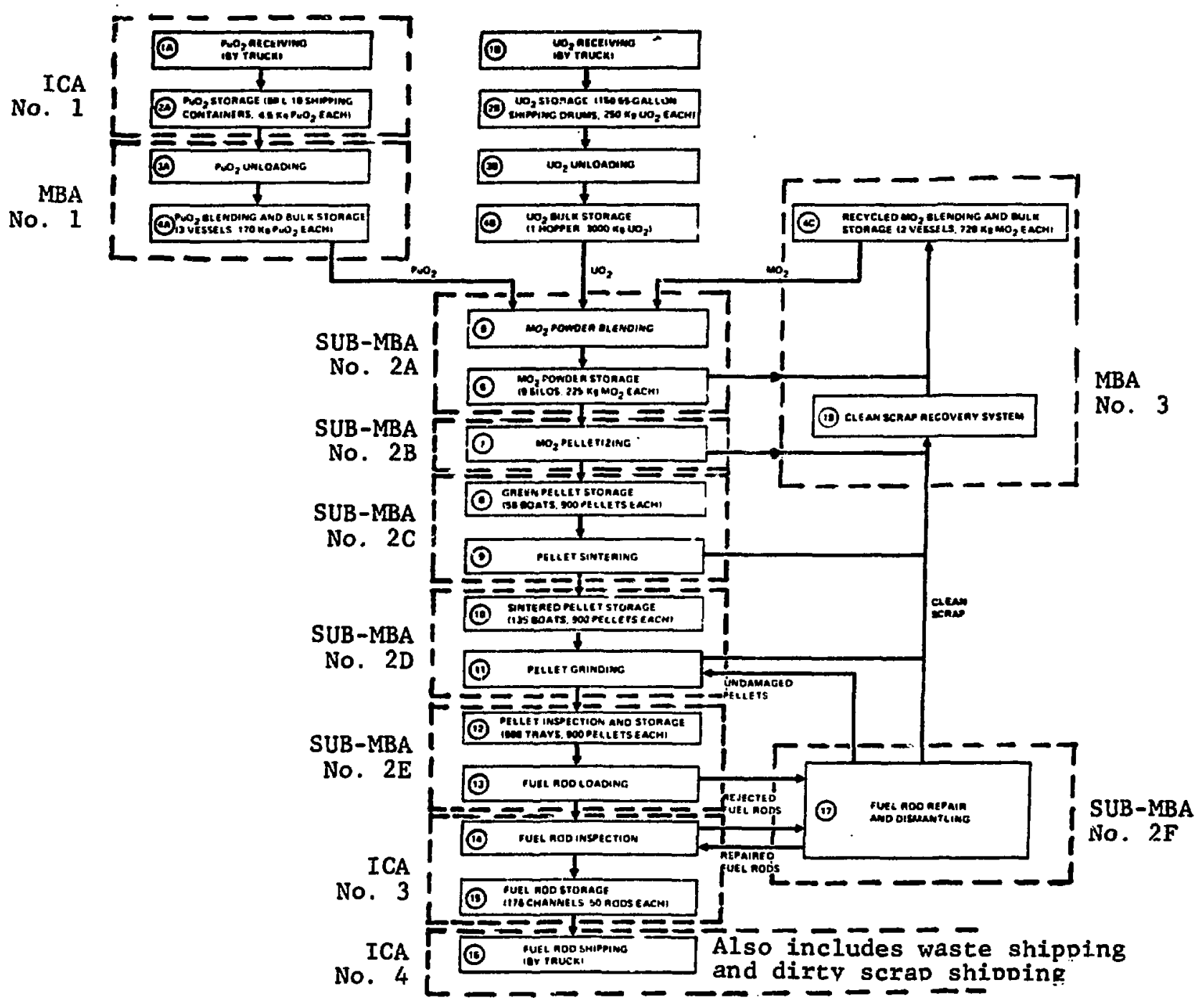

Figure 14.1. Feed, Product and Clean Scrap Flow for $\mathrm{MO}_{2}$ Fuel Plant 


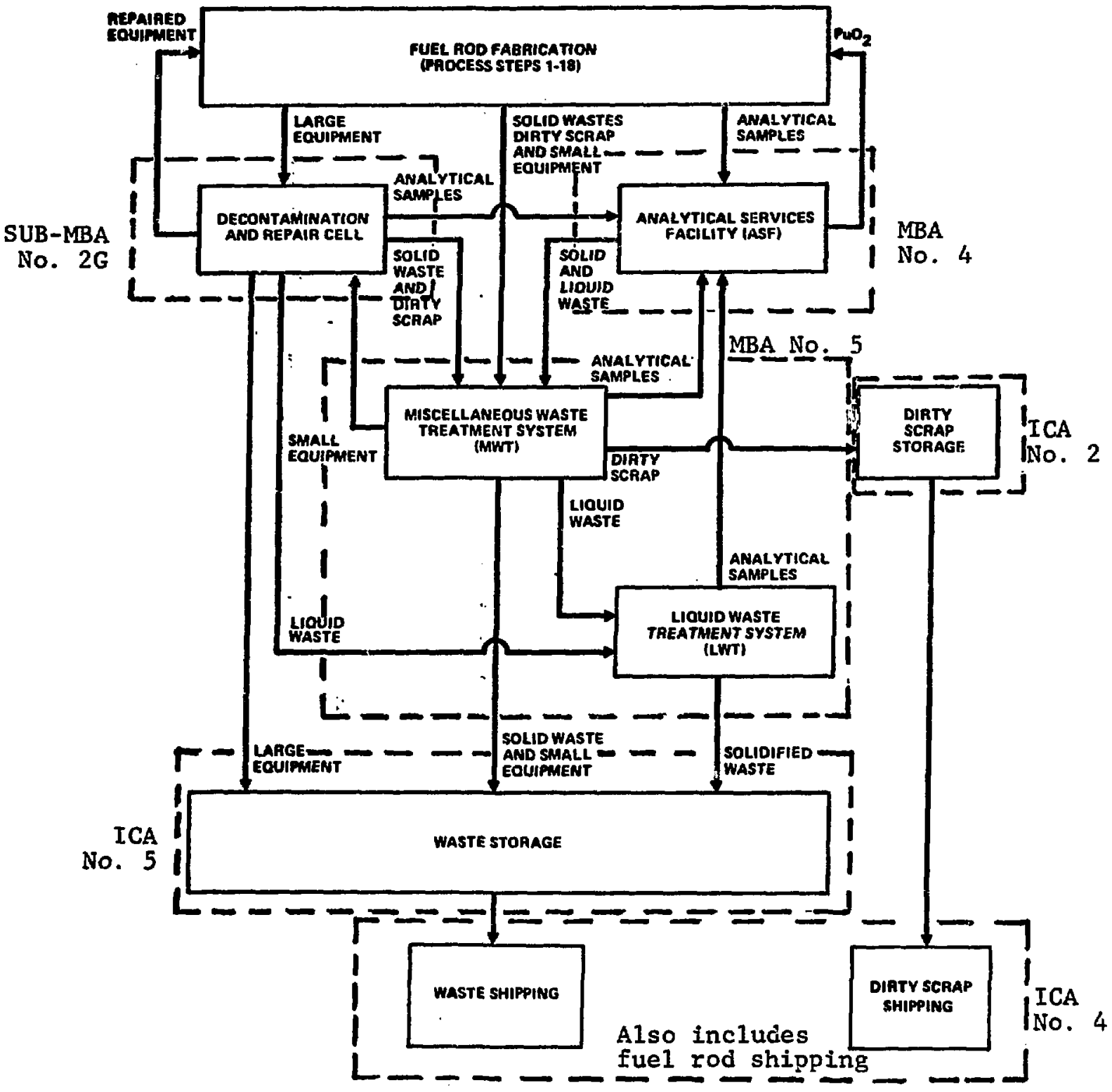

Figure 14.2. Waste and Dirty Scrap Flow for $\mathrm{MO}_{2}$ Fuel Plant 


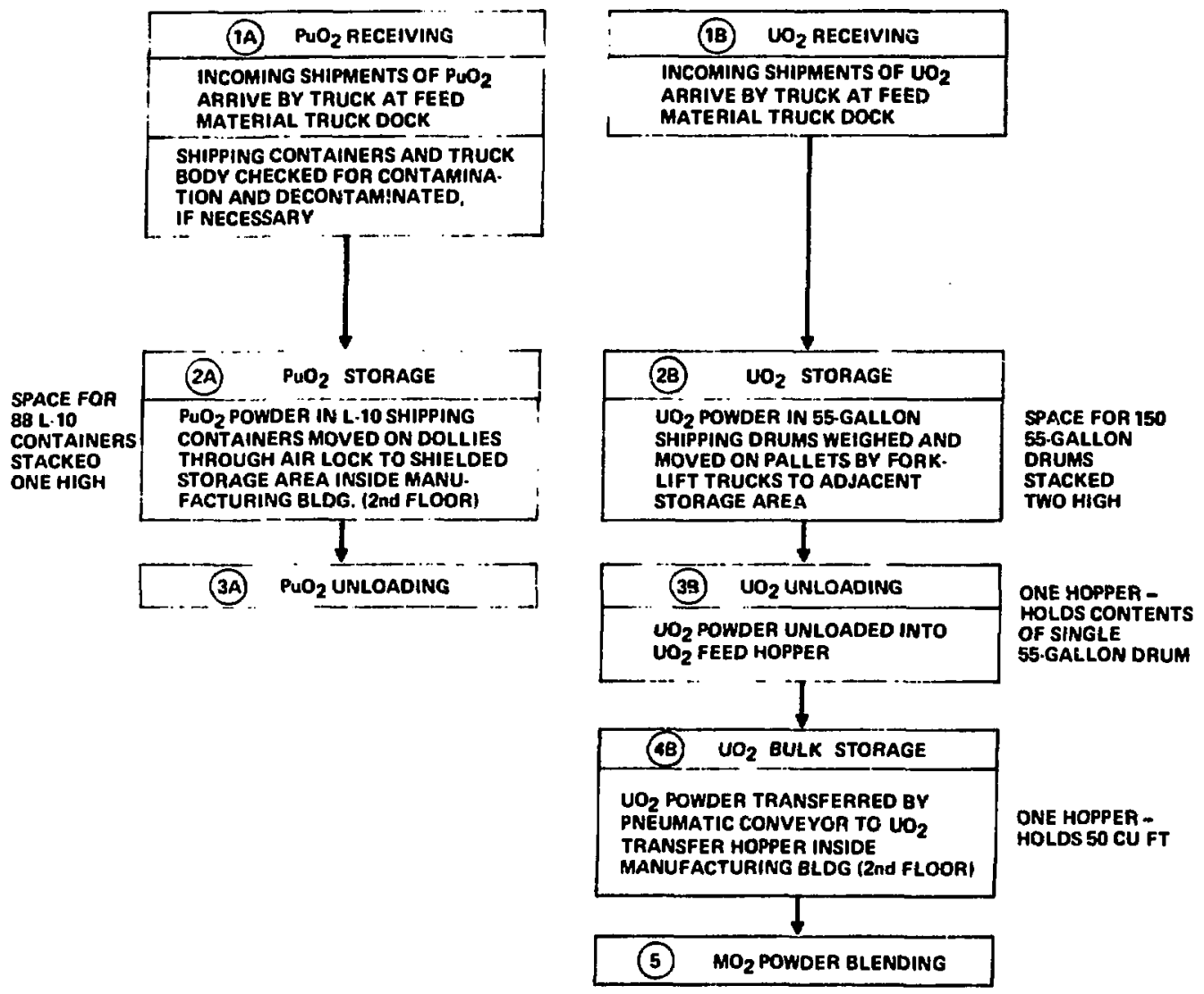

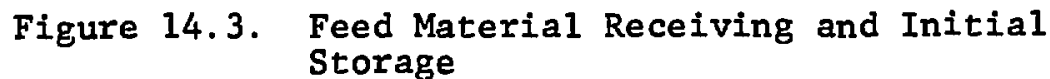




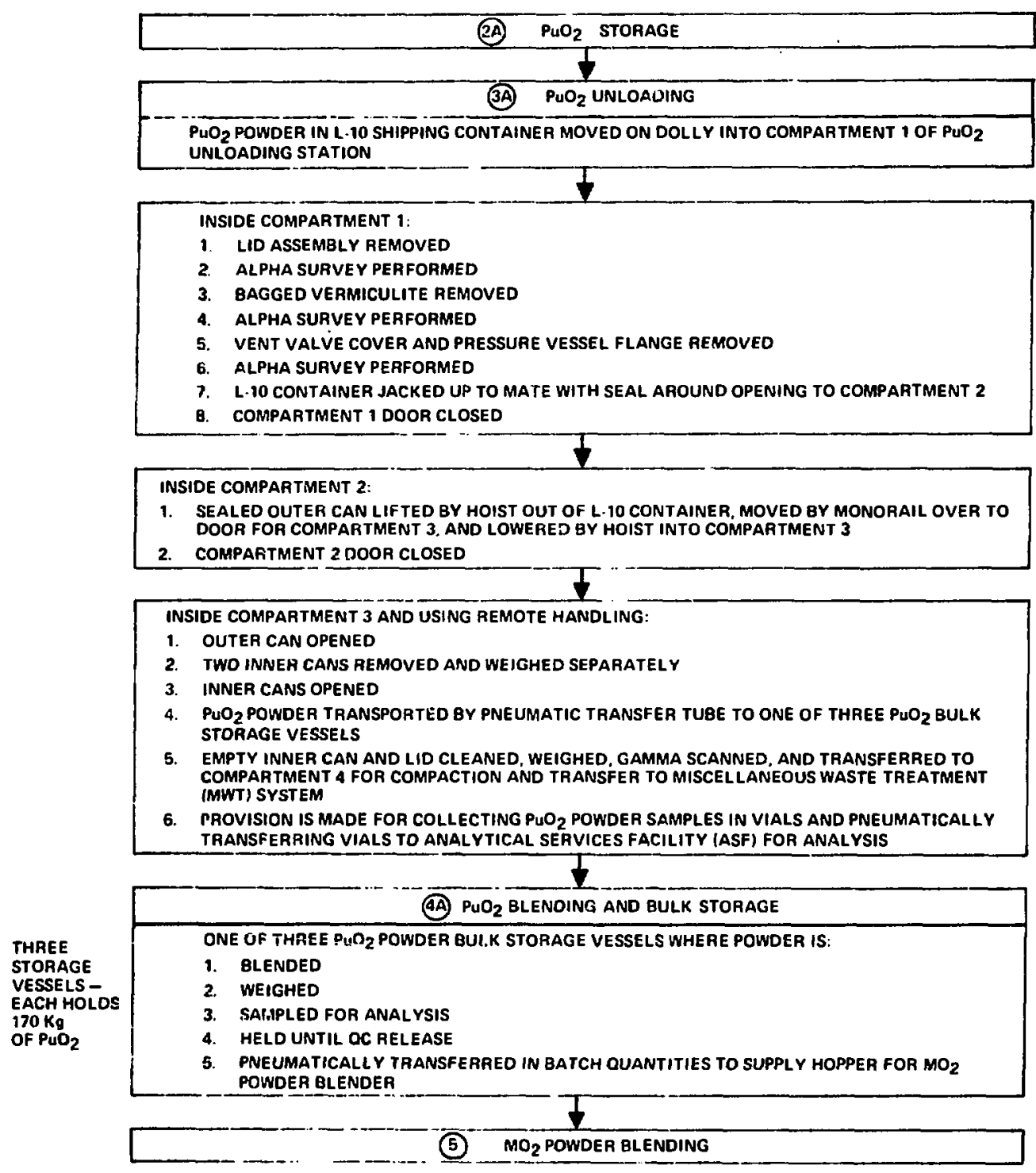

Figure 14.4. $\mathrm{PuO}_{2}$ Unloading from L-10 Containers 


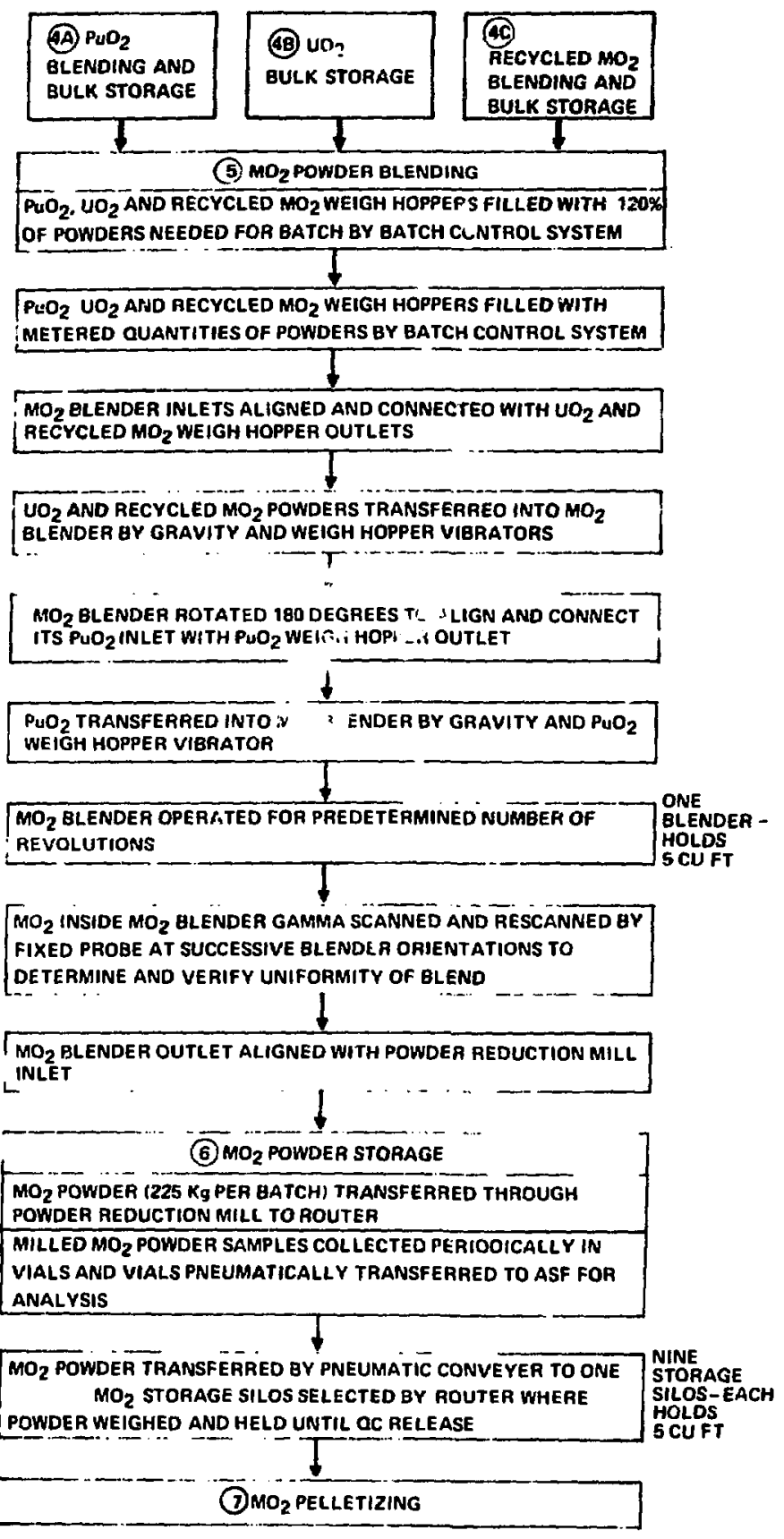

\section{Figure 14.5. $\mathrm{MO}_{2}$ Powder Blending}




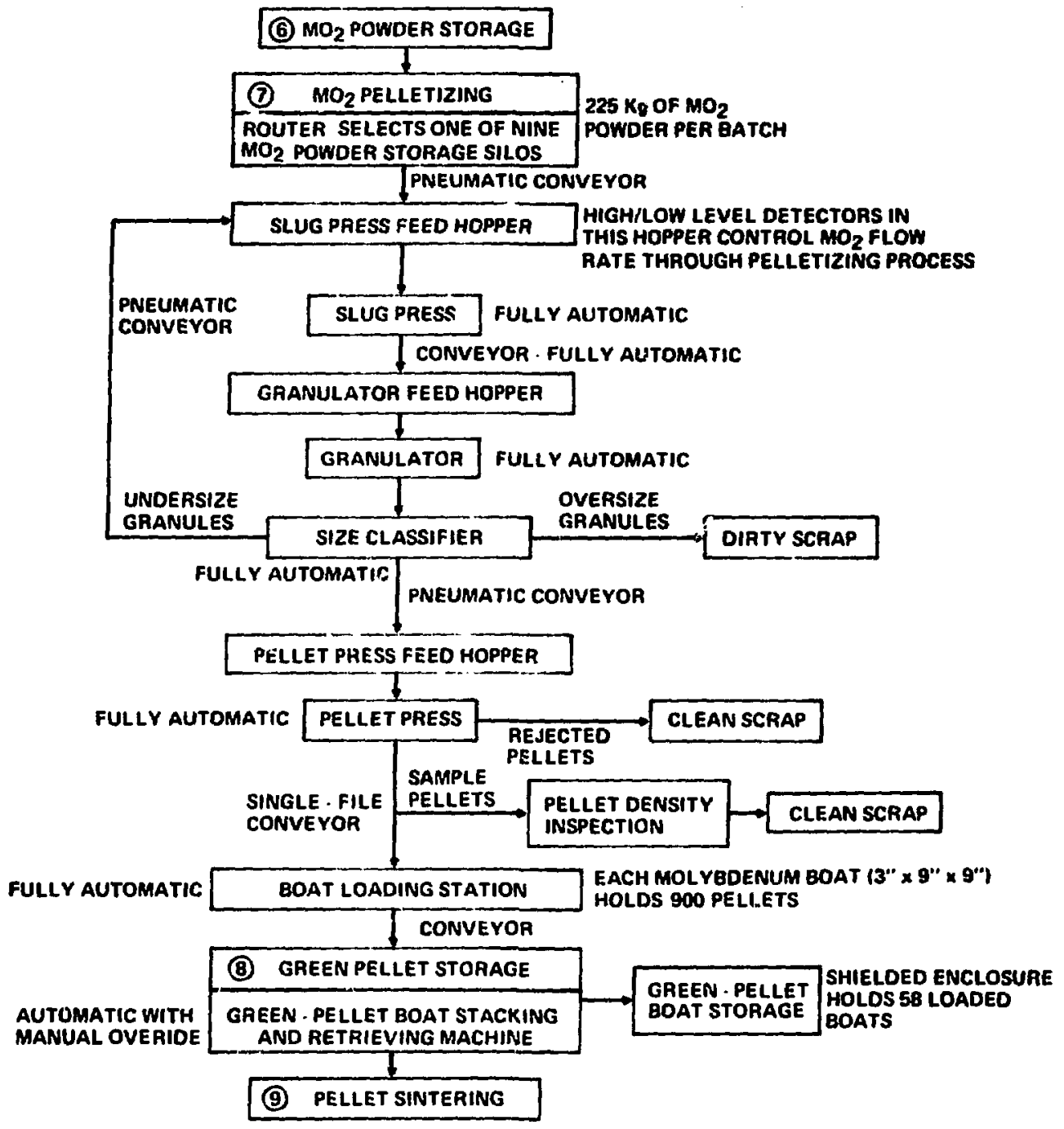

Figure 14.6. $\mathrm{MO}_{2}$ Pelletizing 


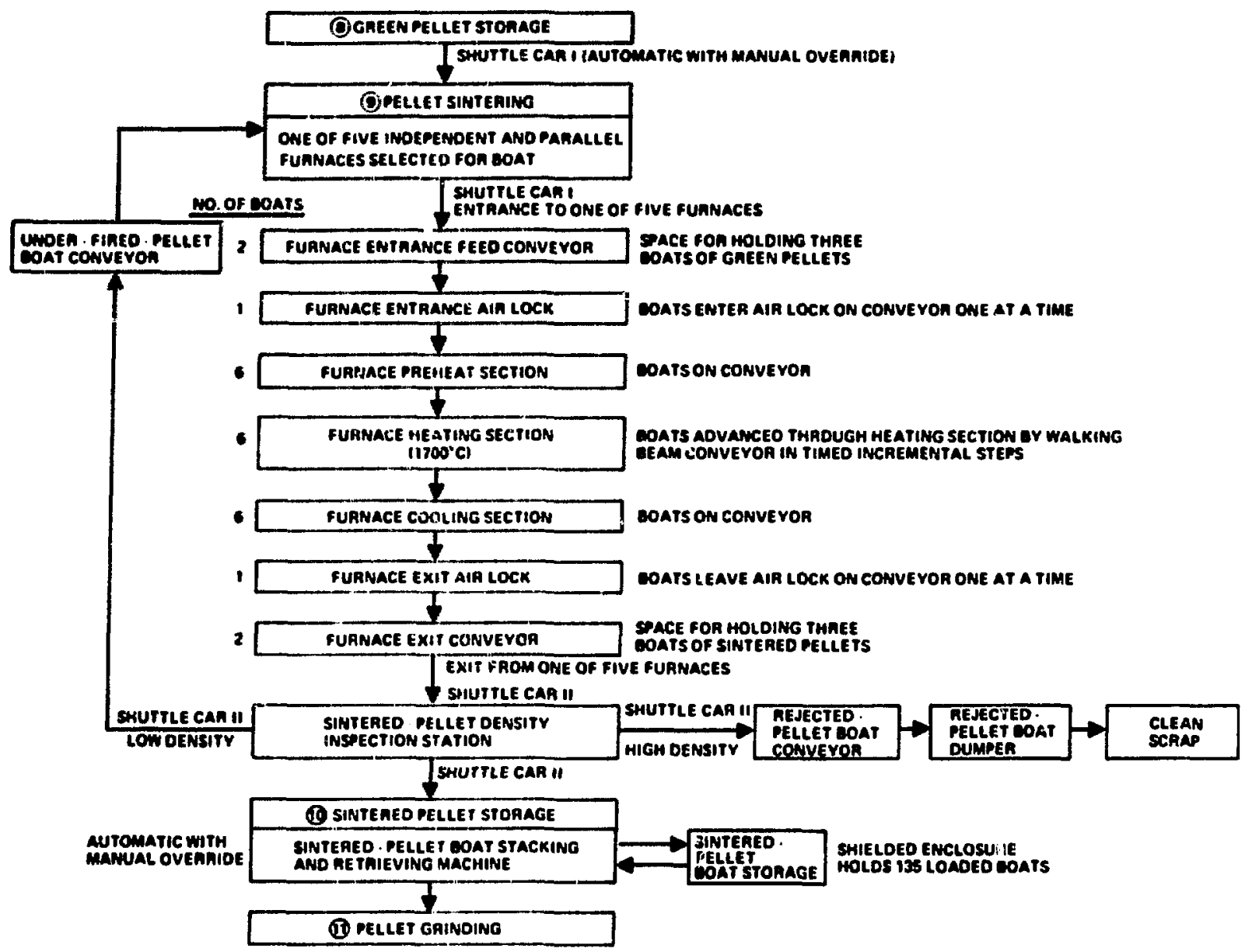

Figure 14.7. Pellet Sintering 


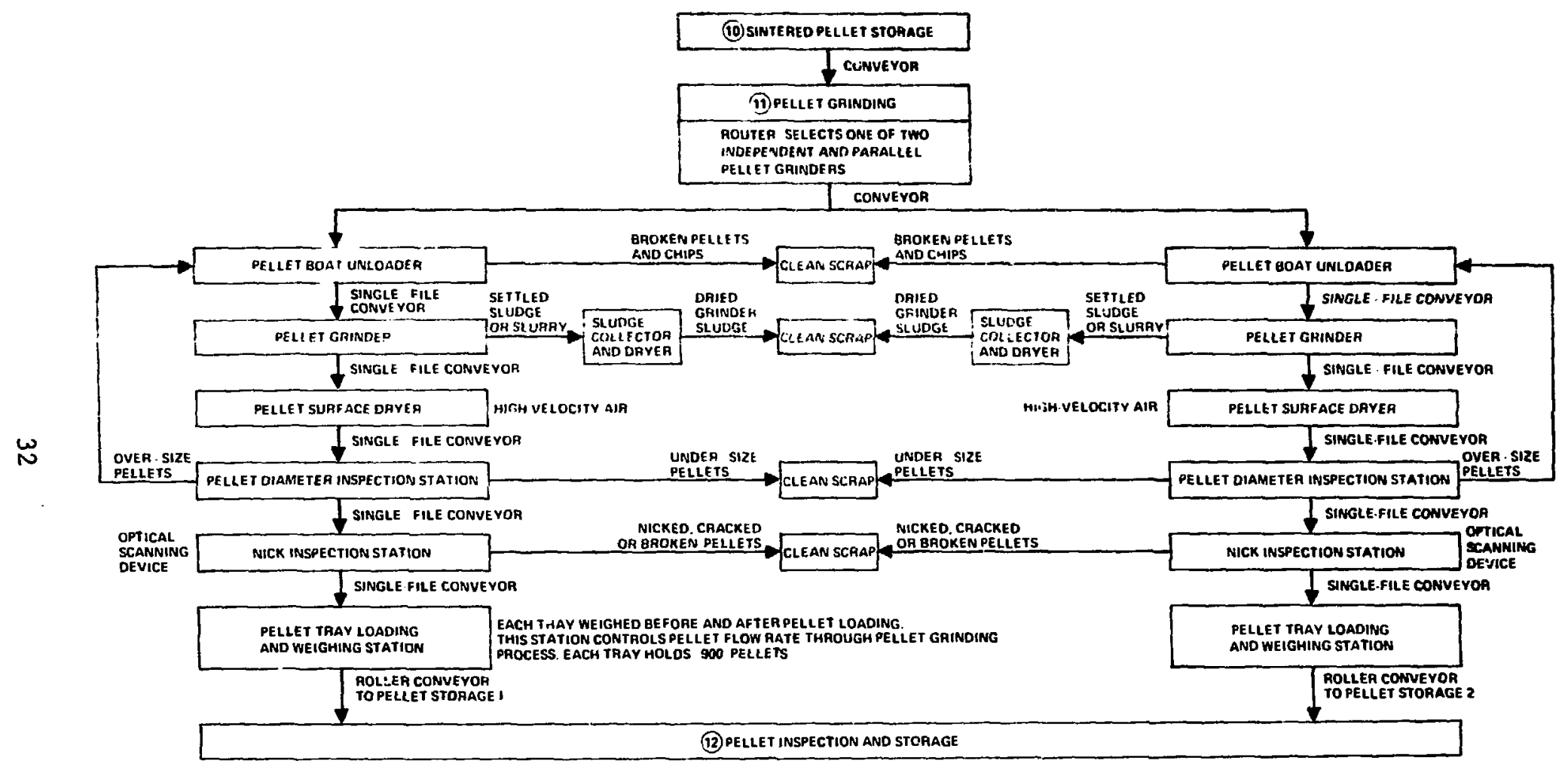

Figure 14.8. Pellet Grinding 


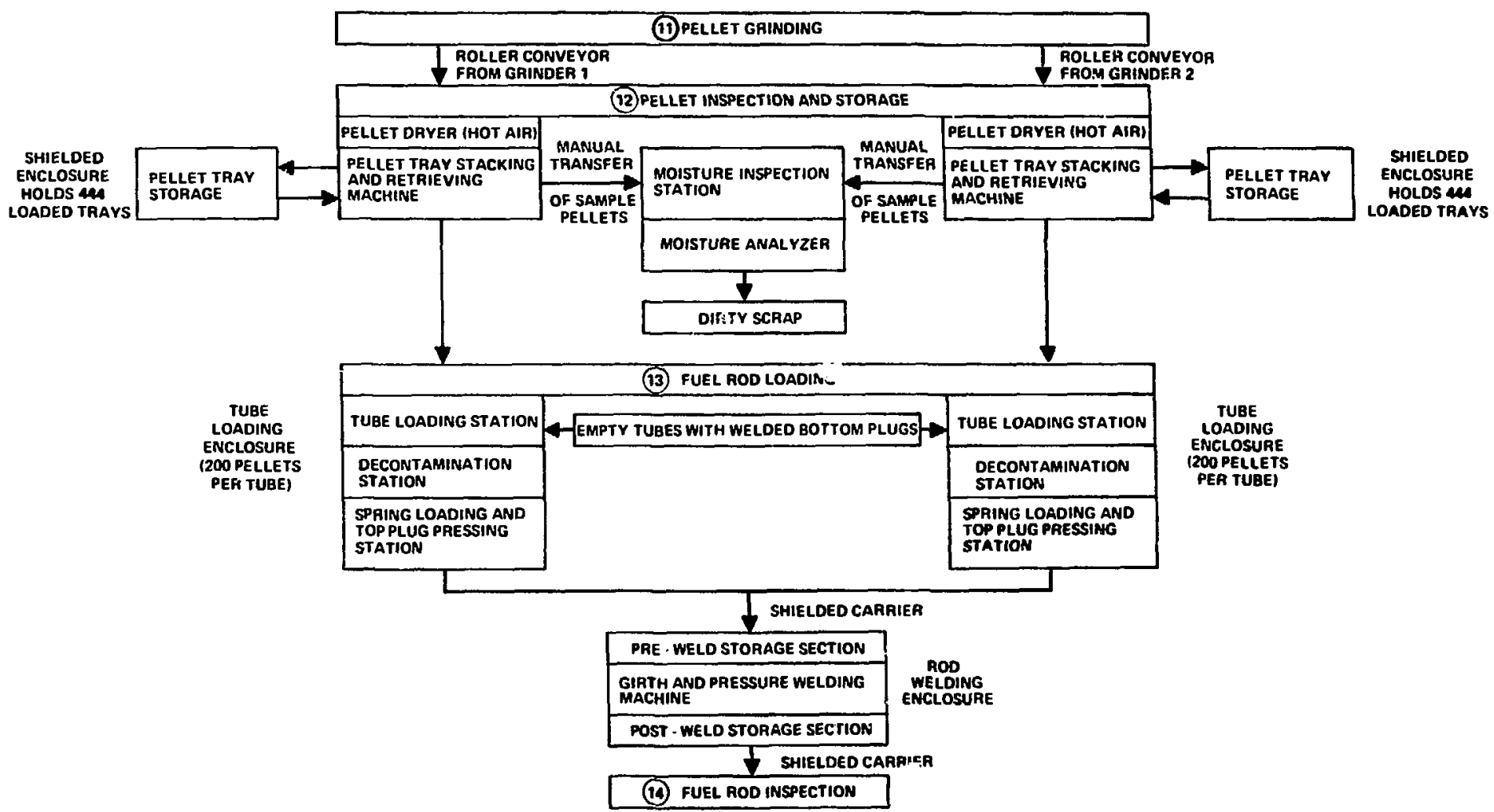

Figure 14.9. Pellet Inspection and Fuel Rod Loading 


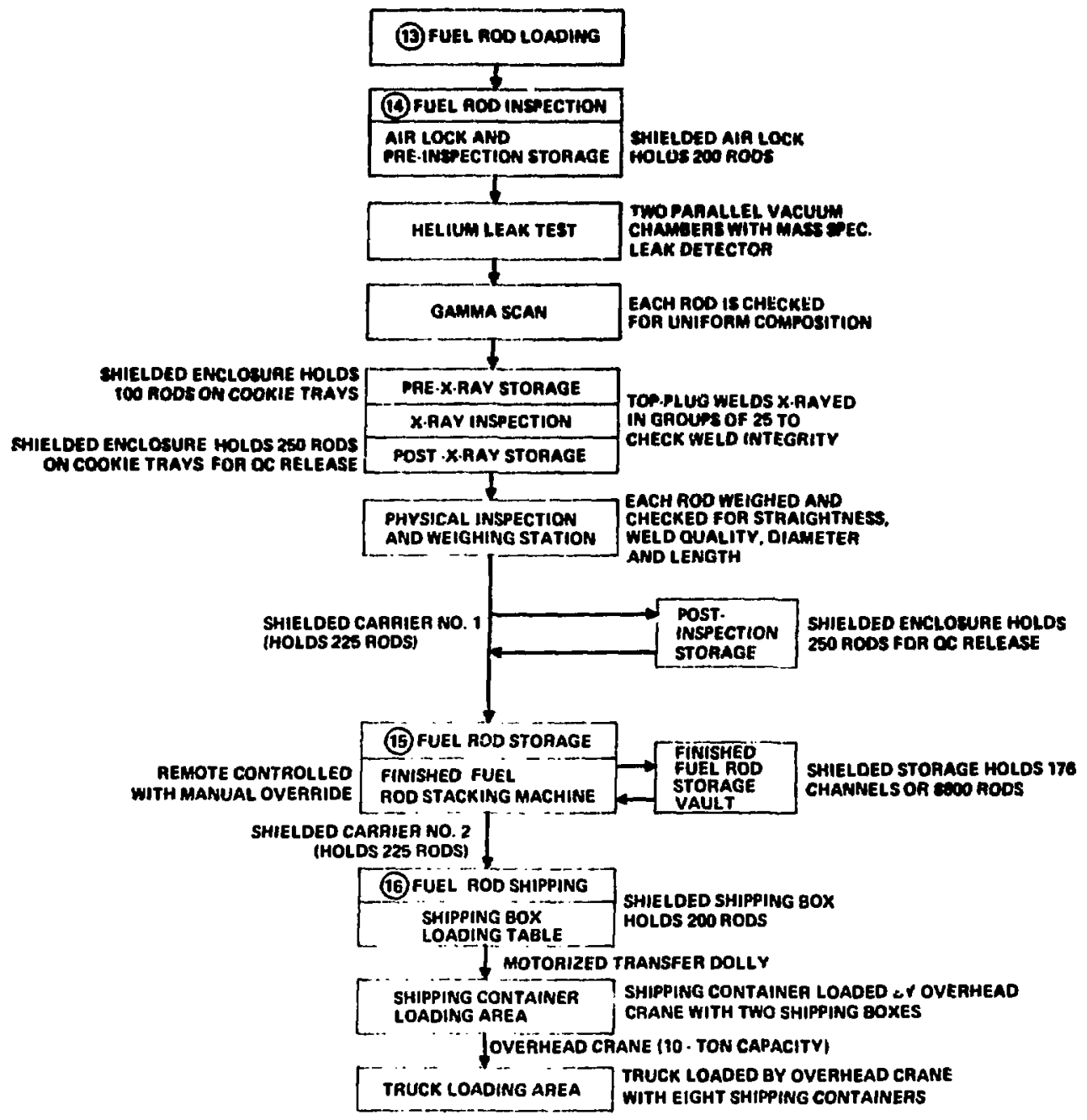

Figure 14.10. Fuel Rod Inspection, Storage and Shipping 


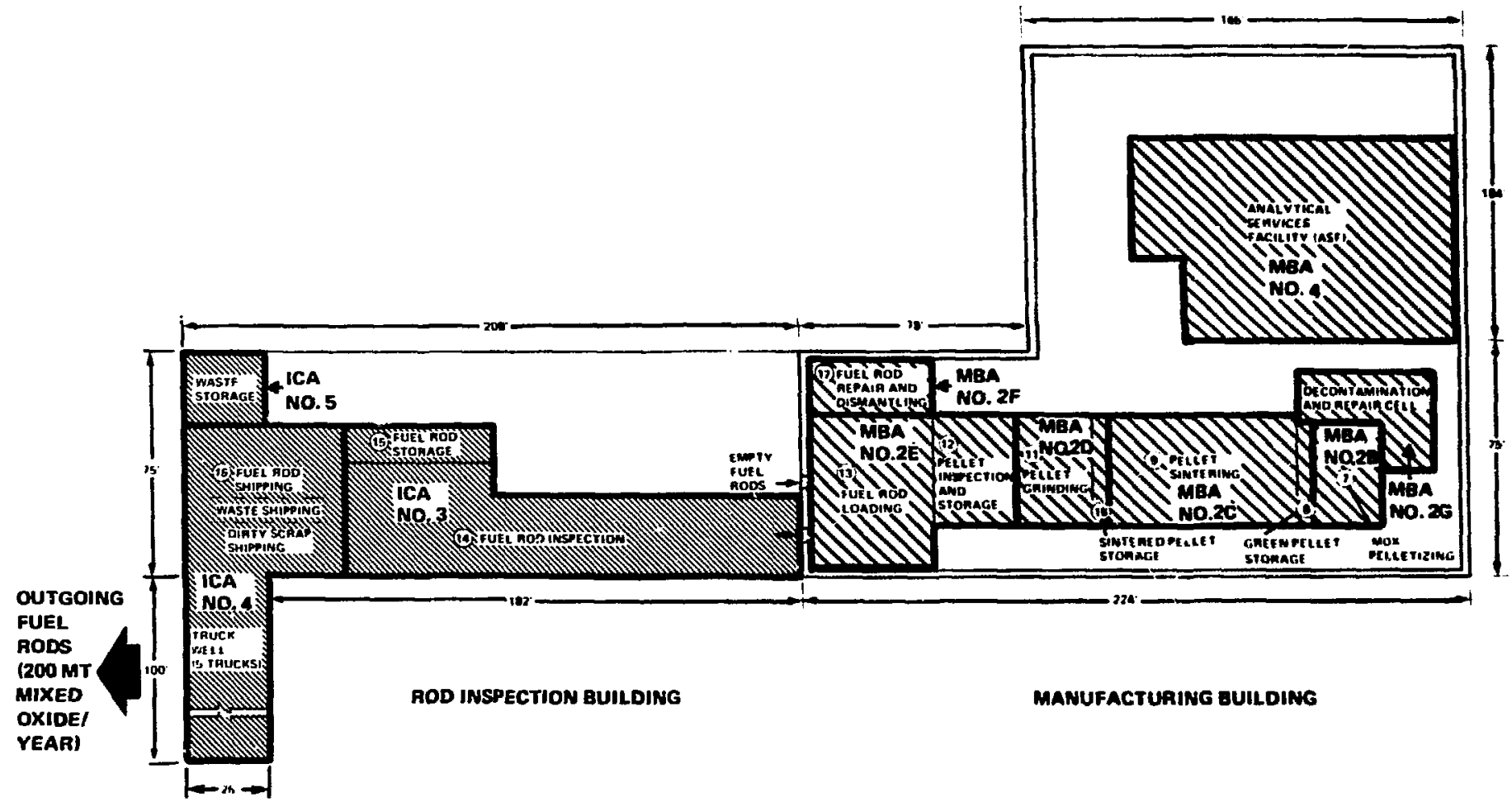

Figure 14.11. MBA and ICA for First Floor Level of $\mathrm{MO}_{2}$ Fuel Plant 


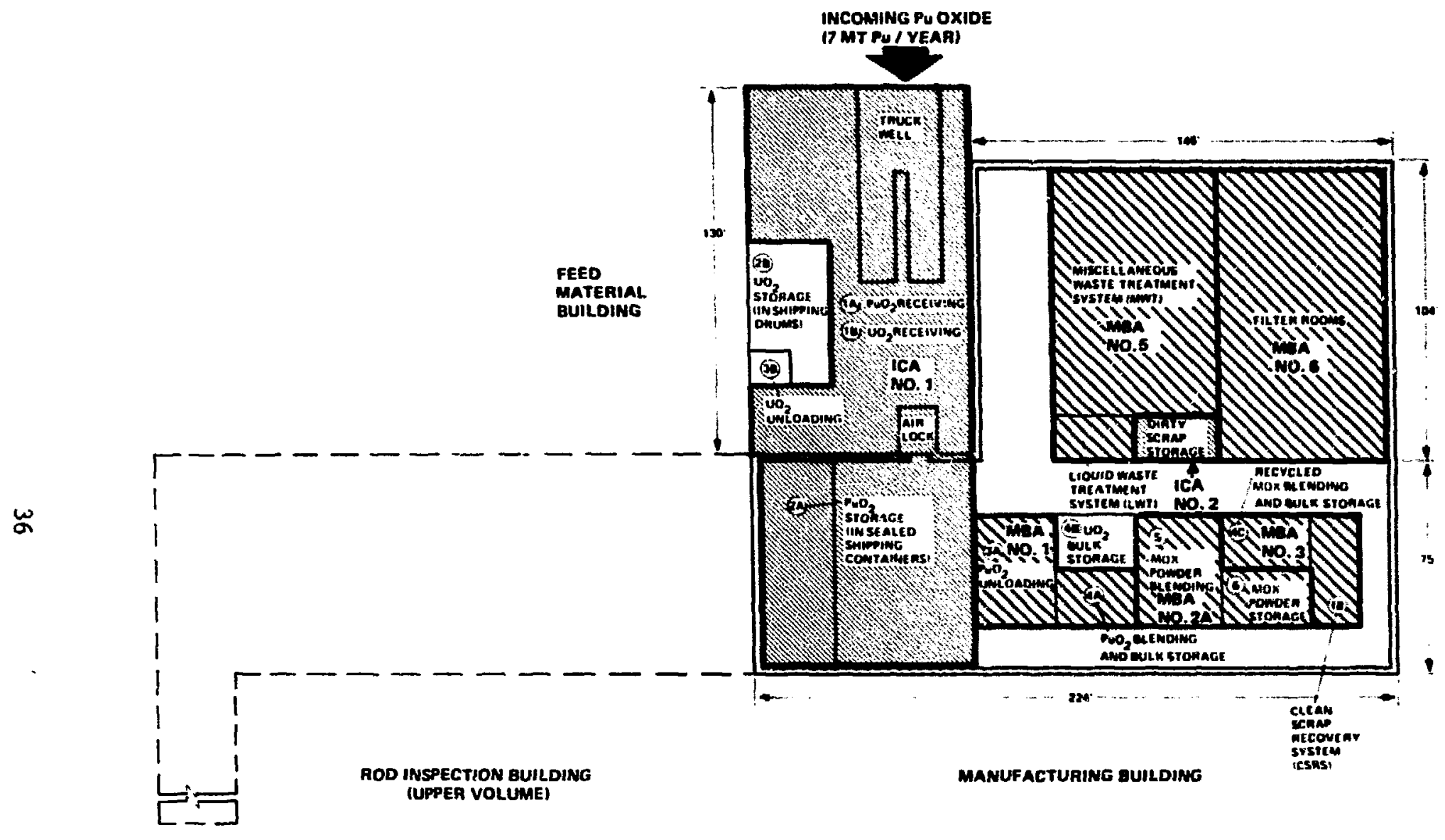

Figure 14.12. MBA and ICA for Second Floor Level of $\mathrm{MO}_{2}$ Fuel P1ant 


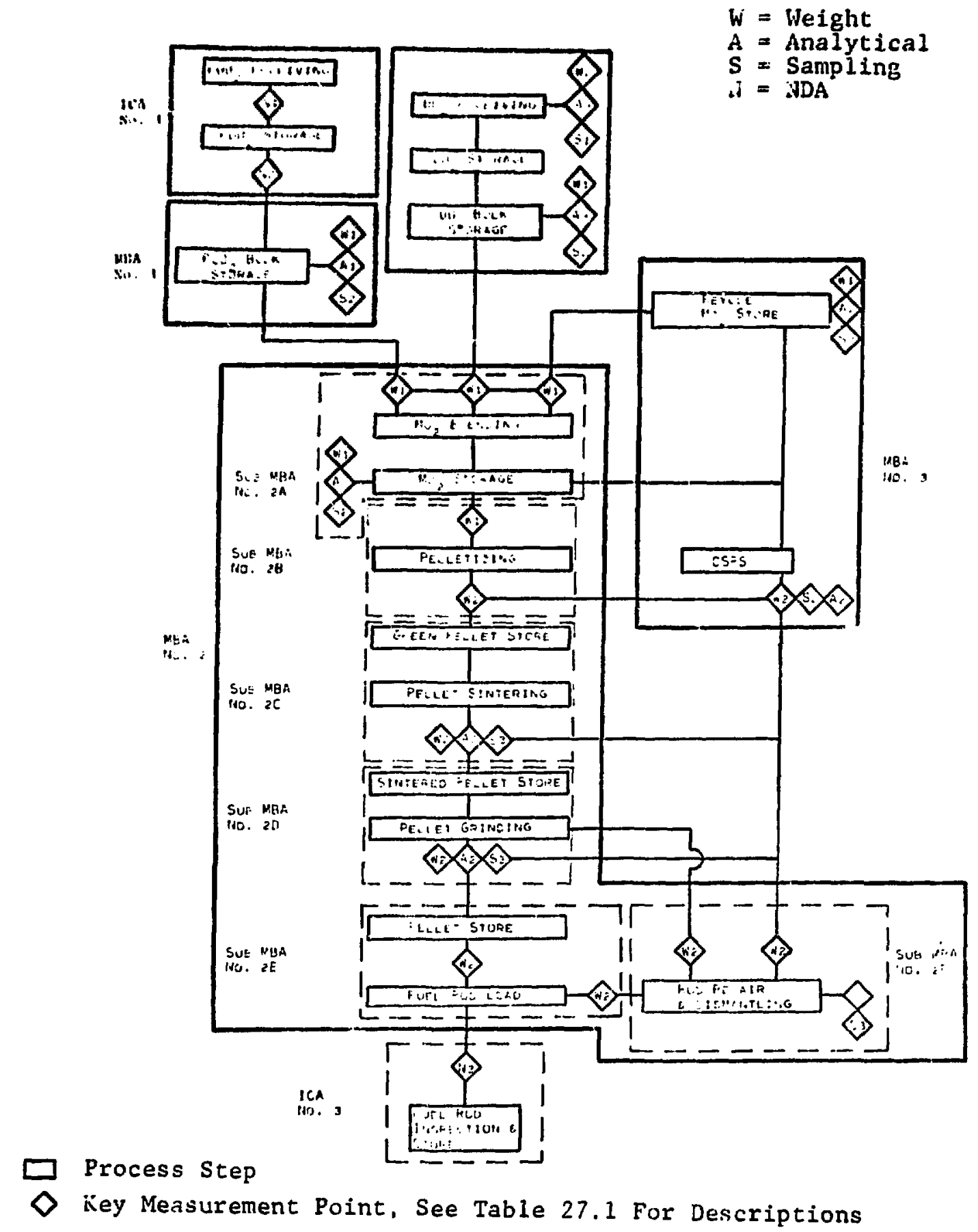

Figure 14.13. Key Measurement Points for a Mixed Oxide Recycle Fuels Plant 
WASTE AND DIRTY SCRAP FLOW FOR $\mathrm{MO}_{2}$ FUEL PLANT

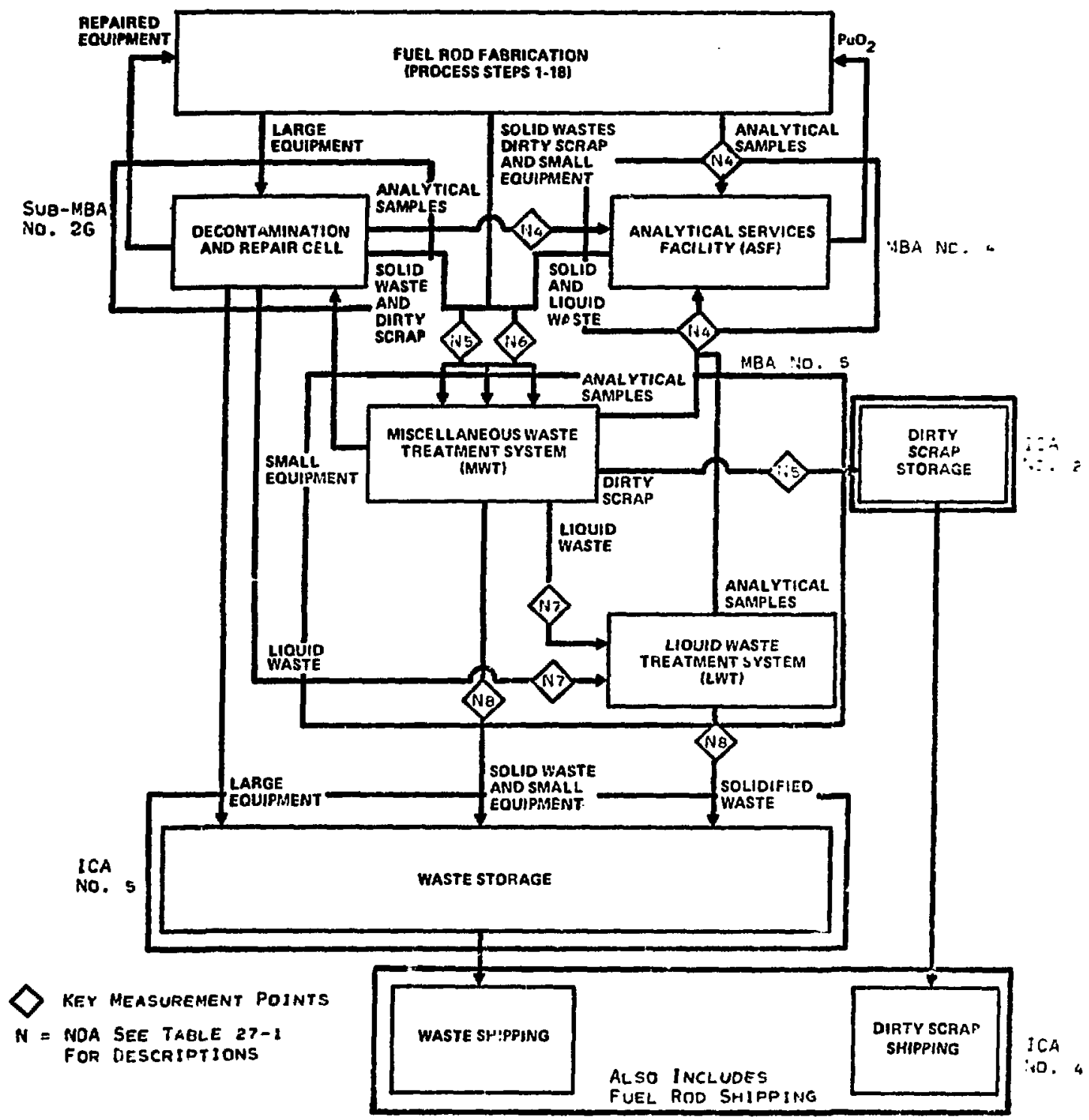

Figure 14.14 Key Measurement Points for A Mixed-oxide Recycle Fuels Plant - Scrap and Waste Processing 
in Section 27 of this DIQ. Storage points in the process are identified in Figs. 14-1 and 14-2 and storage locations are shown in Figs. 14-11 and 14-12. Storage inventories are discussed in Section 17 (iv) of this DIQ.

15. Design Capacity

The licensed capacity of the plant is 6,000 kilograms of plutonium, $10 \mathrm{kilograms}$ of enriched uranium at less than 5 wt $\% U-235$, and 350 grams of high enricned uranium. Typical inventories are 1,000 kilograms of plutonium for 200 MT of mixed oxide per year or 2,000 kilograms of plutonium when operating at maximum throughput of $400 \mathrm{MT}$ per year. Production is planned for 100,000 fuel rods per year, expandable to $200,000 \mathrm{rods} / \mathrm{yr}$.

16. Anticipated Throughput

Throughput is originally planned to be $200,000 \mathrm{~kg}$ of mixed oxide fuel per year at 4 weight $\% \mathrm{PuO}_{2}$. The design is expandable to handle $400,000 \mathrm{~kg}$ per year.

NUCLEAR MATERIAL DESCRIPTION AND FLOW

17. Main Material Description

i. Chemical and Physical Form

Feed is $\mathrm{UO}_{2}$ powder (natural enrichment of U-235) and $\mathrm{PuO}_{2}$ powder (variable isotopic composition).

Product is mixed $\mathrm{PuO}_{2} / \mathrm{UO}_{2}\left(\mathrm{MO}_{2}\right)$ sintered fuel pellets in metal fuel tubes. $\mathrm{PuO}_{2}$ is 4 weight \% of $\mathrm{MO}_{2}$. 
Intermediate Products are mixed $\mathrm{PuO}_{2} / \mathrm{UO}_{2}$ powder, granulated mixed $\mathrm{PuO}_{2} / \mathrm{UO}_{2}$, and unsintered (green) mixed $\mathrm{PuO}_{2} / \mathrm{UO}_{2}$ fuel pellets. $\mathrm{PuO}_{2}$ is 4 weight \% of $\mathrm{MO}_{2}$ in all intermediate product.

Clean Scrap (recycled without purification) consists of off-density green pellets, over-fireci pellets, grinder sludge (dried), inspection reject peilets, and rod repair pellets. All clean scrap is 4 weight $\% \mathrm{PuO}_{2}$.

ii. Throughput.

Average Materials Flows and recycling are shown on an attachment, Fig. 17-1. There is no wet recovery operation for recycle of dirty scrap and waste. These materials are shipped off-site for recovery or disposal.

iii. Batch Size and Campaign Period

Mixed oxide powder is prepared and scored in batches of $225 \mathrm{~kg}$ of $\mathrm{MO}_{2}$ called sub-b lends. Twenty-one of these sub-blends form a complete blend that is determined by exhausting the contents of one $95 \%$ full $\mathrm{PuO}_{2}$ bulk storage vessel and one $96 \%$ full recycled $\mathrm{MO}_{2}$ bulk storage vessel plus the required $\mathrm{UO}_{2}$. Powder pelletizing and fuel rod loading are operated continuously using the $\mathrm{MO}_{2}$ feed on an as required basis. Each sub-blend is made into pellets at an average rate of one sub-blend per shift with a blend being completed in approximately 


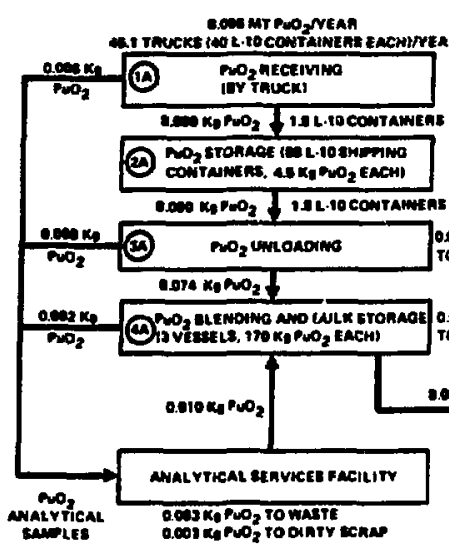

\subsection{MT UO, NEAR} 19.1 FAUCKS DODNUESEACHIYEAA

(1) $\mathrm{N}_{2}$ necEIvimo

1020 K1 $\mathrm{WO}_{2}$, $0.700 \mathrm{num}$

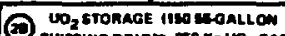

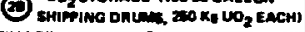
$103.8 \mathrm{~K}_{6} \mathrm{UO}_{2}$, 0.76 DHum

(9) $\mathrm{No}_{2}$ umiandino $103 \mathrm{Kg}_{\mathrm{O}} \mathrm{NO}_{2}$

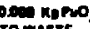
To maste

anderas

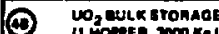
11 HOWER, $3000 \mathrm{Kn}$ UO $103.0 \mathrm{~K}_{1} \mathrm{OO}_{2}$

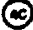

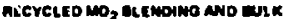
TOMAGE to Veatels, $730 \mathrm{~K}, \mathrm{MO}, \mathrm{EACH})$ $0.00 \operatorname{man}_{2}$

$\mathrm{CaO} \mathrm{K}_{1} \mathrm{PNO}_{2}$

a) $x, 100$.

$0.1 \mathrm{~kg} \mathrm{MO}_{2} \mathrm{ro}$

$0.1 \mathrm{Kang}_{2}$

(3)

MO, HOMOEh alenvinc

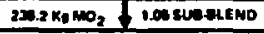

$11.2 \mathrm{Kg}$ MO, USUE IIENO

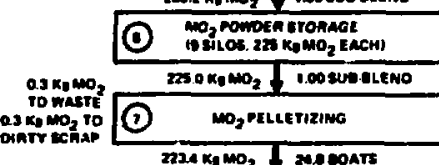

AMMEK)

serves

I WE TRIE TOM (MT) - 1000K

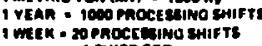

i hater fon

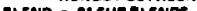

1 eut int

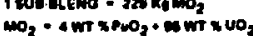

PELLET - $10 \mathrm{gmo}$

I FUEL MOO - 200 PLLLT

- 3 ky

I fuel noo shinimo contalmen

- chamel

- cos rutel nodo

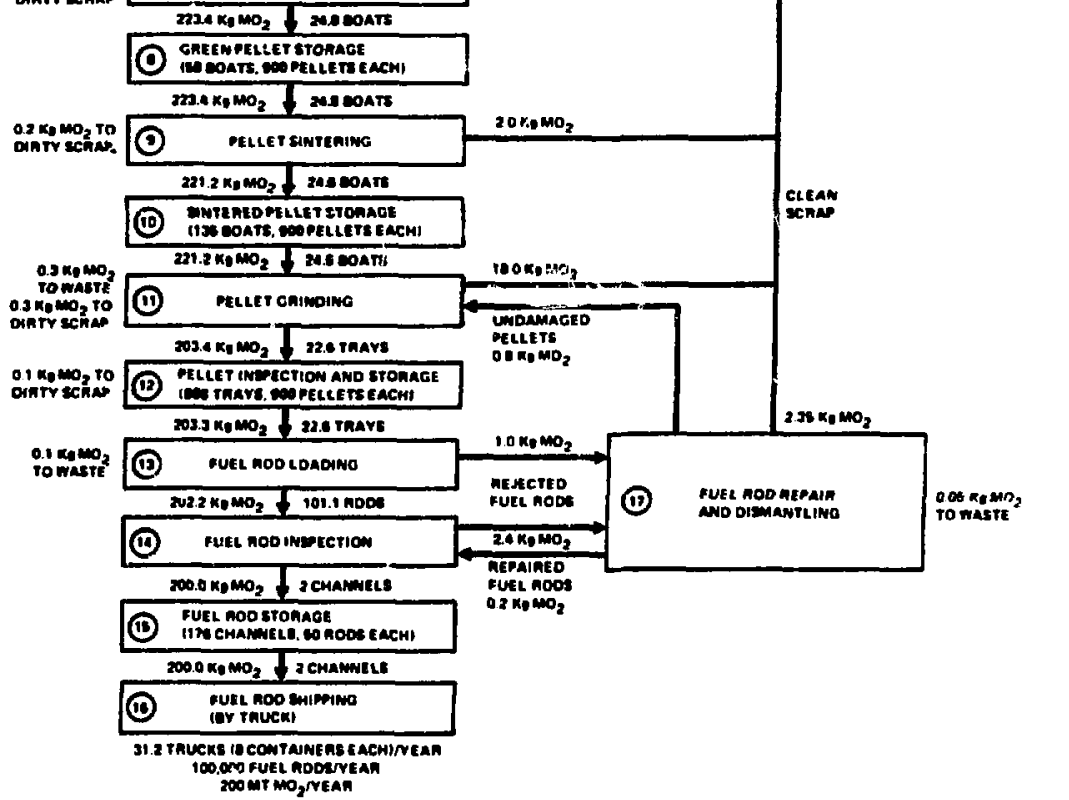

Figure 17.1. Average Material Flow Per 8-Hour

Shift for $\mathrm{MO}_{2}$ Fuel $\mathrm{F}$ ' int 
seven days or twenty-one shifts. Following completion of the blend the process is runout in a sequential manner so that only one stage of the process is down at a single time. Feed for the next mixed-oxide blend is introduced to the $\mathrm{MO}_{2}$ blending step immediately following runout of the blender unless a material cleanout is required because of a plutonium isotopic change or for a physical inventory. A cleanout takes place in a sequential manner similar to a runout, the difference being the extent to which the hold up is cleaned from the process equipment. A material balance around a number of blends or around a compaign (a number of blends with a common attribute) consisting of a single plutonium isotopic composition is therefore easily conducted in a dynamic fashion rather than by a complete shutdown of the entire process a single time for a physical inventory.

\section{iv. Storage Inventory}

Storage inventory capacities are presented in Fig. 17-1 and Table 19-1. An estimate of the average inventory for each stage of the process is presented in attachments, Fig. 17-2 and Tables 17-1. This inventory listing is based on an assumption of $50 \%$ utilization of item storage and $67 \%$ utilization of the capacity of bulk storage vessels. Material inventories following a cleanout are given in Fig. 17-3 and rables 17-1. The dynamic inventory is conducted by introducing a blank or cleanout pulse at the $\mathrm{MO}_{2}$ blending step immediately after emptying a $\mathrm{PuO}_{2}$ and recycle $\mathrm{MO}_{2}$ storage vessel. The inventories at time $\mathrm{T}_{0}$ refer to the time just prior to this cleanout. Approximately $887.2 \mathrm{~kg}$ of plutonium or $75 \%$ of the total plant inventory is in a measureable form that 
TABLE 17-1a. Average Pu Inventories (in $\mathrm{Kg}$ )

$\mathrm{PuO}_{2} \mathrm{~L}-10$ Storage $\mathrm{PuO}_{2}$ Bulk Storage Recycle $\mathrm{MO}_{2}$ Bulk Storage $\mathrm{HO}_{2}$ Blending $\mathrm{MO}_{2}$ Bulk Storage $\mathrm{MO}_{2}$ Pelletizing Green Pellet Storage Pellet Sintering f Sintered Pellet Storage $\omega$ Pellet Grinding Pellet Inspection \& Storage Fuel Rod Loading Fuel Rod Inspection Fue1 Rod Repair Fuel Rod Storage Clean Scrap Recovery MWT

LWT

Analytical Services Dirty Scrap Waste Storage

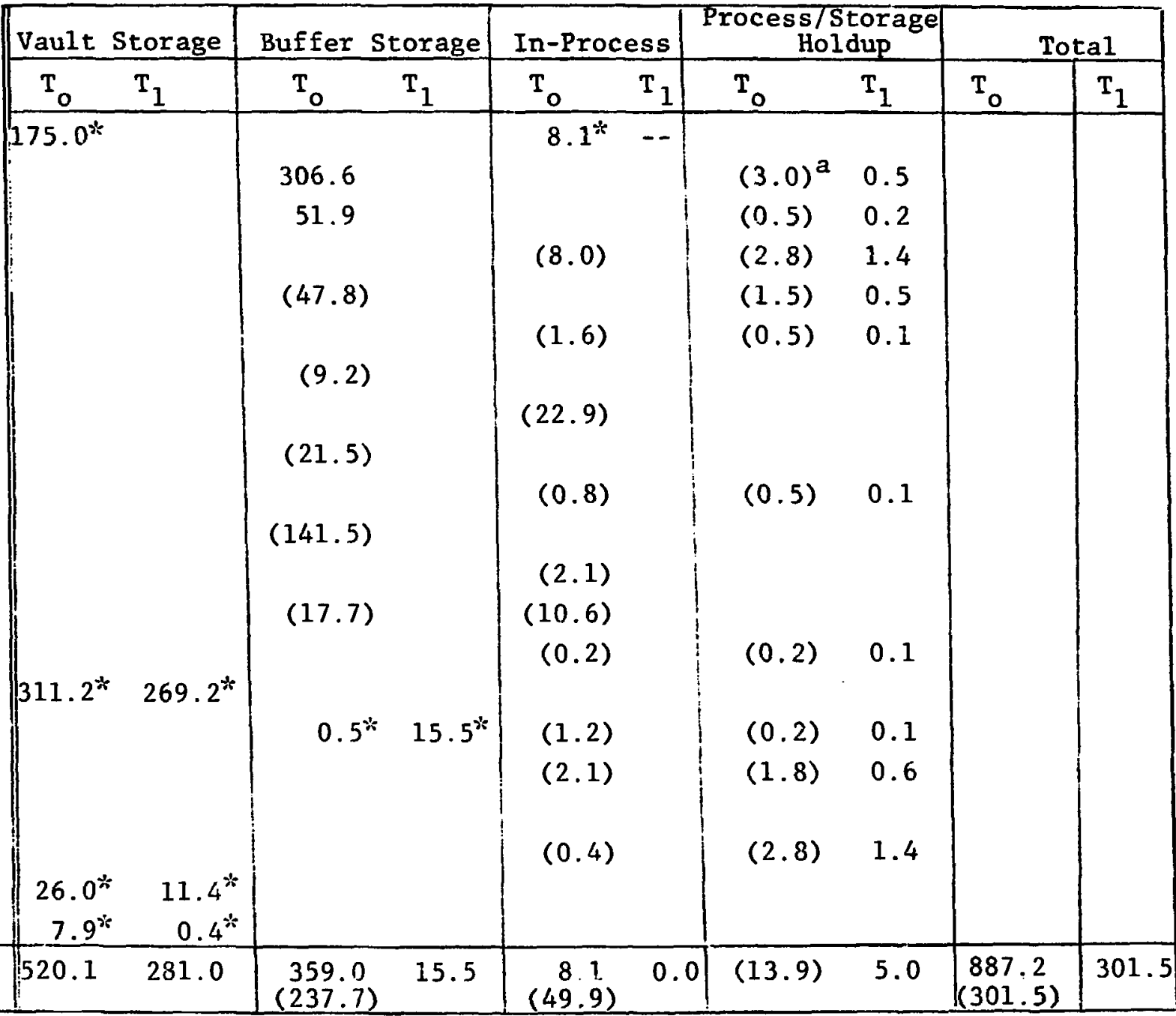
TOTAL

* Sealed items. (a) Parentheses denote material not accounted for at time $T_{0}$. 
TABLE 17-Ib. Average Uranium Inventories (in $\mathrm{Kg}$ )

$\mathrm{UO}_{2} 55$ Gaj.lon Drum Storage $\mathrm{UO}_{2}$ Bulk Storage Recycle $\mathrm{MO}_{2}$ Bulk Storage $\mathrm{MO}_{2}$ Blending $\mathrm{MO}_{2}$ Bulk Storage $\mathrm{MO}_{2}$ Pelletizing Green Pellet Storage Pellet Sintering Sintered Pellet Storage Pellet Grinding Pellet Inspection and Storage

Fuel Rod Loading Fuel Rod Inspection Fuel Rod Repair Fuel Rod Storage Clean Scrap Recovery MWT

LWT

Analytical Services Dirty Scrap Waste Storage

TOTAL

Sealed items.

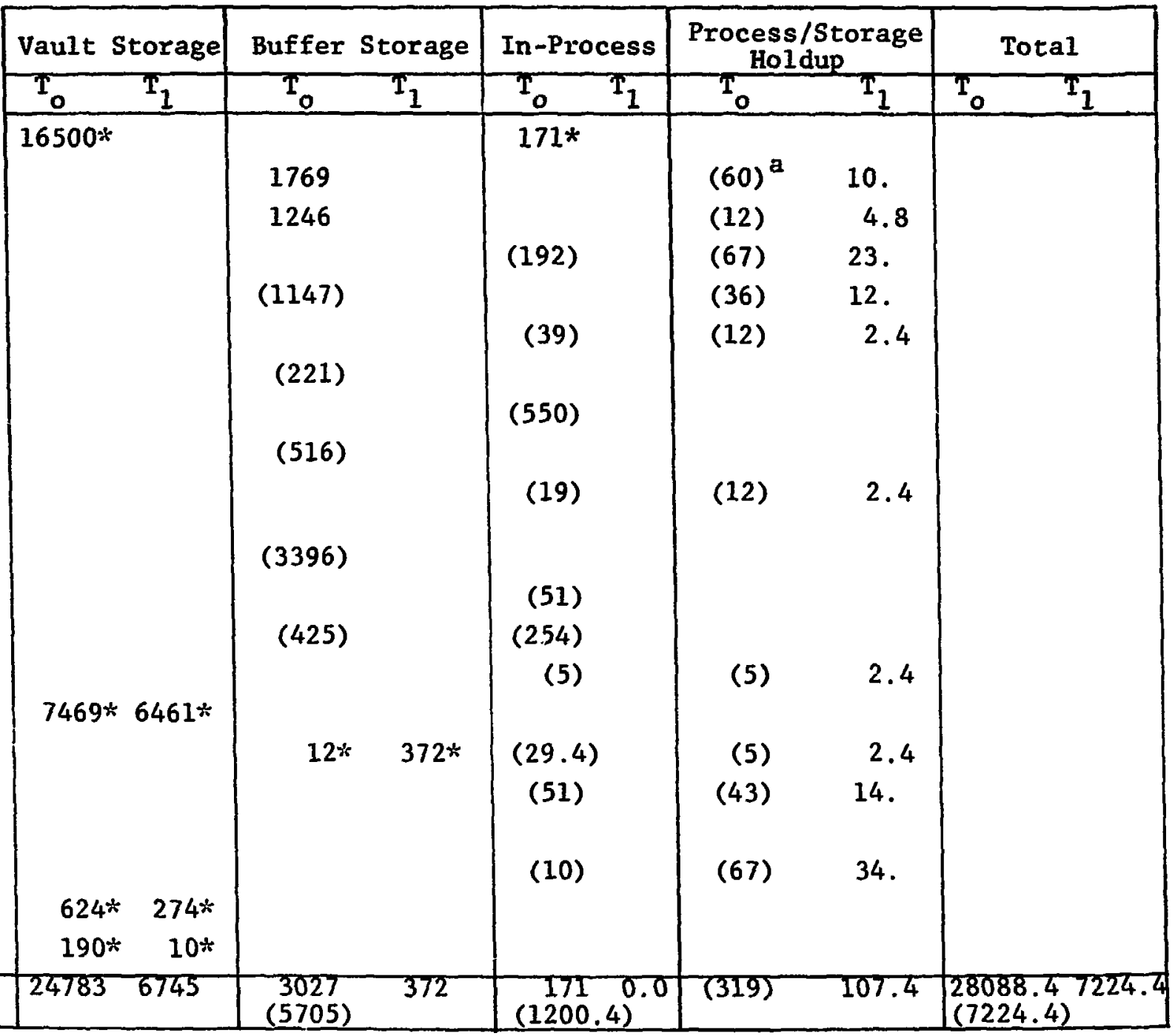

\footnotetext{
${ }^{a}$ Parentheses denote material not accounted for at time $T_{0}$.
} 


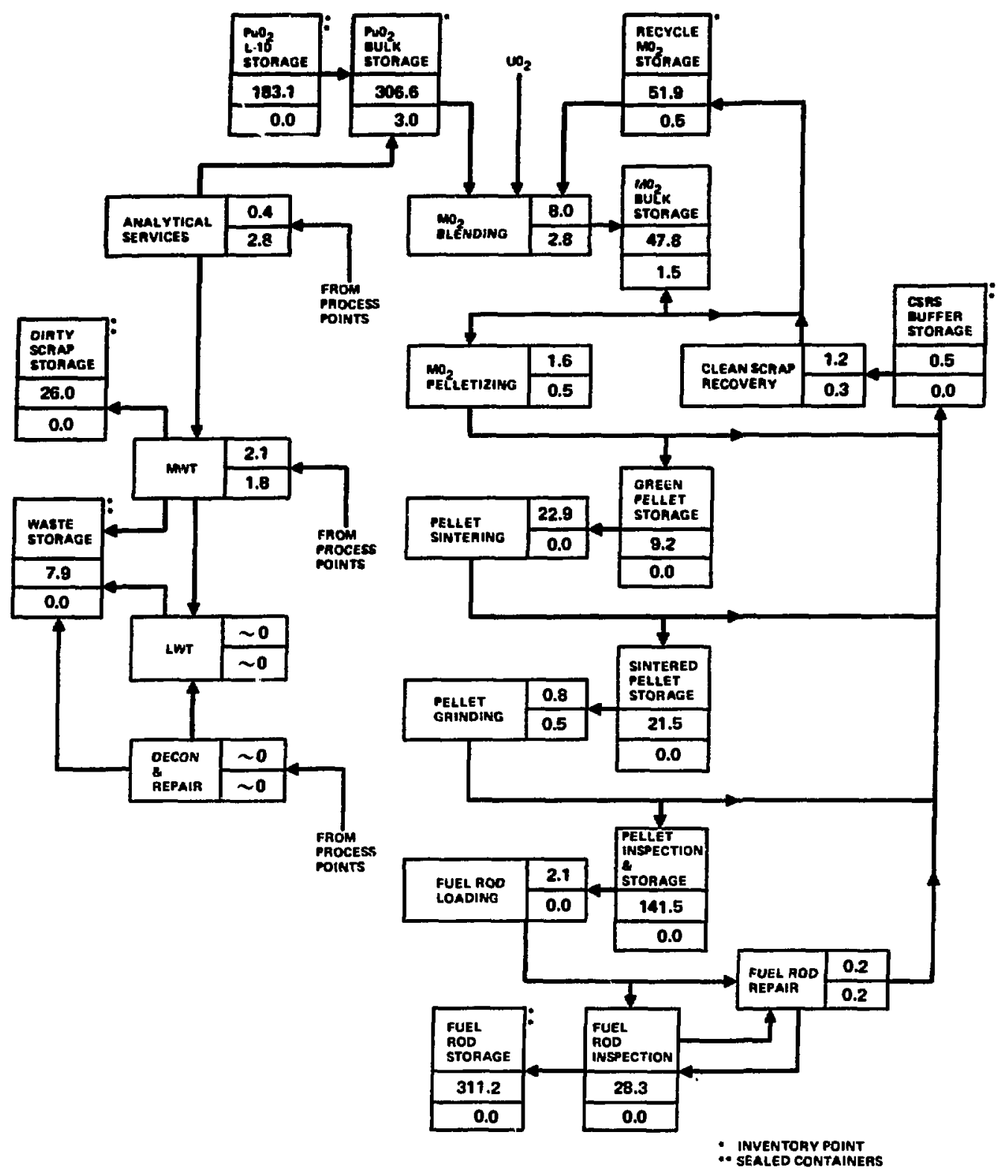

KEY:
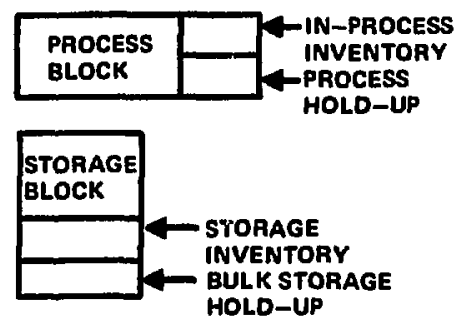

INVENTORY (kg Pu)

SEALED ITEMS (-4) 628.7 MEASURED BULK STORAGE (") ;:58.5 TOTAL ACCDUNTABLE IN-PROCESS 39.3 BUFFER STORAGE 248.3 HOLO-UP 13.9 TOTAL NON-ACCOUNTABLE

TOTAL

1188.7

Figure 17.2. Plant Inventory ( $\mathrm{Kg}$ of $\mathrm{Pu}$ ) at Time $\mathrm{T}_{0^{--}}$ Immediately Following Emptying of One of the $\mathrm{PuO}_{2}$ and Recycle $\mathrm{MO}_{2}$ Storage Vessels 


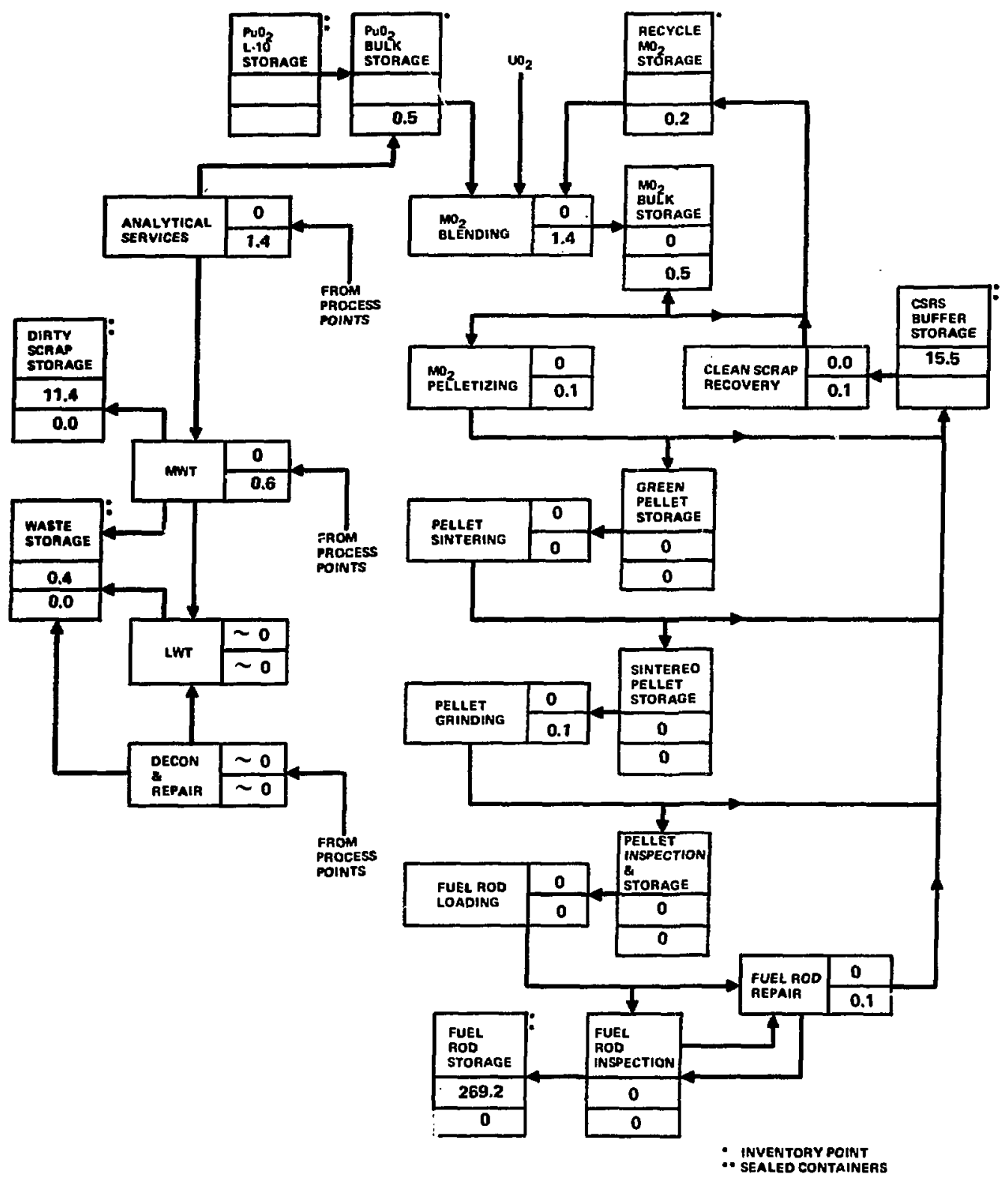

KEY:

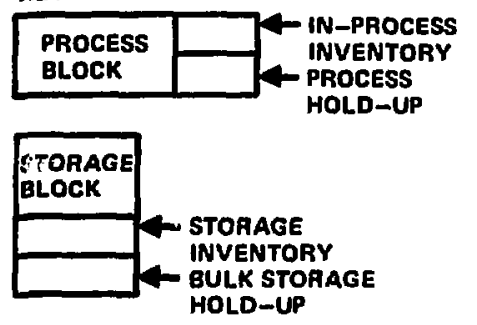

INYENTORY

SEALED ITEMS $\quad 296.5$

MEASURED BULK STORAGE $\quad 0.0$

HOLD-UP

TOTAL

5.0 (SURVEY)

Figure 17.3. Inventory ( $\mathrm{Kg}$ of $\mathrm{Pu}$ ) at Time $\mathrm{T}_{1}$ - After Cleanout (Only Material Non-accountable at $T=T_{0}$ is Shown) 


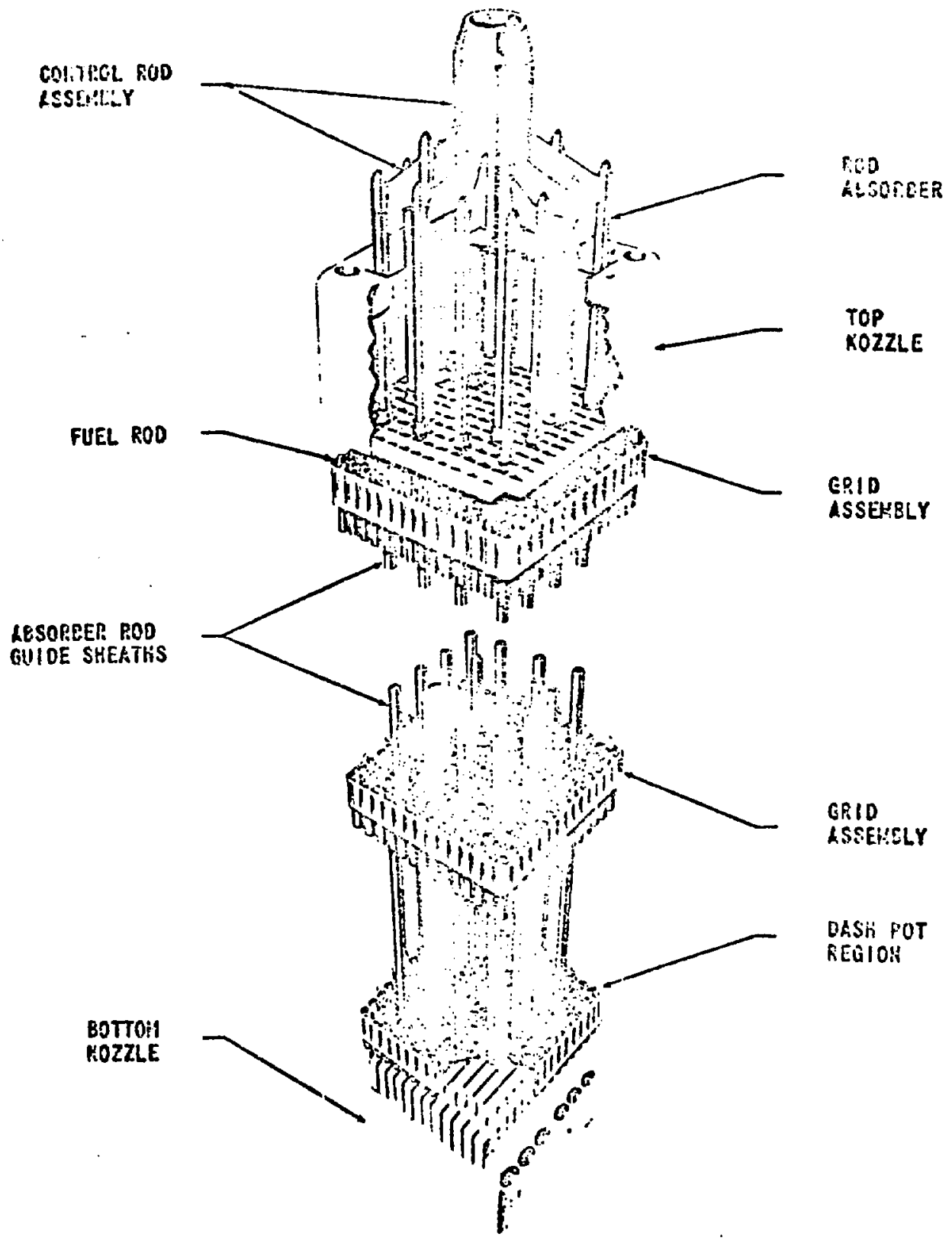

Figure 17.4. Typical Rod Cluster Control (RCC) Assembly for the Zion Station Reactor 


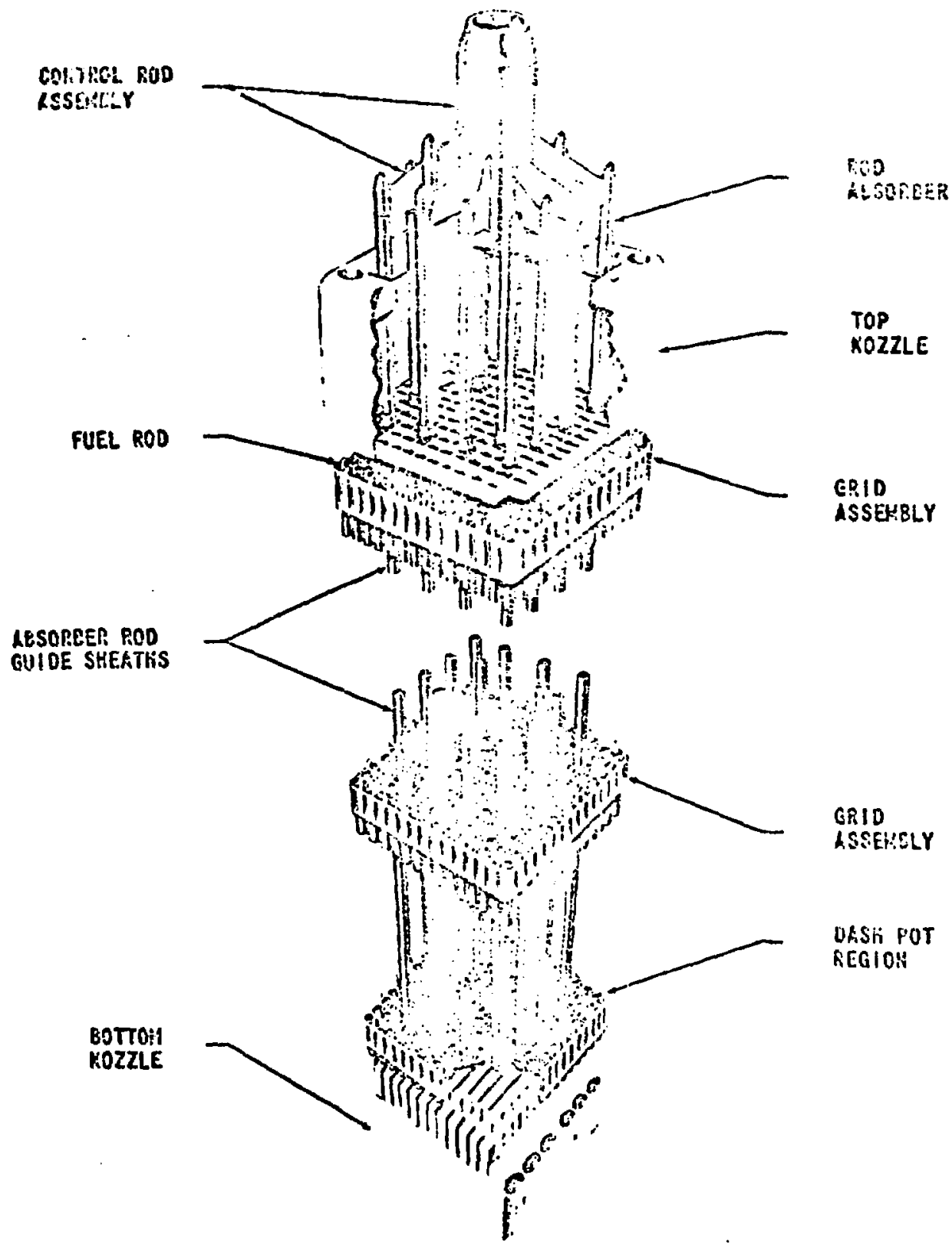

Figure 17.4. Typical Rod Cluster Control (RCC) Assembly for the Zion Station Reactor 


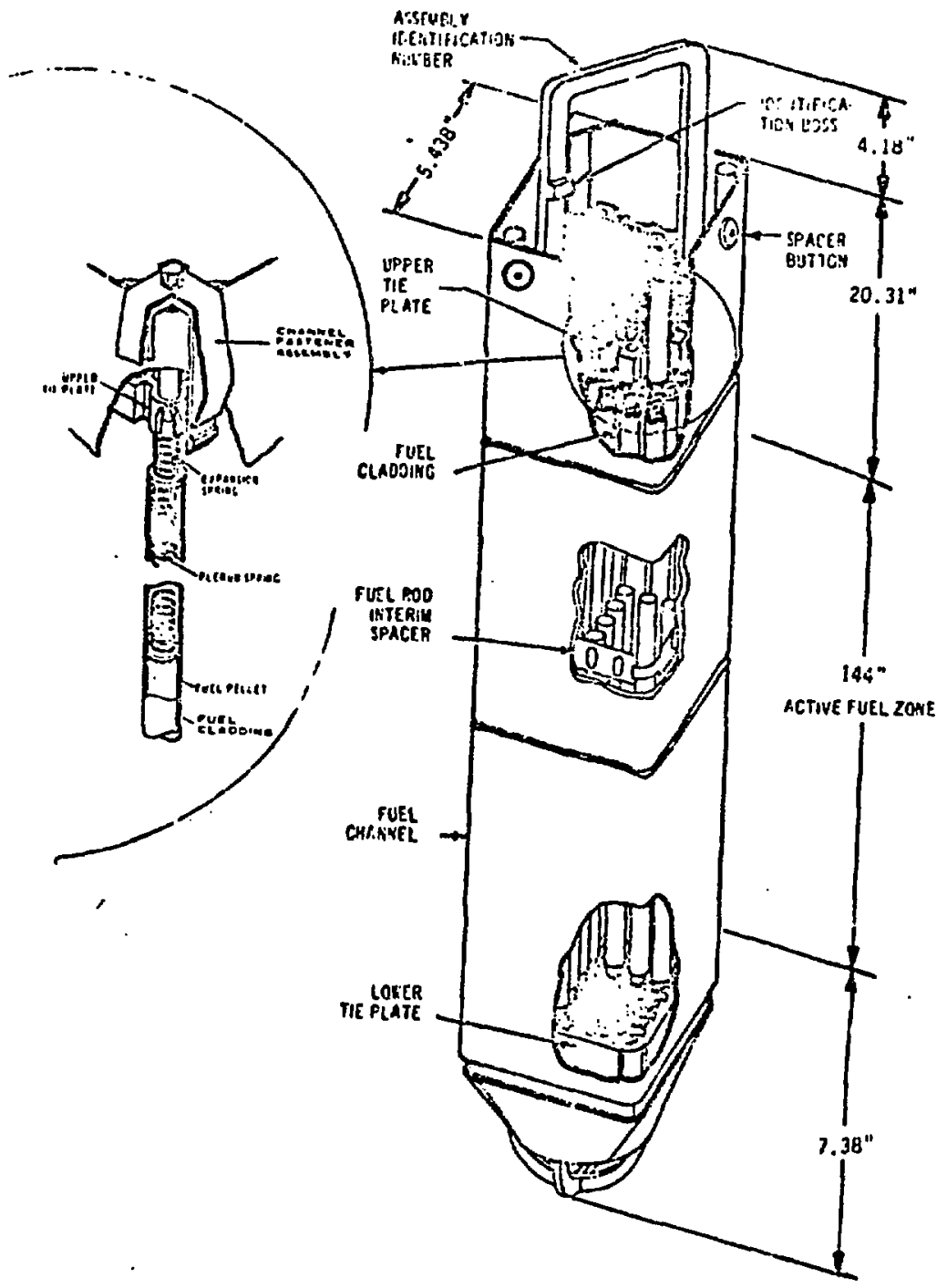

Figure 17.5. Isometric View of Typical Fuel Element of Browns Ferry Reactor 
can be verified at time $\mathrm{T}_{0}$, i.e., as sealed items or in bulk storage vessels attached to load cells, having sampling lines, and having a gamma-ray scanning mechanism. The remaining 301.5 kilograms or $25 \%$ of inventory is eithar in-process or in buffer storage. As the blank or cleanout pulse moves through the process, clean scrap, dirty scrap, waste, and finally product generated ahead of the pulse are segregated from other material already inventoried at time $\mathrm{T}_{0}$. After the cleanout of the final step the segregated materia $i$ is inventoried and added to the inventory at time $T_{0}$. This final inventory is conducted at a time $\left(T_{1}-T_{0}\right)$ after $T_{0}$ that is equal to the residence time of material in the process*. Figure 17-3 and Table 17-1 show the final distribution, at time $T_{1}$, of the material in-process or buffer storage at time $T_{0}$. The cleanout pulse lasts approximately 3-6 shifts at each process step, after which material is reintroduced at that stage of the process.

v. Frequency of Receipt or Shipment

Receipts and shipments are scheduled to meet a throughput of $200 \mathrm{Mr}$ of $\mathrm{MO}_{2}$ per year. Approximately 45 truckloads of $\mathrm{PuO}_{2}$ and 11 truckloads of $\mathrm{UO}_{2}$ are received and 31 truckloads of rods are shipped per year.

*This residence time is approximately 60 shifts or 20 days to move from $\mathrm{MO}_{2}$ blending to fuel rod storage. This time can be reduced to approximately 18 shifts or 3 days if pellets are accounted for at the pellet inspection and storage point just prior to fuel rod loading. 
18. Waste Material

See attachments, Figs. 20-2 and 20-3 and Table 18-1.

19. Containers and Storage Area Description

See attachment, Table 19-1

20. Recycle Processes

The clean scrap recovery system is described in Fig. 20-1. Sources of clean scrap are indicated on this figure. The main source, grinder sludge, accounts for $86 \%$ of clean scrap. Clean scrap is processed in 20 kilogram $\mathrm{iO}_{2}$ batches and recycled through recycle $\mathrm{MO}_{2}$ blending and storage to the $\mathrm{MO}_{2}$ blending step. Inventories and storage are described in items (17), and (19) of this DIQ.

The Miscellaneous Waste Treatment (MWT) system is described in Fig. 20-2. Sources of this waste exist throughout the plant. Dirty scrap and waste are stored in vaults until shipment and ar chen shipped off-site. Inventories and storage are described in items (17), and (19) of the DIQ.

The Liquid Waste Treatment (LWT) system is described in Fig. 20-3. Liquid waste accounts for a small volume of waste and contains very low concentrations of plutonium.

21. Measured Discards and Retained Waste.

Waste is generated at a rate of approximately 53 grams of plutonium per shift or $0.7 \%$ of the plant throughput. Dirty scrap is generated at a rate of approximately 43 grams of plutonium per shift or $0.5 \%$ of the plant throughput. The majority of the waste is 
TABLE 18-1. C1ean Scrap, Dirty Scrap, and Waste Generation at a $200 \mathrm{MT} /$ Year $\mathrm{MO}_{2}$ Fabrication Plant.

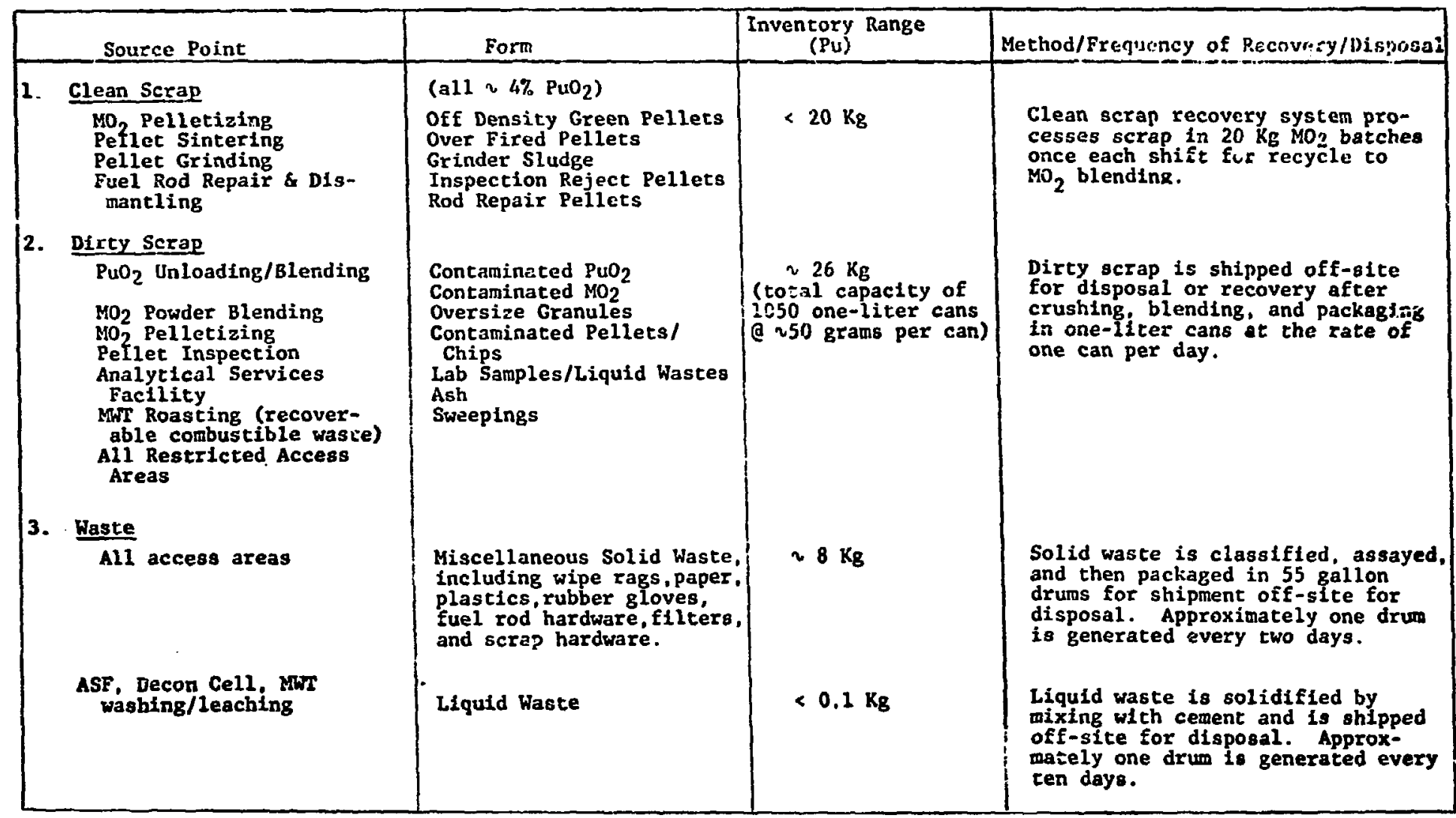


TABLE 19-1. Containers and Storage Areas for a $200 \mathrm{MT} / \mathrm{Yr} . \mathrm{MO}_{2} \mathrm{Plant}$

\begin{tabular}{|c|c|c|c|}
\hline Container Type & $\begin{array}{l}\text { Naterial Forms } \\
\text { (content) }\end{array}$ & Storage Method & Srorage Area (capacity) \\
\hline L-10 shipping & $\mathrm{PuO}_{2}(4.5 \mathrm{Kg})$ & Sealed Containers/Vault & $\mathrm{PuO}_{2}$ Storage, ICA-1 (88) \\
\hline Storage Vessels & $\begin{array}{l}\mathrm{PuO}_{2}(170 \mathrm{Kg}) \\
\mathrm{MO}_{2}(720 \mathrm{Kp})\end{array}$ & $\begin{array}{l}\text { Bulk Storage/icad Cell } \\
\text { Bulk Storagc/Load Cell }\end{array}$ & $\begin{array}{l}\mathrm{PuO}_{2} \mathrm{Blending/Storage} \mathrm{(3)} \\
\text { Recycle } \mathrm{MO}_{2} \text { Blending/Storage } \\
\text { (3) }\end{array}$ \\
\hline Storage Silos & $\mathrm{MO}_{2}(225 \mathrm{Kg})$ & Bulk Storage & $\mathrm{MO}_{2}$ Storage $(9)$ \\
\hline Storiage Hoppers & $\mathrm{vO}_{2}(3000 \mathrm{Kg})$ & Bulk Storage/Load Cell & $\mathrm{UO}_{2}$ Bulk Storage (1) \\
\hline Green Pellet Boats & Green Pelleis $(900)$ & $\begin{array}{l}\text { Sealed Containers/Shielded } \\
\text { Buffer Sturilge }\end{array}$ & Green Pellet Storage (58) \\
\hline Sintered Pellet Boats & Sintered Pellets $(900)$ & $\begin{array}{l}\text { Sealed Containers/Shielded } \\
\text { Buffer Storage }\end{array}$ & Sintered Pellet Storage (135) \\
\hline Pellet Trays & Final Pellets $(900)$ & $\begin{array}{l}\text { Sealed Conlainers/1 of } 2 \\
\text { Shielded Buffer Storage Areas }\end{array}$ & Pellet Storage/Inspection, (888) \\
\hline Channels & Fuel Rods (50) & Sealed Containers/Vitult & Fucl Rod Storage, (176) \\
\hline One-Liter Cans & Clean Scrap & Sealed Containers/Buffer Storage & $\begin{array}{l}\text { CSRS. Pelletizing, } \\
\text { Sintering, Grinding, Rod } \\
\text { Repilir (so) }\end{array}$ \\
\hline Onz-I.iter Cans & Dirty Scrap \& Ash & Sealed Concainers/Vault & $\begin{array}{l}\text { Dirty Scrap SLorage }(1050) \\
M W T(35)\end{array}$ \\
\hline One-Gallon Cans & Solid Waste & Sealed Containers/Bufer Storage & MWT and Throughout the Plant \\
\hline Five-Gallon Cans & Sorted Waste for Assay & Senled Contaners/Buffer Storape & $M \sqrt{T}$ \\
\hline 55-Ga11on Drums & Solid/Liquid Waste & Sealed Containers/Vault & Waste Storage (525) \\
\hline
\end{tabular}




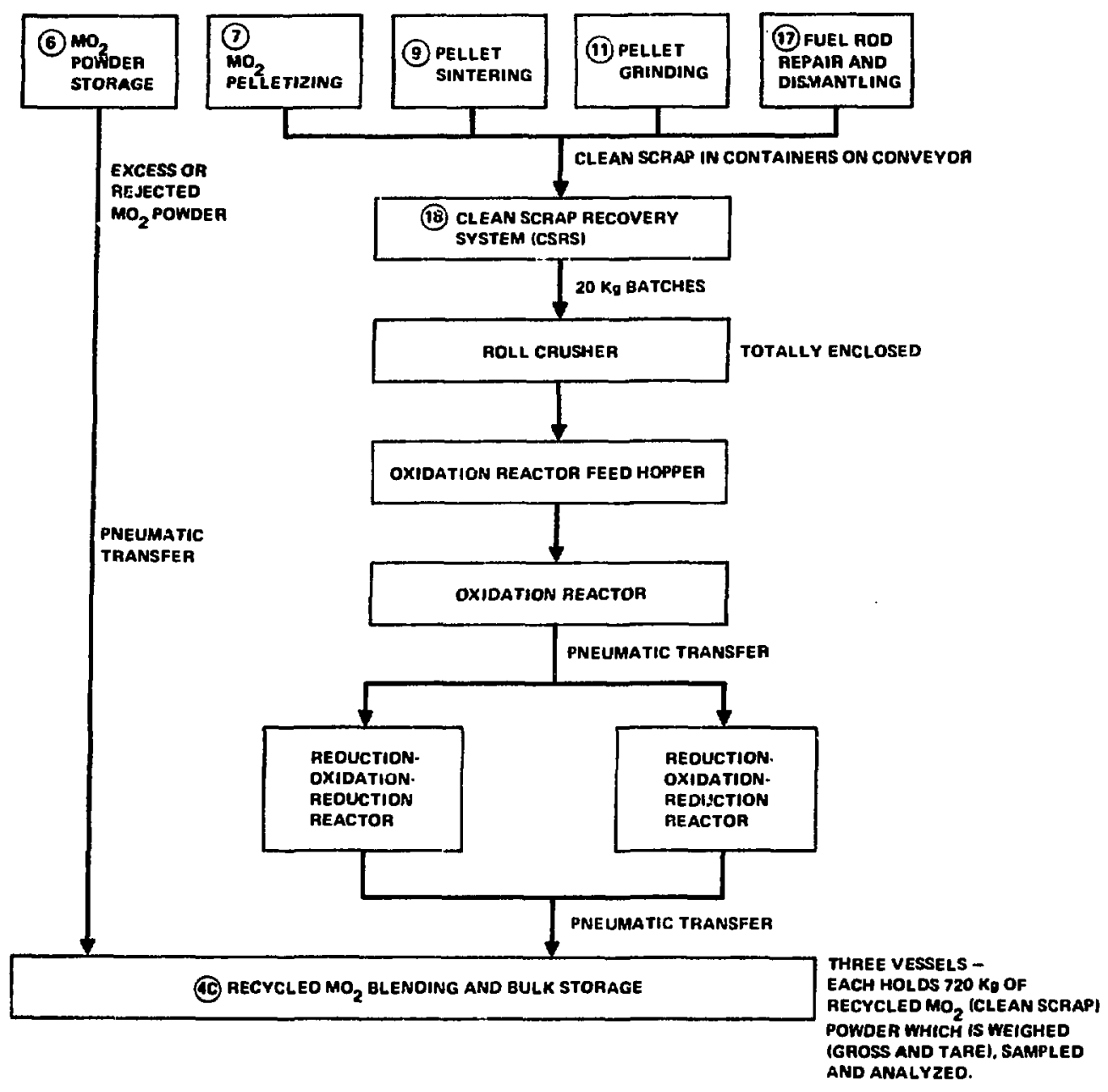

Figure 20.1. Clean Scrap Recovery System (CSRS) 


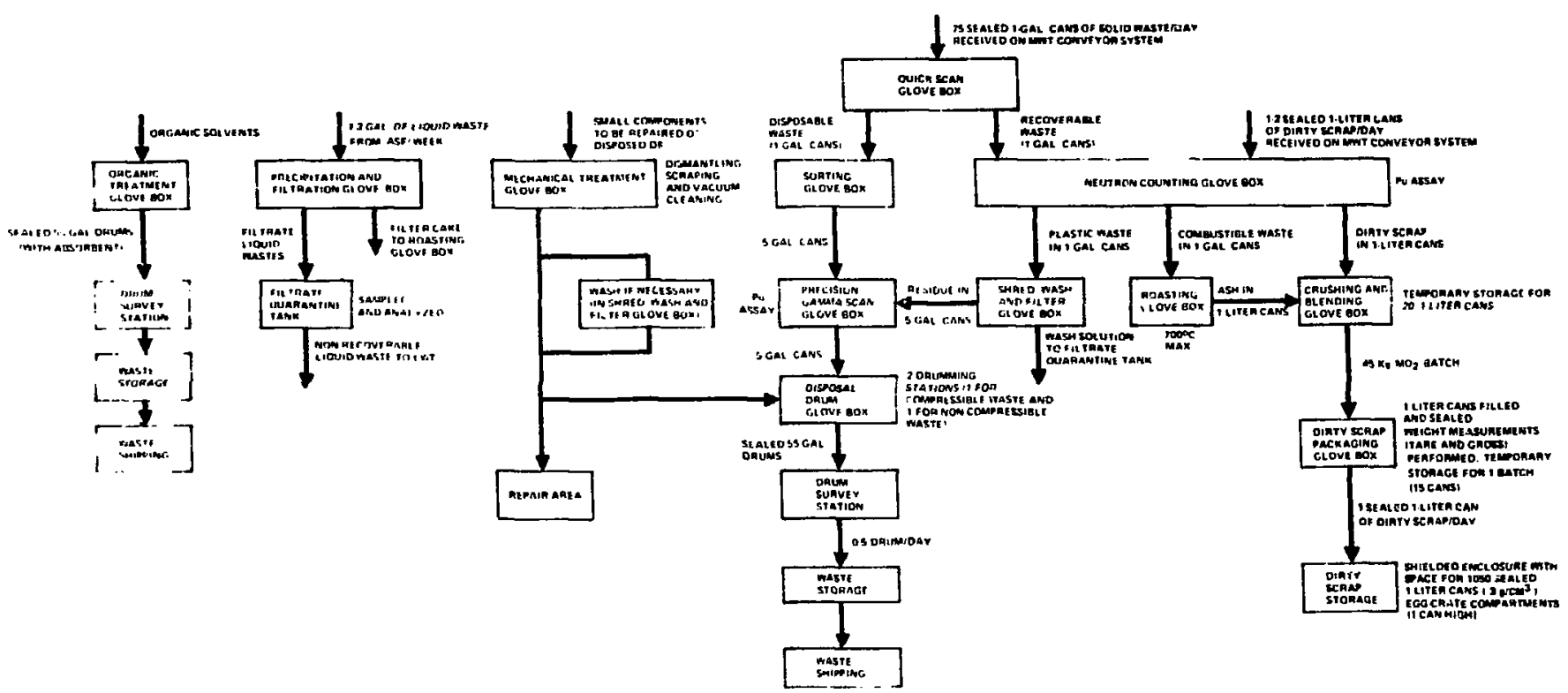

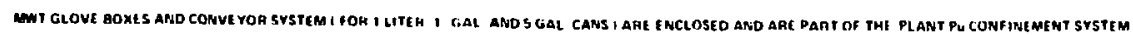

Figure 20.2. Miscellaneous Waste Treatment (MWT) 


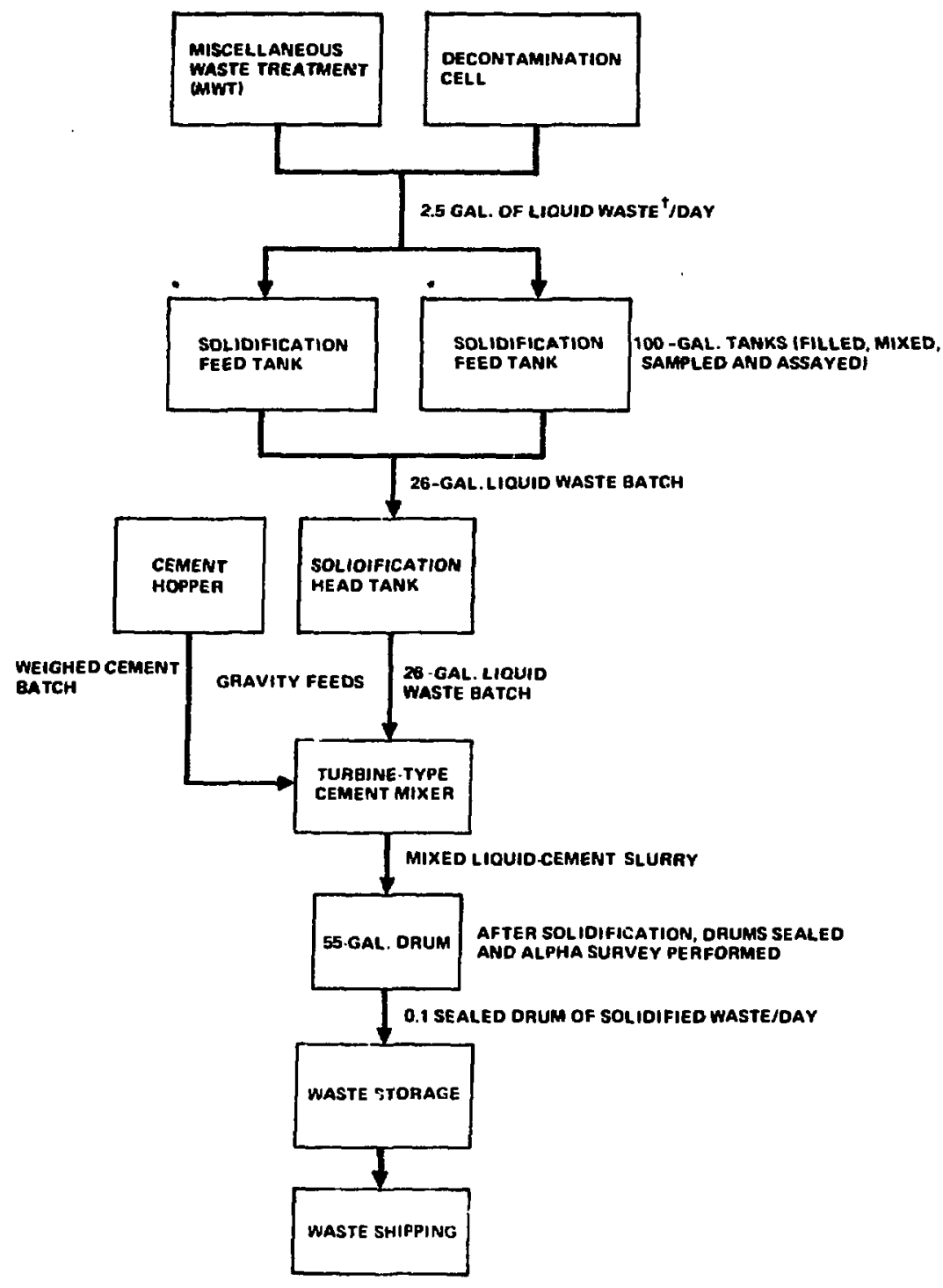

TLIOUID WASTES AAE MIXED. SAMPLEO ANO ASSAYED PRIOR TO TRANSFER TO LWT -LIMITED TO 290 \& OF Pu

Figure 20.3. Liquid Waste Treatment System (LWT) 
burned to an ash, with the remainder packed into 55 gallon drums at a rate of one every two days. Dirty scrap is packed into 1 -liter cans at a rate of one can per day. The average inventory of dirty scrap is 26 kilograms or $2.2 \%$ of the bimonthly throughput, and the average inventory of waste is 8 kilograins or $0.7 \%$ of the bimonthly throughput.

22. Inventory

See Item 17 (iv) of this DIQ.

PLANT MAINTEINANCE

23. Maintenance, Decontamination and Cleanout

Decontamination of equipment takes place in the Decontamination and Repair Cell which is shown as Attachment 23-1. Plutonium and uranium accumulated during decontamination is treated as waste or dirty scrap, depending on its characteristics. Equipment is emptied, broken down, and cleaned to the extent possible while at its normally installed position. It is then transferred by crane to the Decontamination Cell where it is cleaned by vacuuming, flushing and/or washing with liquids, steain, or compressed air. All operations are remote. After decontamination equipment is repaired and returned to operation or is baggedout and sent to waste storage.

PROTECTION AND SAFETY MEASURES

24. Basic Physical Protection of Nuclear Material

The facility employes a security system which meets present U.S. Nuclear Regulatory Commission regulations covered in Part 73 of Title 10 of the Code of Federal regulations. This security system includes perimeter 


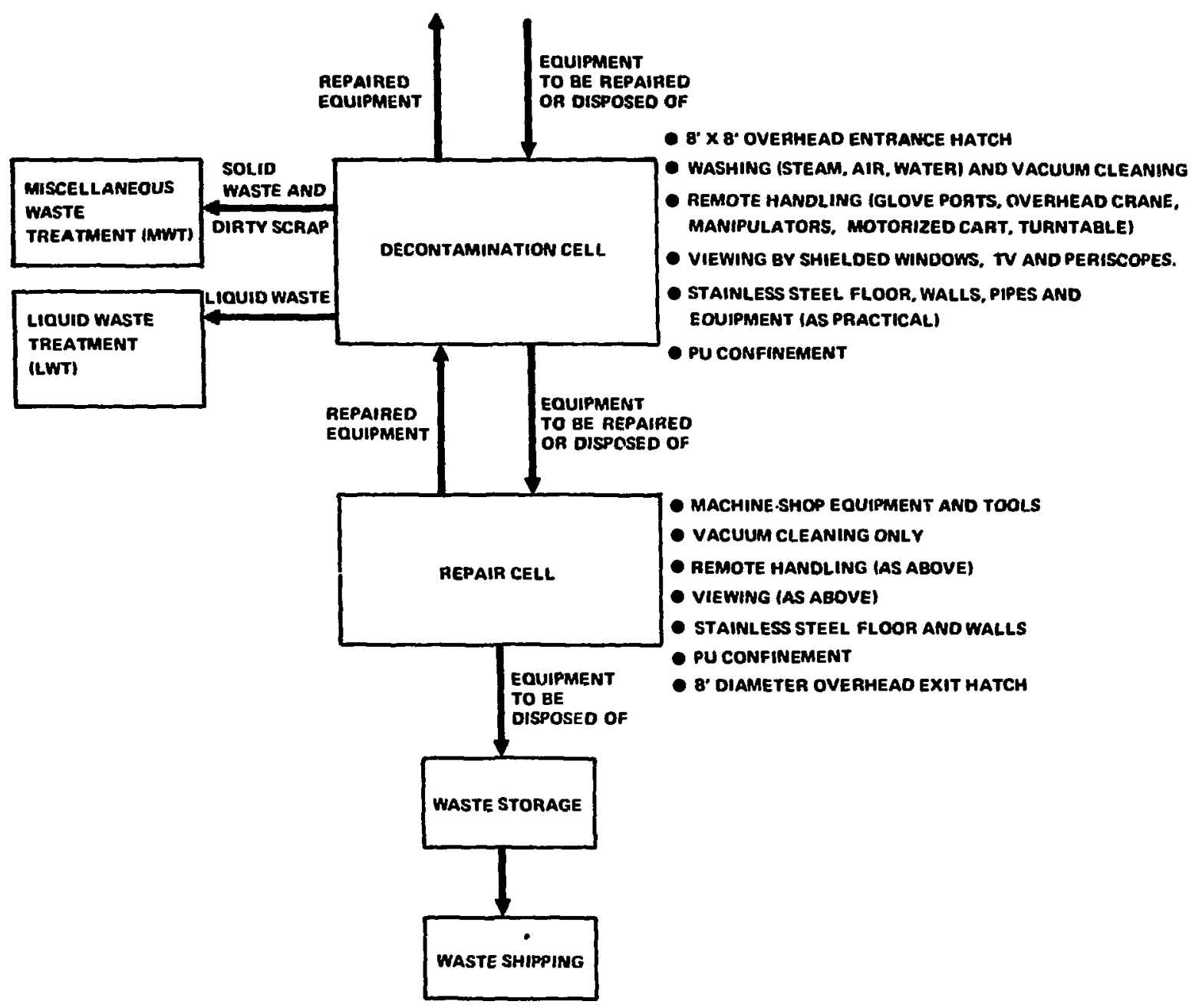

Figure 23.1. Decontamination and Repair Cell 
barriers, a perimeter isolation zone with monitoring, inner barriers, access control and a guard force to monitor security systems, patrol secure areas, and respond to alarms. All visitors must be escorted in material access areas.

25. Specific Health and Safety Rules

The inspectors will be given a health and safety orientation prior to entering areas containing radioactive materials. The inspectors will be escorted at all times by trained employees. The manufacturing area is divided into three access zones, one inside the other. The plutonium is contained in sealed, negative-pressure canyons or glove boxes within the inner zone, called the Restricted Access Area (RAA). The surrounding zone is called the Limited Access Area (LAA) and is used for sampling and maintenance. The outer zone is the Access Area (AA) and is the zone in which the inspectors will spend the majority of their time. Entrance to the (LAA) is controlled and entry for Agency sampling will be reviewed and approved by plant management. No access to the (RAA) should be necessary.

NUCLEAR MATERTAL ACCOUNTANCY

26. System Description

(i) General - The facility utilizes a computerized accountability system for on-line data acquisition and automated record keeping and reporting to monitor the status of plutonium receipts, shipments, and inventory as it arrives, leaves, and is processed through the plant. Each discrete container of material or storage location has a unique identification code. Information is stored in the computorized accountability 
system giving the measured amount of material and its associated error, the measurement method code, the MBA or sub-MBA, and a blend traceability reference identification (usually part of the material identification code). Material transfers can be authorized only by responsible personnel with access to the computor system or by process control computors automatically transferring material through the process. For each transaction between sub-MBA's or MBA's an entry is made into the computer accountability system. These entries are through a combination of remote terminals and on-line sensors interfaced to the computor system. Transfers can also be made through offline entry using a Nuclear Material Transfer form (see attachment Figure 26-1). Data from this form is punched on cards for entry into the computer system.

The functions of the accountability computers are: collection of measurement and measurement control data; conversion of measurement data to accountability quantities (e.g., grams of plutonium) and control data to calibrations, measurement errors and control limits; to store and/or assign identification codes; establish a traceability hierarchy for material in each blend (see attachment Figure 26-2); interrogate the status of storage monitors; perform statistical tests and signal results to the operator (e.g., tests on the acceptability of measurement performance and response that measurements may or may not commence); calculation of inventories and material balances for MBA's and subMBA's; preparation and editing of data files; and preparation of reports in formats required by the facility, the U. S. Nuclear Regulatory Commission (e.g., 741 's and $742^{\prime} s$ ), and the IAEA. 


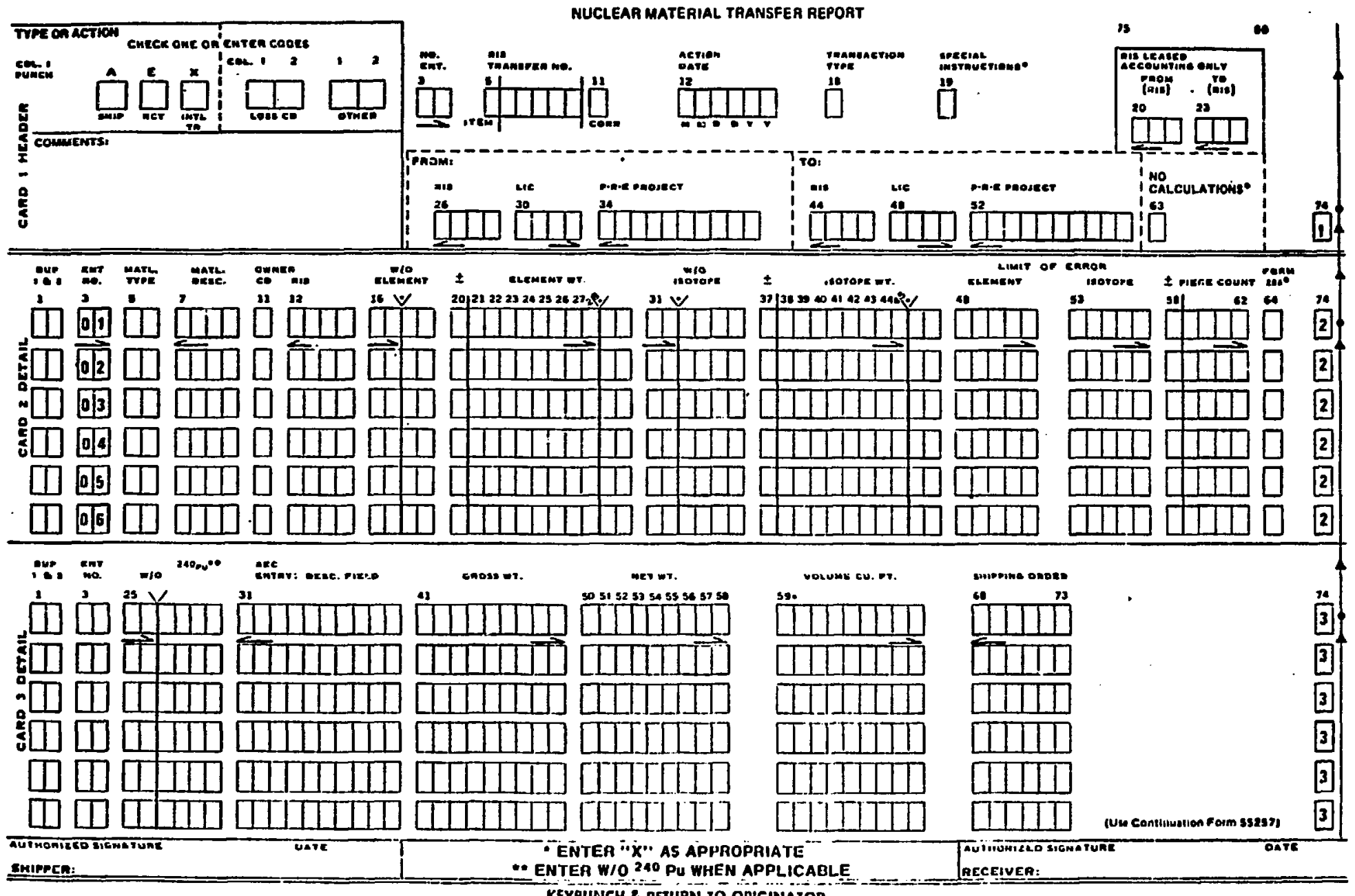
KEYPUNCH a RETURN IO ORIGINATOR

Figure 26.1. 
In routine operation, data entering the computer from on-line sensors is first checked for adequacy, then converted to accounting data and corrected for bias, assigned an error estimate in terms of both total random and total and component systematic errors, and stored with the measurement and material identification code. On-line sensors include identification code readers, weighing devices, samplers, analytical measurements, NDA instruments, seal readers, and holdup monitors. Part or all of the required data may be entered from on-line terminals or off-line through punched cards. Data files are then updated after the transaction has been completed. Summary reports can be generated in hard copy or on CRT's upon request using these data files. For example, upon request the material inventory and a material balance for an MBA can be displayed on a CRT. Included is hold up in process and the measurement status of all material in the MBA. Adjustments can be made to the data through the on-line terminals or through punched cards. A record of all adjustments is maintained showing original and final values and the type and authorization for the adjustment.

(ii) Receipts - Plutonium dioxide is received in L-10 shipping containers and the shippers value, error estimate (if provided), and identification code are entered into the accounting system. An initial gammaray assay is performed as an immediate check on the contents. A seal verification is also performed and recorded. After opening the L-10 containers the cans of $\mathrm{PuO}_{2}$ are removed and each is assayed using nuclear calorimetry. The cans are assigned a facility identification and measured value based on the calorimetric 
assay. Up to this point the material was carried at the shippers value. A shipper/receiver difference (SRD) comparison is made individually on each can and on each shipment. The SRD comparison is described in Section 28. If the SRD is significant and is verified by a second check, the individual outlier cans or the entire shipment is quarantined. The sans still have the shippers seal at this point and a referee is called in to settle the difference. NRC is notified and may witness or participate in settling the SRD. Cumulative SRD's are also computed for each shipper in order to identify trends. Any corrections to the receipt measurements can be made through an adjustment transaction. After approval of the receipt measurement and resolution of SRD's the seals are broken and the $\mathrm{PuO}_{2}$ cans are opened.

$\mathrm{UO}_{2}$ powder is received in sealed 55 gallon drums. The drums are weighed and stored until transfer to the $\mathrm{UO}_{2}$ hopper by pneumatic conveyor.

(iii) Shipments - All shipments of product or waste consist of discrete containers, each having a measured content of plutonium and an associated error. A shipment document (NRC 741) is prepared for each shipment that includes the limit of error. Product shipments usually are not measured on receipt. If they are, the measurement is generally nondestructive and SRD's can be resolved. Waste shipments generally have relatively large limitsof-error because of measurement difficulties. For recovery, special arrangements are generally made with the receiver to assure that his measurement capabilities are adequate and that large SRD's will not result. Shipments of waste for disposal are generally not measured on receipt.

(iv) Physical Inventory - Physical inventories are conducted 
in a dynamic fashion to avoid closing down plant operations. Physical inventories are conducted at least bimonthly but are usually conducted at approximately monthly intervals to correspond to a single plutonium isotopic compaign. The computerized accountability system, on-line and rapid measurement devices, and storage location monitors make it possible to conduct inventories on MBA's, sub-MBA's or the total plant at more frequent intervals such as each shift. However, these inventories are not cleanout inventories and large amounts of material are on inventory in the form of measured process hold-up. Section 17 (iv), Table 17-1, and Figures $17-2$ and 17-3 describe the inventory in more detail.

The inventory for uranium is performed at semiannual periods by combining the inventory of the mixed oxide with a cleanout inventory for uranium di un and bulk storage. The physical inventory of drums is performed by an item count and the uranium bulk storage hopper is cleaned out once during each six month period. The mixed oxide is analyzed for uranium and plutonium so that the uranium inventory on the mixed oxide is performed simultaneously with the plutonium inventory.

A dynamic cleanout inventory generally lasts 4-5 days and consists of approximately one day to identify all material that is in final measureable torm, three days to run the cleanout of the process, and one day to inventory material generated during the cleanout. The physical inventory is conducted in an automated manner using storage location monitors and in-line sensors to identify material. All monitors are checked and a computor record that they have been inventoried is made. Specific instructions and inventory cut-off dates are prepared by the Nuclear Material Safeguards 
Manager for each physical inventory. A random manual check of the reliability of all storage monitors by accountability personnel is routinely performed and is not a special part of the inventory procedure.

(v) Measured Discards and Retained Waste - Measured discards and retained waste are inventoried in a manner similar to other inventory material. Measured discards consist of shipments of solidified liquid waste and solid waste in 55 gallon barrels.

(vi) Operational Records and Acccunts - Records of receipts, removals and intemal transfers are maintained and kept for at least five (5) years on all special nuclear material. Material control is maintained through the use of computer transaction reports that are generated on file and in hard copy for each transaction.

A master transfer journal is printed out from the computerized data collection system at the close of each month which reflects contract description, plutonium isotopics, material code, date of transaction, 741 number, internal nuclear material transfer report number, plutonium content, source, and disposition.

All access to the computer system is controlled and maintained under supervision of the materials manager. The computer system assigns transaction numbers and checks the indentification of the user. Periodic audits are performed to assure that all transactions have been properly authorized. The identification and authorization system is redundant. Two identification symbols are required for access, e.g., a magnetic identification card and a fingerprint, and authorization is approved by verification that these symbols match the users name and by a verification that this name appears on an approved list for use of the terminal. 
NUCLEAR MATERIAL ACCOUNTANCY

27. Measurements, Measurement Control and Statistics

(i-v) Methods, Material Forms, and Errors - Key measurement points are identified on Figs, 14-13 and 14-14. Table 27-1 is a listing of each of the key measurements, the chemical and physical form of the material, the sampling and measurement methods, and the random and systematic errors for each measurement. These measurement methods are described in Appendix A.

(vi) Converting Source Data to Batch Data - Sampling and analysis by amperometric titration is used at a number of points to establish plutonium blend factors for each MBA and sub-MBA. Material entering and leaving the MBA or sub-MBA is weighed and the blend factor is assigned to determine the plutonium content. A new biend factor is established after a cleanout required because of a change in plutonium isotopics, a physical inventory, or if a significant change in the factor takes place. Blend factors are assigned to acceptable intermediate product, product, and clean scrap by multiplying the net weight of the material by the plutonium blend factor (the decimal equivalent of the weight percentage of plutonium in the material). The plutonium isotopic blend factor is also established by sampling, with analysis performed by either mass spectrometry or high-resolution gamma-ray spectrometry. The isotopic blend factor is averaged over the entire process and applied uniformly at each MBA. The sampling plan used for establishing factors is sampling of material at each measurement point at least once each shift (approximately equivalent to at least one sample per subblend of macerial) at randomly selected times. 
Table 27-1. Summary of Plutonium and Uranium Measurement Methods

\begin{tabular}{|c|c|c|c|c|c|c|}
\hline \multirow{2}{*}{ 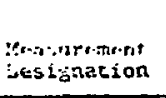 } & \multirow{2}{*}{$\begin{array}{l}\text { Maricinal } \\
\text { Éorm }\end{array}$} & \multirow[b]{2}{*}{ Merhod } & \multirow[b]{2}{*}{ Range } & \multicolumn{2}{|c|}{$20(\%)$} & \multirow[b]{2}{*}{ Consents } \\
\hline & & & & Random & Syscematic & \\
\hline WL & $\begin{array}{l}\text { rowder in bulk } \\
\text { Scorage Vessels and } \\
\text { Weiph inppres }\end{array}$ & Welght & $20-3000 \mathrm{~kg}$ & 0.14 & 0.03 & 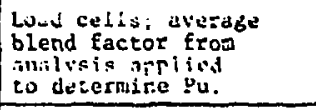 \\
\hline$w / 2$ & Containcrs & Wcight & $3-300 \mathrm{~kg}$ & 0.16 & 0.06 & 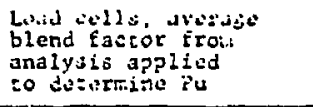 \\
\hline sl & $\mathrm{PuO}_{2}$ & Amperonetric Titration & $-\cdot$ & 0.50 & 0.10 & $\begin{array}{l}\text { Hecults puoled co } \\
\text { determine average } \\
\text { factor }\end{array}$ \\
\hline A2 & $\mathrm{XO}_{2}(\mathrm{Pt})$ & Anperomecric Titration & -- & 0.60 & 0.16 & $\begin{array}{l}\text { Resulis pooled to } \\
\text { determine averabie } \\
\text { factor }\end{array}$ \\
\hline Si & Powder in Cans & Core (Manual) & $\cdots$ & 0.20 & 0 & \\
\hline$\equiv 2$ & $\begin{array}{l}\text { Powdcr in Eulk } \\
\text { Storage }\end{array}$ & $\begin{array}{l}\text { Mlending/Thiof } \\
\text { Mechanical }\end{array}$ & -- & 0.2 & 0 & \\
\hline 53 & Pellets & $\begin{array}{l}\text { Grab/Random } \\
\text { (Mechanical) }\end{array}$ & -- & 0.2 & 0 & $\begin{array}{l}\text { Sotin pellecs sampied } \\
\text { masualiy }\end{array}$ \\
\hline 8 & Linuid & Mixing/Thief (Manun1) & 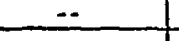 & 0.2 & 0 & \\
\hline$\because 1$ & $\begin{array}{l}\mathrm{PuO}_{2} \text { in } \mathrm{L}-10 \\
\text { Containers }\end{array}$ & Decay Gainta & $5 \mathrm{~kg} \mathrm{Pu}$ & 20 & 20 & $\begin{array}{l}\text { Course check on }{ }^{239} \mathrm{Pu} \\
\text { inconing Pu }\end{array}$ \\
\hline .2 & $\mathrm{PuO}_{2}$ in Caris & Calorimetry & $2.5 \mathrm{~kg} \mathrm{Pu}$ & 4 & 4 & Pu Isosopies by cianines \\
\hline$\because 3$ & ruel Rods & $\begin{array}{l}\text { Induced Fission } \\
\text { Gamma }\end{array}$ & $100 \mathrm{~B} \mathrm{Pu}$ & 1 & 1 & Koj Scanner $\left(100^{\circ}\right)$ \\
\hline$\because 4$ & Aralycical Samples & Decay Gamma & $1-10 \mathrm{~g} P \mathrm{Pu}$ & $2-10$ & $2-4$ & \\
\hline$\therefore 5$ & $\begin{array}{l}\text { Dircy Scrap in } \\
\text { 1-teitce Cuns }\end{array}$ & $\begin{array}{l}\text { Spontaneous Fission } \\
\text { Meutrons }\end{array}$ & $150 \mathrm{~g} \mathrm{Pu}$ & $\begin{array}{r}10 \\
5 \\
\end{array}$ & $\begin{array}{l}10 \\
10 \\
\end{array}$ & $\begin{array}{l}\text { Infue to NWT } \\
\text { Output from inT }\end{array}$ \\
\hline$\because 6$ & $\begin{array}{l}\text { 5olid hiusice in } \\
\text { l-Gallon Cans }\end{array}$ & Jecay Gamela & $-10 \mathrm{gPu}$ & $\begin{array}{l}20 \\
10 \\
\end{array}$ & $\begin{array}{l}25 \\
10 \\
\end{array}$ & $\begin{array}{l}\text { Nevilu Density } \\
\text { Low Density }\end{array}$ \\
\hline$: 77$ & 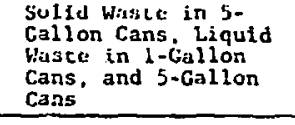 & Decay Carmma & $=10 \mathrm{gPu}$ & 20 & 10 & \\
\hline$\because 0$ & $\begin{array}{l}\text { Waste in 55-gallon } \\
\text { Druirs }\end{array}$ & Decay Carma & $<100 \mathrm{~g} \mathrm{Pu}$ & $\begin{array}{l}20 \\
35\end{array}$ & $\begin{array}{l}40 \\
50\end{array}$ & $\begin{array}{l}\text { Low Density } \\
\text { Mediun Densicy }\end{array}$ \\
\hline $\mathbf{H}$ & $\begin{array}{l}\text { Hold up on Plpe and } \\
\text { Container Walls }\end{array}$ & $\begin{array}{l}\text { Spontaneous Fission } \\
\text { feutrons }\end{array}$ & $0.1-3 \mathrm{~kg} \quad \mathrm{Pu}$ & 20 & 50 & \\
\hline A3 & $\mathrm{UO}_{2}$ & Gravimetry & $\cdots$ & $.06 \%$ & $.10 \%$ & \\
\hline A4 & $\mathrm{MO}_{2}$ (J) & Dichromate Titration & - & .347 & .107 & $\begin{array}{l}\text { Results pooled to deter } \\
\text { mire average factor }\end{array}$ \\
\hline
\end{tabular}


The exception to the use of element factors is the assignment of plutonium mass by nondestructive assay (NDA). NDA is used at the receiving station on L-10 containers to obtain a quick measurement of plutonium content and isotopic composition without opening the container. NDA is again applied to each can of $\mathrm{PuO}_{2}$ removed from the $\mathrm{L}-10$ containers to obtain both plutonium content and isotopic composition. Plutonium isotopics are measured by high resolution gammaray spectrometry in both cases. NDA is applied to all final fuel rods by using a rod scanner to measure fissile mass and the average plutonium isotopic blend factor to convert fissile mass to plutonium mass. The plutonium mass of dirty scrap and waste is also measured by NDA in combination with the use of the average blend isotopic factor. The latter NDA methods measure the content of one or more plutonium isotopes only and therefor the isotopic composition is used to convert to total plutonium.

(vii-ix) Measurement Controls - All measurement methods are calibrated relative to standards ultimately traceable to national standard materials. These calibrations are performed frequently to assure accuracy and and meet financial and regulatory requirements. A program of control standards is used to monitor the performance of all measurement methods and to provide a data base for quantifying the errors in the methods. Results of the measurement of control standards are compared with control limits established for each method and, if performance is below acceptable standards, action such as recalibration is taken prior to resuming measurements. 
Weight - Weighing scales for individual containers are calibrated using standard weights. Calibrations are checked at least once each shift and standards at six-month intervals.

Load cells for weighing bulk storage vessels are calibrated using artifact standards. Calibrations require interruption of processing and are, therefore, conducted at six-month intervals unless results from the control program indicate a recalibration is required. Calibrations are checked at least once each shift by attaching standard weights to the load cells.

Plutonium Factors - Amperometric titration is calibrated with NBS*standard 949 plutonium metal daily. Control checks using a standard solution are made each shift and are compared to preset limits.

Plutonium Isotopic Composition Factors - Mass spectrometry is calibrated with NBS standards 948 , 947, and 946. Calibration is performed daily. Pu-238 content is determined by $\alpha$-particle spectrometzy and is calibrated relative to a $\mathrm{Pu}-239$ standard source daily. High resolution gamma-ray spectrometry is calibrated directly relative to NBS 948,947 , and 946 for small samples and relative to mass and $\alpha$-particle spectrometry through synthetic standards for large samples. All isotopic measurement methods are checked each shift prior to operation and compared with control limits.

Nondestructive Assay - NDA methods are calibrated using synthetic standards prepared to closely duplicate the unknowns with respect to all critical parameters. The plutonium content of the standard is determined by chemical analysis and weighing of the source material and is traceable to national standards 
in this manner. Calorimetry is calibrated using both national electrical standards and Pu-238 standard power sources. AII NDA methods are checked every four hours using reliable working standards and results are compared to preset limits.

(x) Statistics - Measurement control data on standards are analyzed to determine:

(a) the mean result.

$$
\bar{x}=\frac{\sum_{i=1}^{n} x_{i}}{n} \text {, and }
$$

(b) the variance in the mean,

$$
\operatorname{var}(\bar{x})=\frac{\sum_{i=1}^{n}\left(x_{i}-\bar{x}\right)^{2}}{n-1} .
$$

The bias, $b$, is then estimated by:

$$
\mathrm{b}=\overline{\mathrm{x}}-\mu,
$$

where $\mu$ is the known value of the standard. The random error standard deviation, $S_{r}$, is

$$
S_{r}(\bar{x})=[\operatorname{var}(\bar{x})]^{1 / 2} \text {. }
$$

The random error coefficient of variation, $\Delta(x)$ is estimated by:

$$
\Delta_{r}(\bar{x})=s_{r}(\bar{x}) / \bar{x}
$$

The systematic error standard deviation, $\mathrm{S}_{\mathbf{s}}$, is estimated by 


$$
s_{s}(\bar{x})=\left[\frac{\operatorname{var}(\bar{x})}{n}+\left.s_{0}^{2}\right|^{1 / 2}\right.
$$

where $s_{0}^{2}=$ variance in the content of the standard. The coefficient of variation is given by

$$
s_{s}(\bar{x})=\frac{s_{s}(\bar{x})}{\bar{x}}
$$

This estimate of the systematic error is justified because the bias correction is always made.

For the analytical methods and NDA, the standards data are also grouped by the collowing criteria:

analyst (analytical methods only) calibration period, and shift.

These data are analyzed by analysis of variance to detect significant trends, i.e., short-term systematic errors among groups.

The sampling error for factors is determined by computing the variance in the data pooled to determine a blend factor and subtracting the analytical random error variance.

The calibration error variance $S_{0}^{2}$ for INA is determined from analysis of the calibration relationship fit to the calibration data rather than the error in the mass of the standards.* The equation used for the systematic error is:

* The error in the mass is used in weighting each calibration point. 


$$
\Delta_{s}(\bar{x})=\left[\frac{\operatorname{var}(\bar{x}) / n}{\bar{x}}+\frac{\sum_{i}\left\{s_{i}^{2}(N D A)\right\}}{\left\{\sum_{i} m_{i}(N D A)\right\}^{2}}\right]^{1 / 2}
$$

where $S_{i}$ (NDA) and $m_{i}$ (NDA) are the calibration error standard deviation and mass for each NDA measurement, i.e., $s_{i}$ (NDA) is the NDA calibration error standard deviation in $m_{i}$ (NDA) and is predicted using the uncertainties in the calibration constants.

Control limits are set at the $95 \%$ confidence level and at the $99 \%$ corfidence level. If the $95 \%$ C.L. is exceeded, the method is closely monitored to prevent further degradation. If the $99 \%$ C.L. is exceeded, the method is taken out of service until corrections can be made to bring results back within limits.

Measurement control data is entered into the computer accounting system immediately and tests relative to control limits are performed. The measurement control data base is then updated to reflect the current performance of each method. The data in the data base are weighted according to the time acquired. The most recent data group (usually 15-25 data points) is assigned a weight of unity. The previous data group is assigned a weight of $1 / 2$, the next group a weight of $1 / 4$, etc. No data older than four months is pooled for computing measurement performance.

28. Overal1 Limits of Error

(i) Model - Measurement data for each measured quantity of material include the following: 
Identification Code of Material or Item

Measured Result (Bias Corrected) for total plutonium as well as the bulk quantity and plutonium factor or NDA and plutonium isotopic factor.

Random Error for total plutonium.

Systematic Error for total plutonium as well as component systematic errors from bulk and plutonium factor or NDA and isotopic factor.

Measurement Code for bulk and plutonium factor or for NDA and isotopic factor.

The computerized accounting system is used to correct all measured results for bias before they are stored or reported and to assign the current estimate of the random and systematic errors to the measured value as well as a measurement code that can be used to identify items with covariant errors.

The overall limit of error on a sum or difference of items is then calculated in the following way using an additive model:

Let

$$
m=\sum_{i=1}^{n}\left( \pm m_{i}\right)
$$

Then

$$
\begin{aligned}
L E(m) & =2\left\{\sum_{i=1}^{n} s_{R}^{2}\left(m_{i}\right)+\sum_{i=1}^{n} s_{s}^{2}\left(m_{i}\right)\right. \\
& +2 \sum_{i=1}^{n} \sum_{j>i}^{n}\left[ \pm s_{s}^{b}\left(m_{i}\right) s_{s}^{b}\left(m_{j}\right) \pm s_{s}^{e}\left(m_{i}\right) s_{s}^{e}\left(m_{j}\right)\right. \\
& \left. \pm s_{s}^{i}\left(m_{i}\right) s_{s}^{i}\left(m_{j}\right)\right] \mid 1 / 2,
\end{aligned}
$$


where

$$
\begin{aligned}
& S_{R}\left(m_{i}\right)=\begin{array}{l}
\text { total random error standard } \\
\text { deviation in plutonium mass, }
\end{array} \\
& \mathbf{m}_{i} \text { ' } \\
& S_{s}\left(m_{i}\right)=\begin{array}{l}
\text { total systematic error standard } \\
\text { deviation in plutonium mass, } m_{i}
\end{array} \\
& s_{s}^{b}, s_{s}^{e}, s_{s}^{i}\left(m_{i}\right)=\text { the bulk or NDA(b), element } \\
& \text { tor (i) systematic error } \\
& \text { standard deviation in plu- } \\
& \text { tonium mass, } \mathbf{m}_{i} \text {, }
\end{aligned}
$$

and where the ( $t)$ is the sign of the product of the signs of the masses of $m_{i}$ and $m_{j}$.

The final double summation above corrects the overall LE(m) for covariance between masses measured on the same scale or the same NDA instrument, or having the same element or isotopic composition factor. The computer accounting system limit of error program first computes the total random and systematic errors for all masses in the sum or difference, neglecting for the moment covariance. The program then corrects for covariance by selecting the bulk component systematic error for the first mass, $m_{i}$, and searching all other masses for similar measurement codes. If a similar code is found the errors are multiplied and twice the result added or subtracted to the total error. The search continues by next selecting the element factor component systemaiic error for mass $m_{i}$ if the bulk measurement was weight or volume, or the isotopic factor systematic error for mass $m_{i}$ if the measurement was NDA. Al1 the other masses are searched for similar codes as discussed above. The process is repeated for each mass in the sum or difference until all covariant error pairs have been accounted for. 
(1i)

S/R Differences - The limit of exror of the receipt of $\mathrm{PuO}_{2}$ or the shipment of fuel rods, scrap. or waste is computed as in (i) above for a sum of terms. The limit of error for the shipper-receiver difference is then calculated from:

where

$$
\mathrm{LE}(\mathrm{SRD})=\left|L E^{2}(s)+L E^{2}(R)\right|^{1 / 2}
$$

$$
\begin{aligned}
& \mathrm{LE}(S)=\text { shipper } \mathrm{LE} \\
& \mathrm{LE}(\mathrm{R})=\text { receiver } \mathrm{LE}
\end{aligned}
$$

If the shipper LE is unknown, then the LE in the difference is estimated to be:

$$
\operatorname{LE}(S R D)=2 \operatorname{LE}(R)
$$

(iii) Inventory - The inventory is a sum of terms and the total LE is calculated as described in (i).

(iv) MUF - The MUF is computed from the following components :

$$
M U F=B I+R-S-E I
$$

where

$$
\begin{aligned}
B I & =\text { beginning inventory } \\
E I & =\text { ending inventory } \\
R & =\text { receipts } \\
S & =\text { shipments. }
\end{aligned}
$$

The MUF is computed by substituting the individual component terms for each category of material in the equation, i.e., BI, EI, R, and S.' Common terms are cancelled, i.e., items* appearing in more than one sategory

* An item is a container of material having a unique identification code. 
with a different sign cancel in the above equation. The LE of this sum and difference of terms is then calculate $i$ according to the model (i) above. The relative $L E(M U F)$ is calculated by dividing the LE(MUF) by the larger of receipts or shipments. 


\section{APPENDIX A}

$\mathrm{MO}_{2}$ FABRICATION PLANT MEASUREMENT METHODS

W1 Load Cells for Bulk Storage Weighing - Load cells are used for weighing $\mathrm{PuO}_{2}$, recycle $\mathrm{MO}_{2}$, and $\mathrm{MO}_{2}$ storage vessels and have $1,000 \mathrm{~kg}, 500 \mathrm{~kg}$, and $3,000 \mathrm{~kg}$ capacities, respectively, and sensitivities of 100 grams. The storage vessels have flexible pipe couplings and have a direct link to the computer accounting system. Weigh hoppers used to weigh out the proper mix of $\mathrm{PuO}_{2}, \mathrm{UO}_{2}$ and recycle $\mathrm{MO}_{2}$ have capacities of $200 \mathrm{~kg}$, $400 \mathrm{~kg}$, and $50 \mathrm{~kg}$.

A1,A2 Amperometric Titration - This method is applicable to the determination of plutonium in plutonium oxide, mixed plutonium and uranium oxide, and liquid nitrate solutions. The plutonium in $0.5 \mathrm{~N} \mathrm{H}_{2} \mathrm{SO}_{4}$ is oxidized to the hexavalent state with $\mathrm{Ag}$ (II) oxide, adjusted to $5 \mathrm{~N}$ $\mathrm{H}_{2} \mathrm{SO}_{4}$, and titrated with standard ferrous ammonium sulfate. The end point is detected amperometrically.

A3 Gravimetric - This method is applicable to the determination of uranium in uranium oxides and uranyl nitrate solution. The material is converted to $\mathrm{U}_{3} \mathrm{O}_{8}$ by ignition and the uranium concentration is calculated from the gravimetric-conversion data. Nonvolatile impurities are determined by emission spectrography.

A4 Dichromate Titration - This method is readily applicable to analysis for uranium in mixed $\mathrm{PuO}_{2}-\mathrm{UO}_{2}$ fuel without separation because plutonium does not interfere. Ferrous sulfate is used to reduce $U(V I)$ to $U$ (IV) in a concentrated phosphoric acid medium containing sulfarnic acid. The excess ferrous ion is oxidized by nitric acid with Mo(VI) 
as a catalyst. Dilute sulfuric acid containing $V$ (IV) is added and the solution is titrated to a potentiometric end point with standard potassium dichromate.

S1 Core (Manual) Sampling - The sampler consists of an outer sheath with an auger bit turning within the sheath. This bit is turned by hand or an electric drill. Three to six cores are extracted from each container sampled.

S2

Blending/Thief (Mechanical) Sampling - Powder in blending vessels is sampled by pneumatically extracting powder through a sampling tube, re-blending, and repeating the sampling.

S3 Grab/Random (Mechanical) Sampling - A random number generator is used to select pellets from pellet boats and trays.

S4 Mixing/Thief (Mechanica1) Liquid Sampling - The solution is mixed and the liquid is sampled using a vacuum thief tube inserted to different depths in the liquid.

N1 Decay Gamma Assay for ${ }^{239} \mathrm{Pu}$ in L-10 Container - This is the first nuclear measurement performed on the input material to the $\mathrm{MO}_{2}$ plant. The $\mathrm{L}-10$ container unloaded off the truck is assayed for ${ }^{239} \mathrm{Pu}$ on the loading dock using the "385" $\mathrm{keV}$ complex of gamma rays as a signature for ${ }^{239} \mathrm{Pu}$. The detector used is a stabilized $\mathrm{NaI}$ (T1) detector viewing a rotating $\mathrm{L}-10$ container in a configuration similar to the one shown in Fig. A-1.

N2 High Resolution Gamma Spectroscopy of $\mathrm{Pu}$ in a $\mathrm{PuO}_{2}$ Can to Determine Pu Isotopics Followed by a Calorimetric Assay of the Can - This station combines two highly accurate measurements which lead to an accurate 


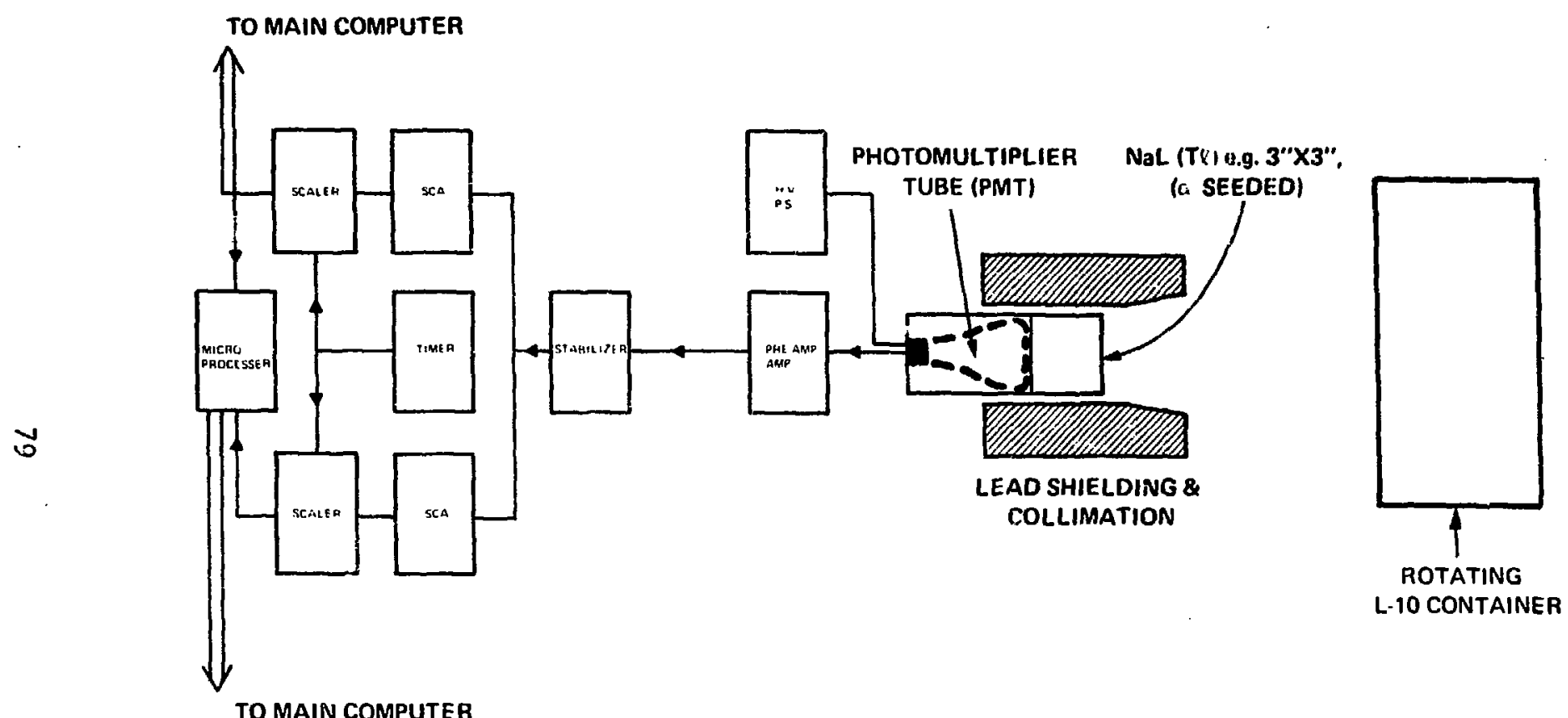

TO MAIN COMPUTER

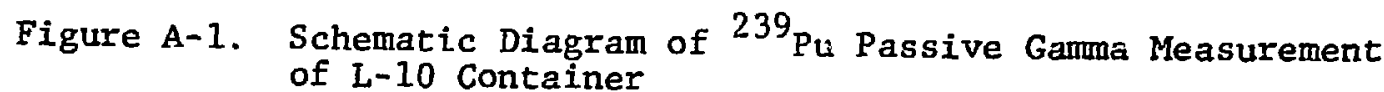


determination of the total fissile and total $\mathrm{Pu}$ content at the input stage. This is the primary plant input measurement and is applied to $1.00 \%$ of the $\mathrm{Pu}$ entering the plant. Following removal from the L-10 container, the $\mathrm{PuO}_{2}$ cans are automatically subjected to the following series of successive measurements:

- Identification

- Weighing

- Isotopic Determination

- Calorimetric Determination

Upon discharge from the calorimeter, the $\mathrm{PuO}_{2}$ content of the can is transferred pneumatically into a $\mathrm{PuO}_{2}$ storage vessel.

The NDA isotopic determination proposed here provides an average of the isotopics of the $\mathrm{Pu}$ in the sealed can. It can be directly compared with the shippex isotopics and later on with the isotopics determined in the plant analytical laboratory (ASF).

The isotopic measuring technique is based on high resolution gamma spectroscopy employing a Ge(Li) detector and a sophisticated progranmable pulse height analyzer (PHA). The pulse height information is collected over a narrow energy band of decay gamma-rays and $\mathrm{x}$-rays around $100 \mathrm{keV}$ where all $\mathrm{Pu}$ isotopes, except ${ }^{242} \mathrm{Pu}$, contribute. Measuring time is on the order of an hour.

The calorimetry is a measurement of the thermal power from plutonium that is converted directly to plutonium mass using the relative abundance of each plutonium isotope and Americium -241. A large portion of the heat generation in the $\mathrm{PuO}_{2}$ powder is due to the minor isotope ${ }^{238} \mathrm{Pu}$, which is present with concentrations of $1 \%$ to $3 \%$. Components used in a typical calorimeter system are shown in Fig. A-2. The length 


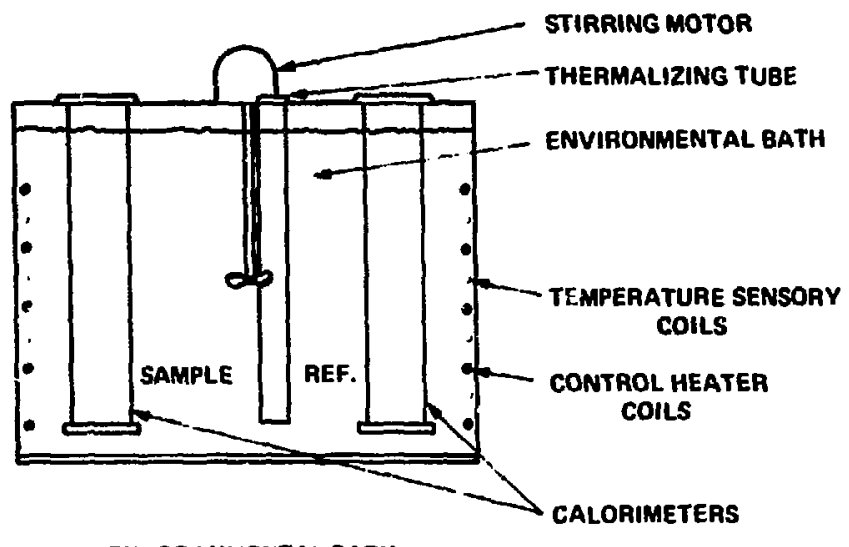

ENVORONMENTAL BATH

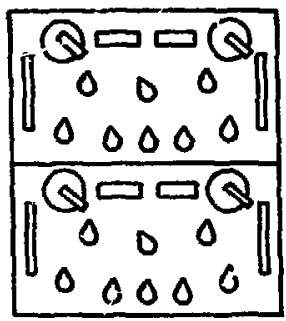

CALORIMETER CONTROL PANELS

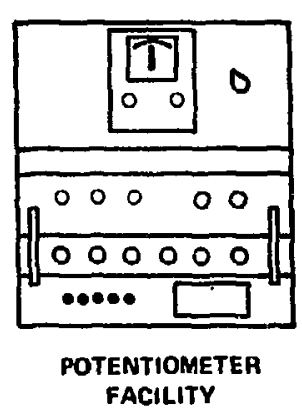

CONT ROL PANELS

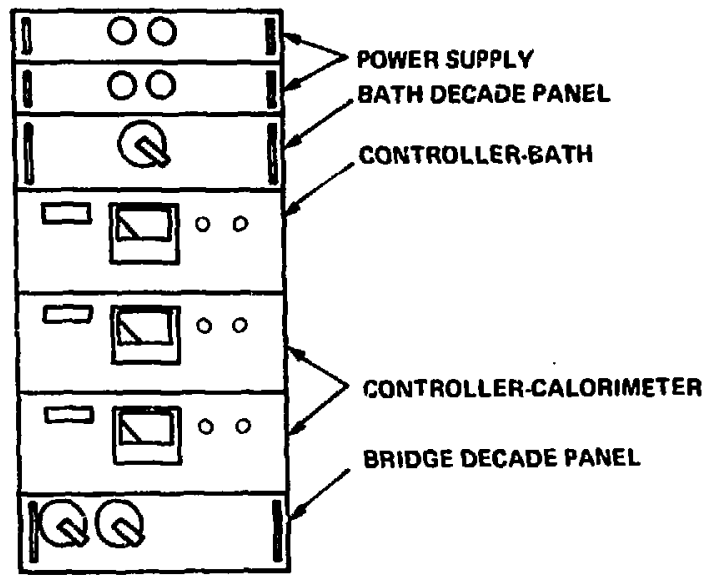

Figure A-2. Components Used in a Typical Isothermal Calorimeter System 
of time required for a calorimeter measurement is dictaced by the slow process of achieving thermal equilibrium. Typically $1-\frac{1}{2}$ to 1 hour is required to come within $0.1 \%$ of equilibrium because servo control of the temperature of the calorimeter chamber is used.

Total and Pellet-by-Pellet Fissile Content Fuel

Rod Scanner - The purpose of this assay station is to accurately measure the total fissile content of the finished mixed oxide fuel rod, and to provide information on the distribution of the pellet-by-pellet fissile content along the rod length.

The assay technique is based on the ${ }^{252}$ cf active/ passive assay system that utilizes both active and passive techniques for the measurement of fissile content and pellet-to-pellet uniformity in mixed :xide fuel rods. For the active portion of the measurement, a $0.5-1.5 \mathrm{mg}{ }^{252} \mathrm{Cf}$ neutron source is used to interrogate the fuel rods. The source is positioned at or near the center of a moderator and the fuel rods are moved past the source and into a gamma-ray detector. The total fissile content is then determined by counting the highenergy delayed gamma-rays resulting from the induced fission reactions, using a 5 in. diam. NaI detector with a through-hole for the passage of the fuel rods, positioned near the output side of the ${ }^{252} \mathrm{Cf}$ shield as shown in Fig. A-3.

The pellet-to-pellet uniformity is determined by counting the more intense lower-energy passive ganmarays from the fuel using the background NaI detectors. The rod scan speed of about $2 \mathrm{~cm} / \mathrm{sec}$ complys with the expected throughput of the $\mathrm{MO}_{2}$ plant ( $13 \mathrm{rods} / \mathrm{hr}$ ). An increase in the expected throughput will require a dial channel rod scanner using a single ${ }^{252} \mathrm{Cf}$ source and allowing simultaneous scanning of two fuel rods. 


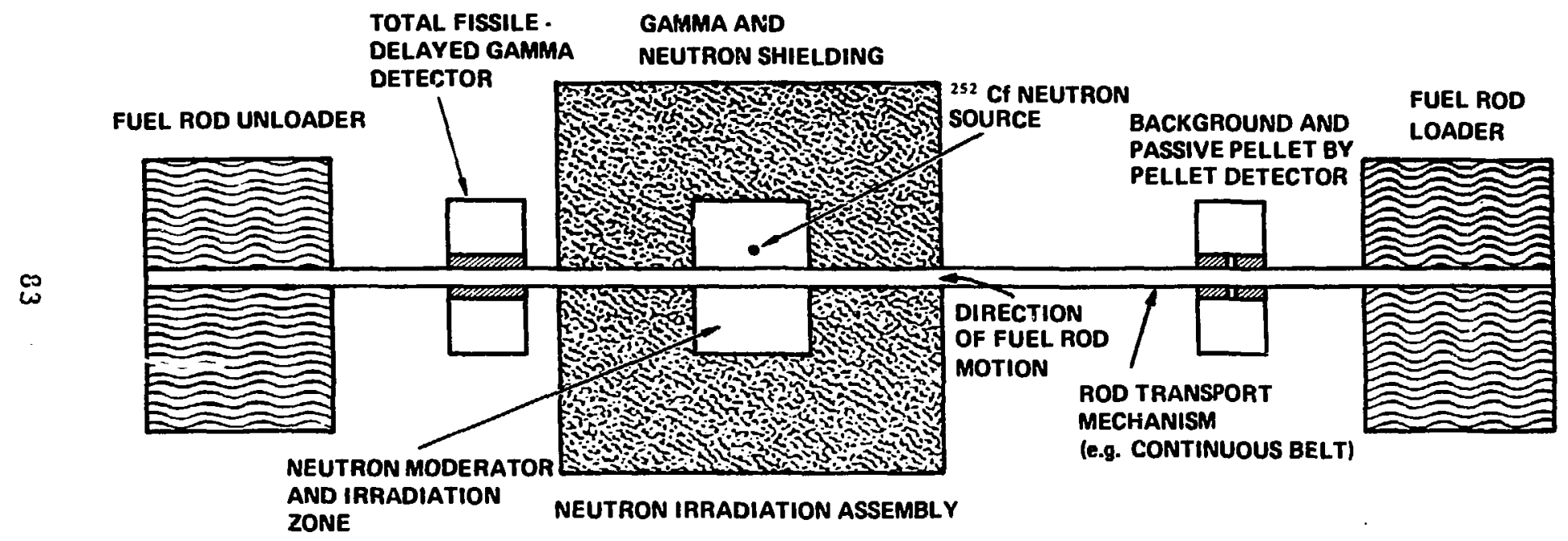

Figure A-3. Schematic Layout for a Mixed Oxide Rod Scanner 
$\mathbf{N 4}$

Passive Smal1 Sample Assay Systems for ${ }^{239} \mathrm{Pu}$, ${ }^{241} \mathrm{Pu}$ and ${ }^{238} \mathrm{U}$ - The main purpose of this station is to perform assays for the different $\mathrm{Pu}$ isotopes and ${ }^{238} \mathrm{U}$, in samples sent to the analytical services facility (ASF). Since the samples are small (several grams of $\mathrm{PuO}_{2}$ or $\mathrm{MO}_{2}$ or single sintered pellets), the method is a passive gamma assay. The assays are based on measurement of the "385 keV" complex of $239 \mathrm{Pu}$, the $208 \mathrm{keV}$ line of ${ }^{241} \mathrm{Pu}$, and the $766 \mathrm{keV}$ and $1001 \mathrm{keV}$ lines of ${ }^{238} \mathrm{U}$ from thin "absorption-less" samples of $\mathrm{PuO}_{2}$ and $\mathrm{MO}_{2}$ powder. The ratio of ${ }^{239} \mathrm{Pu}$ to ${ }^{238} \mathrm{Pu}$ provides the $\mathrm{MO}_{2}$ plant with very valueble data on the mixing process.

A schematic diagram of the nuclear detection part of the sampling system is similar to the one shown in Fig. A-4. The main feature of this system is a high efficiency NaI(TI) well counter. The accurately weighed sample vials are placed into the detector well by an automatic sample changer. The $\mathrm{PuO}_{2}$ and $\mathrm{MO}_{2}$ sample weights are limited to around $1 \mathrm{gram}$, in order to minimize tha self-shielding correction. The measuring time is 5-10 minutes. When $\mathrm{MO}_{2}$ pellets are measured, the self attenuation effect is corrected for by using wellknown standard pellets.

Spontaneous Fission and Decay Gamma Assay for

Pu in 1 Liter Containers of Dirty Scrap - The purpose of this station is to measure the incoming, dirty scrap containers and the outgoing containers (after homogenization of the material) at the MWT. The assay method used is a measurement of spontaneous neutron fission rate (due primarily to ${ }^{240} \mathrm{Pu}$ and ${ }^{242} \mathrm{Pu}$ ) using a Fission Multiplicity Detector supplemented by a passive gamma assay for the "385 keV" complex of ${ }^{239} \mathrm{Pu}$. The use of fast neutrons and high energy gamma rays results in a substantial reduction of the matrix effect. The same apparatus is used for both intput and output measurements. 


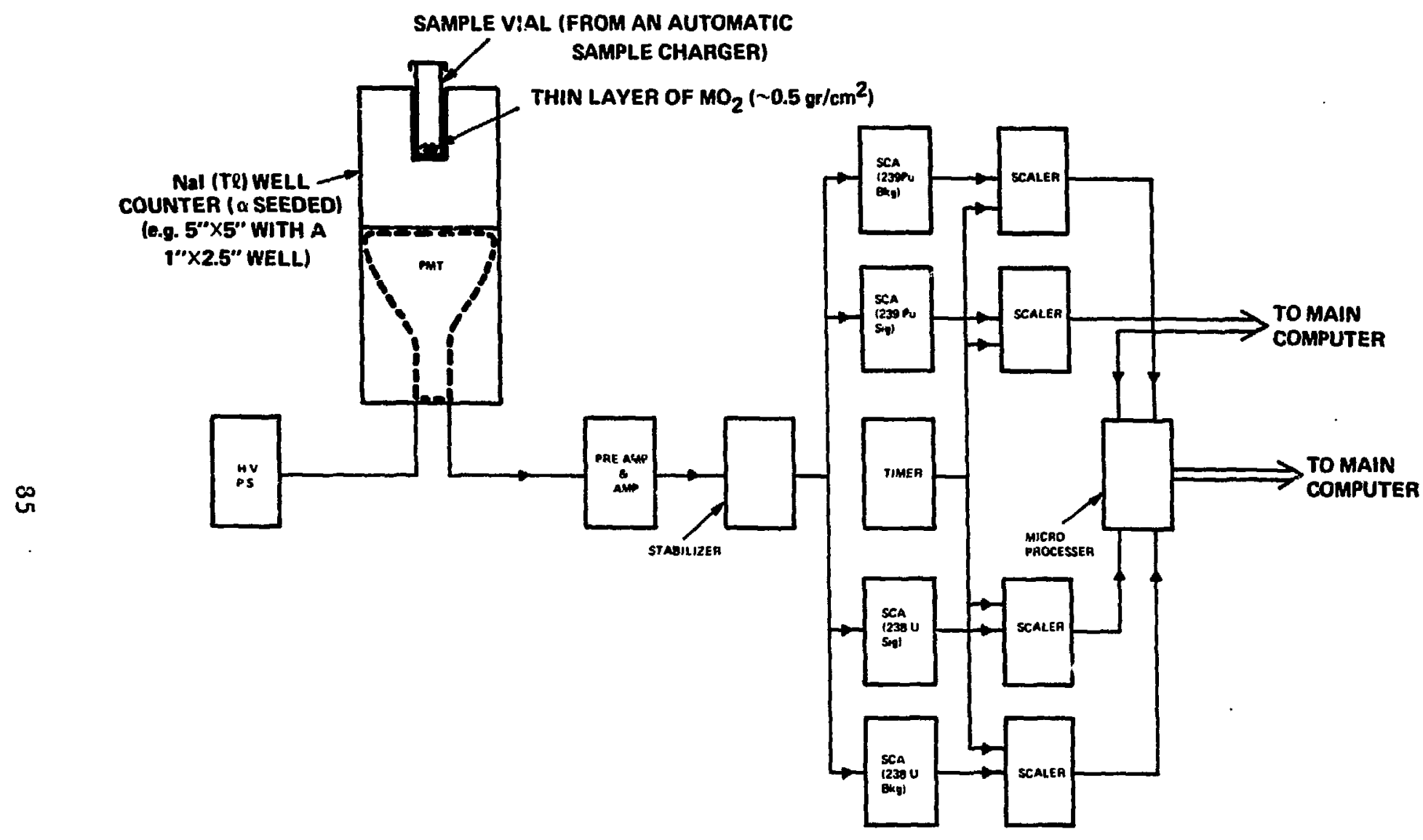

Figure A-4. Schematic Diagram of ${ }^{239} \mathrm{Pu}$ and ${ }^{238} \mathrm{U}$ Passive Small Assay System 
The spontaneous fission rate is dominated by
$240 \mathrm{Pu}$ and $242 \mathrm{Pu}$. The conversion the total fissile content, or into the content of each $\mathrm{Pu}$ isotope, requires the knowledge of the isotopic ratio. The spontaneous fission process and its signature is very complex, hence a sophisticated diversion attempt to produce the same fission rate with less plutonium is implausible.

The system for performing the measurements of the above mentioned signatures is shown in Fig. A-5. The container rotates at the center of the FMD. The FMD detectors consist of long fast neutron and gamma detectors. The response of these detectors is very fast (a new nanoseconds) and it allows the use of very short coincidence time gates. Consequently, the number of chance coincidences produced primarily by $(\alpha, n)$ neutrons and those due to intermediate and high energy gamma rays are small. The hydrogenous fast scintillator is decoupled from the plutonium bearing container by a layer of $\mathrm{B}_{4} \mathrm{C}$. A lead shield is interposed behind the $\mathrm{B}_{4} \mathrm{C}$ in order to harden the detected prompt gamma spectrum.

The electronic circuit consists of a fast discriminator and $\mathrm{N}$-fold majority coincidence unit ( $N$ is the number of individual scintillators used) which allows one to record various levels of coincidences, $M_{1}$ out of $N$, down to $1 / \mathrm{N}$. The latter is very closely related to the sum of the single count-rates of the individual scintillators. An electronic processor analyzes the data to yinld the measured fission rate and its uncertainty. Using previously measured isotopic ratios, the amount of each $\mathrm{Pu}$ isotope and the totel fissile content can alsc be calculated by the processor. 


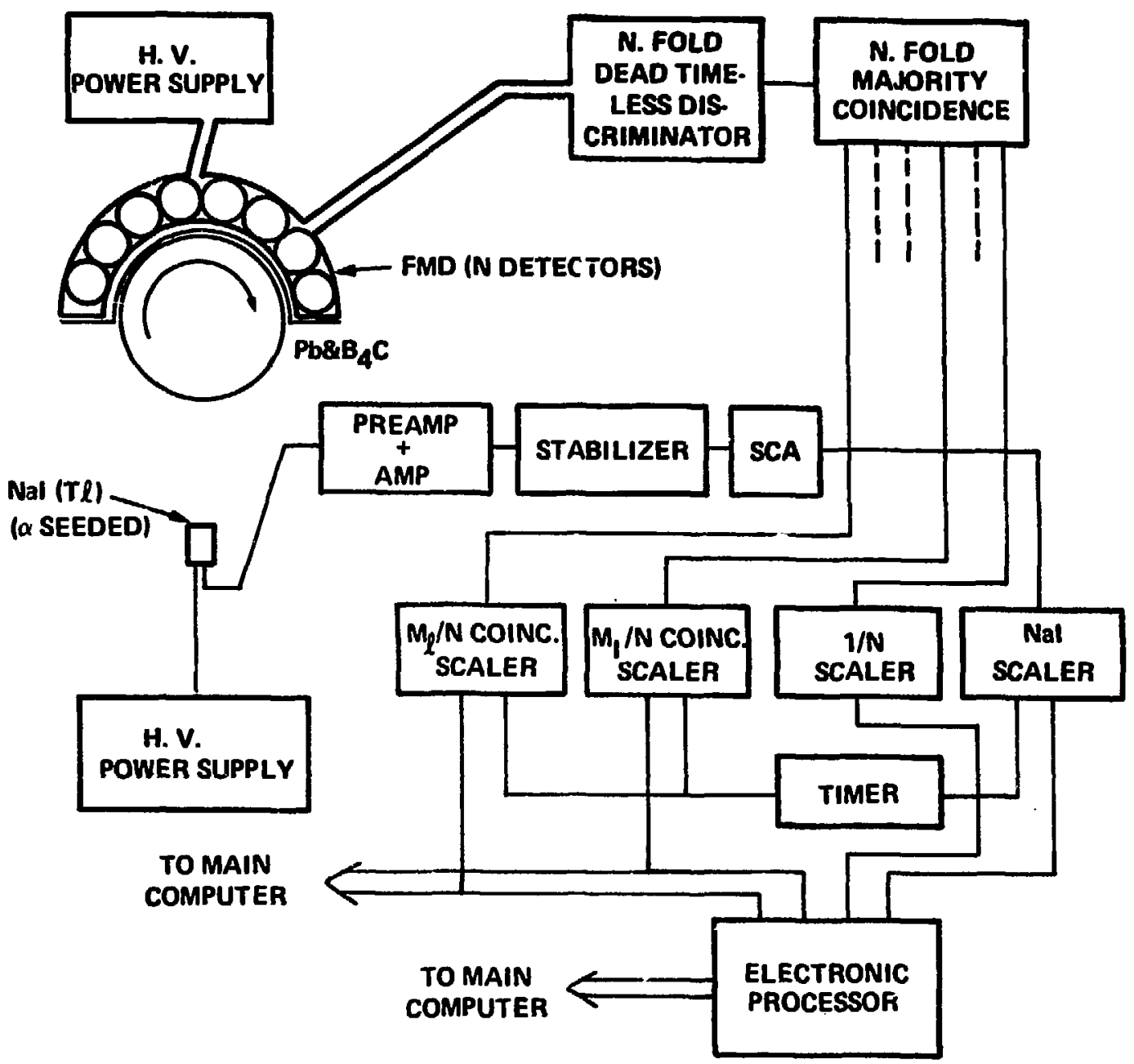

Figure A-5. Fission Multiplicity Detector (FMD) for Detection of Sporttaneous Fission Rate - Block Diagram of Electronic Logic 
The neutron and the higher energy gamma (e.g., $\mathrm{Er} \geq 1 \mathrm{MeV}$ ) self shielding effect in the $\mathrm{PuO}_{2}$ cans is rather small and can be further reduced by taking proper ratios of multiplicity functions.

N6 - Decay Gamma Assay for ${ }^{237} \mathrm{Pu}$ in 1-Gallon Solid Waste Containers

N7 - Decay Gamma Assay for ${ }^{237} \mathrm{Pu}$ in the Following Containers:

5 gallon solid waste container at the MWT output 1 gallon liquid waste container at the MWT input 5 gallon liquid waste container at $t:=$ LWT input

N8 - Decay Gamma Assay for ${ }^{239} \mathrm{Pu}$ in 55 Gallon Drum A11 these stations (N6, N7, and N8) use the same nuclear technique to measure the amount of $\mathrm{Pu}$ that may be present in the various forms of the waste. The nuclear method is the passive detection of the decay gamma radiation from ${ }^{239} \mathrm{Pu}$ (i.e., the "385" keV complex) using a stabilized $\mathrm{NaI}(\mathrm{T} 1)$ detector viewing a rotating waste container.

H - Holdup Residue Measi rements - The purpose of these measurements is to determine the $\mathrm{Pu}$ content of the holdup residue before and after cleanout of the system. The holdup residue is made of feed or product that coat the walls of the containers and of the pipes leading to them. The amount of material held up in this fashion can be quite substantial. The measuremert uses a neutron detector system with a properly designed hydrogeneous reflector to obtain a reasonably uniform response from the fast neutrons emitted by the Pu bearing materials. Because of the relatively large amount of material involved, the neutron emission is substantial and the count rate is sufficiently high to allow attainment of high statistical accuracy. 